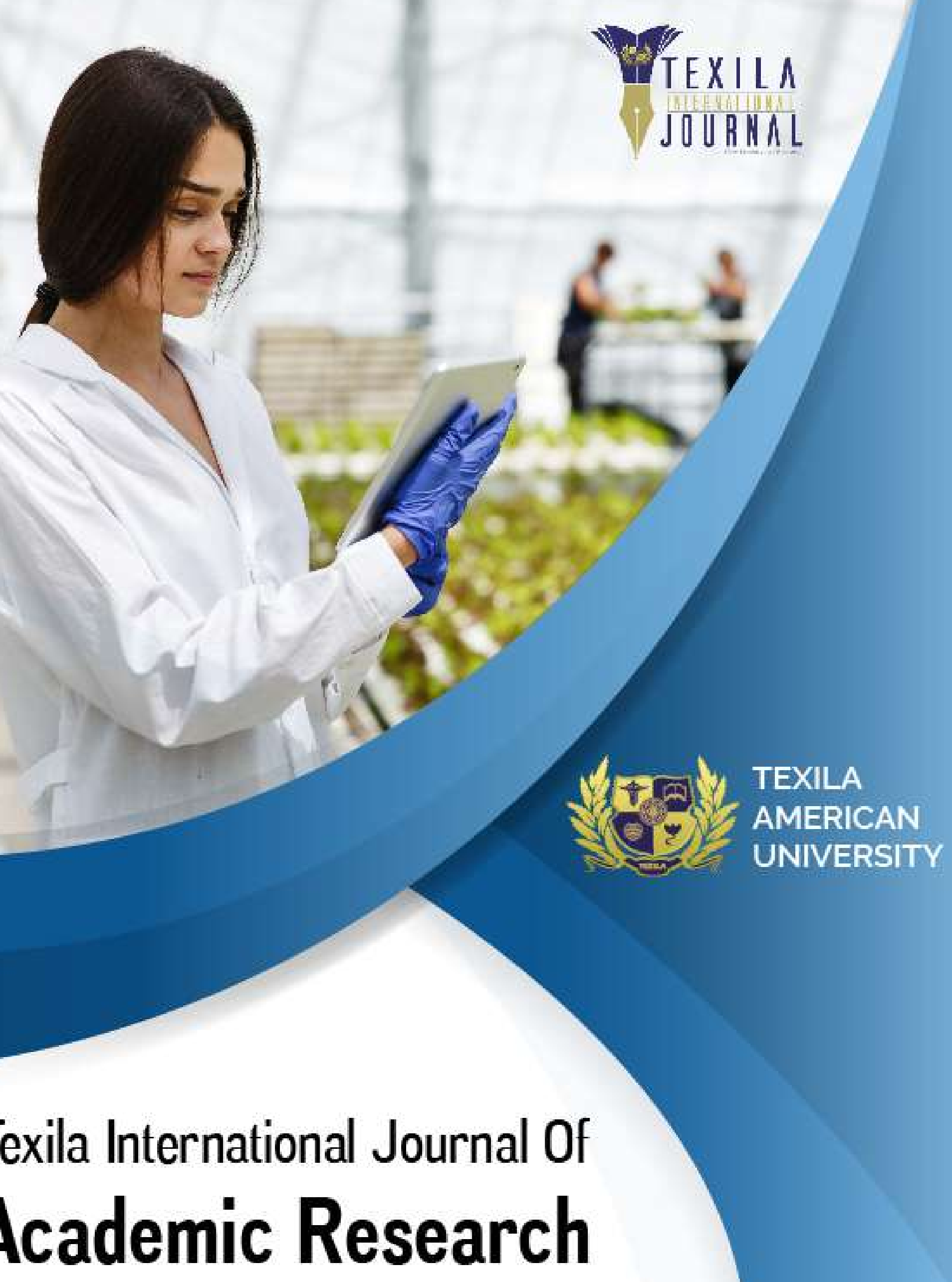

Texila International Journal of Academic Research

VOLUME 6 | ISSUE 1 | ISSN : 2520-310X 


\section{EDITORIAL POLICY}

Papers must be submitted with the understanding that they have not been published elsewhere (except in the form of an abstract or as part of a published lecture, review, or thesis) and are not currently under consideration by another journal published or any other publisher. The submitting (Corresponding) author is responsible for ensuring that the article's publication has been approved by all the other coauthors. It is also the authors' responsibility to ensure that the articles coming from a particular institution are submitted with the approval of the necessary institution. Only an acknowledgment from the editorial office officially establishes the date of receipt. It is a condition for submission of a paper that the authors permit editing of the paper for readability. All enquiries concerning the publication of accepted papers should be addressed to ejournal.assist @tau.edu.gy.

\section{PEER REVIEWERS}

Dr. Rakesh Ranjan, Educational Management and Administration, MAEERs Vishwashanti Gurukul School, Solapur.

Dr. Rakesh Kumar, Manger Examinations, Texila Educational and Management Services. 


\section{ABOUT PLAGIARISM}

Plagiarism is the use or close imitation of the language and ideas of another author and representation of them as one's own original work. Duplicate publication, sometimes called self-plagiarism, occurs when an author reuses substantial parts of his or her own published work without providing the appropriate references. This can range from getting an identical paper published in multiple journals, where authors add small amounts of new data to a previous paper.

Plagiarism can be said to have clearly occurred when large chunks of text have been cut and pasted. Such manuscripts would not be considered for publication in TIJBMS Journal. But minor plagiarism without dishonest intent is relatively frequent, for example when an author reuses parts of an introduction from an earlier paper. The editors will judge any case of which they become aware (either by their own knowledge of and reading about the literature, or when alerted by referees) on its own merits.

The paper containing the plagiarism will be obviously returned back to the author's for review, but we earnestly request the authors to avoid submitting plagiarized 


\section{DISCLAIMER}

Texila International Journal of Academic Research (TIJAR) make every effort to ensure the accuracy of all the information (the "Content") contained in its publications. However, the TIJAR and its agents make no representations or warranties whatsoever as to the accuracy, completeness or suitability for any purpose of the Content and disclaim all such representations and warranties whether express or implied to the maximum extent permitted by law. Any views expressed in this publication are the views of the authors and are not necessarily the views of the Editor's or Texila International Journal of Academic Research. 


\section{TABLE OF CONTENT}

1 A Study on Workers' Satisfaction towards Job with Respect to Mobile Telephone

Network Cameroon (MTNC)

Kenyuyfoon Joan Mary Wirnkar

2 The Impact of Gender Based Violence on Child Development in Livingstone

District of Zambia

Chanda Florence

3 At Crossroads: Reflections on the Efficacy of the Southern African Development

Community (SADC) in Conflict Resolution in Zimbabwe and the DRC

Feddious Mutenheri

4 The Impact of Technology in Public Sectors Workers' Performances in Nigeria:

Case of Federal Ministry MDAs and Agencies

Fred-Osogu Obioma

5 Strategic Management and Corporate Planning, Tools to Achieving Organizational

Products Continuous Efficiency: The Case of Multi- National Company's Products

in Nigeria

Osogu Fred Obioma

6 The Challenges in Analyzing Project Management Principles in Service Delivery in the Issuance of Driver's License (A Case Study the Driver's and Vehicle Licensing Authority (DVLA) of Ghana.)

\section{Daniel Quansah}

7 Organizational Economics, the Firm, \& the Entrepreneur: A Motivation for the Emergence of the Entrepreneur as Coordinator of Organizational Resources for Firm Success

Chilumba K. Bwalya

8 The Extent of the Zambian Government's Support in Eradicating the Challenges Faced by Early Childhood Teachers in Zambia 


\title{
A Study on Workers' Satisfaction towards Job with Respect to Mobile Telephone Network Cameroon (MTNC)
}

\author{
Article by Kenyuyfoon Joan Mary Wirnkar \\ Texila American University Georgetown, Guyana, South America \\ E-mail:wirnkarjoan@yahoo.com
}

\begin{abstract}
Job satisfaction has something to do with how committed an employee is towards its company which is a very important factor. Job satisfaction is a very important subject in the professional world and numerous researches have been done and still been done on this topic to better answer the hypothesis surrounding job satisfaction

The researcher has chosen to study this issue because she happens to have been an employee of company under case study for a cumulative period of two (2) years where in she at some point experienced low job satisfaction about the job and other colleagues shared the same feeling. The researcher is interested in this topic so that, from the results obtained, the management will be aware of the many reasons why employees in their company have low, little or no job satisfaction of which they tend to neglect.
\end{abstract}

\section{Research objectives}

1. To measure the workers' job satisfaction level.

2. To identify the factors influencing job satisfaction.

3. To know how the workers' satisfaction towards job, influence degree of work fulfillment.

4. To identify the attitude of employees towards job.

5. To suggest the ways to improve job satisfaction.

\section{Introduction}

The concept of job satisfaction, viewed through different lenses by various scholars, is defined differently. Greenberg and Baron (2008), for instance, viewed job satisfaction as a feeling that can produce a positive or negative effect toward one's roles and responsibilities at work and added that it is important to understand the concept of job satisfaction as there is no single way to satisfy all workers in the workplace. Greenberg and Baron (2008) saw it as a positive feeling toward a person's job. This concept, according to George and Jones (2005), is the combination of feelings and beliefs, which include the mental, emotional, and physical domains. Job satisfaction can also be defined as a worker's emotional response to different job-related factors resulting in finding pleasure, comfort, confidence, rewards, personal growth and various positive opportunities, including upward mobility, recognition and appraisal done on a merit pattern with monetary value as compensation (Robbins \& Judge, 2007; George \& Jones, 2005). Arnett, Laverie and McLane's (2002) definition is summarized by saying that job satisfaction is reflected as an employee's general affective assessment of himself/herself in the context of his or her job.

Abbas (2011) reported that financial factors, working conditions, supervision and advancement opportunities are associated with the overall satisfaction of the banking professionals. Archana Singh et al. (2011) reported that factors namely, pay, job interest, leadership, career growth, working environment, job responsibility etc. serves as stimulators for employee satisfaction in technology sector. Deshwal (2011) also found that the factors named as working conditions, organizational policies, independence, promotion opportunities, work variety, creativity, compensation, work itself, colleagues' cooperation, responsibility, social status of job, job security, achievement and students' interaction were associated with job satisfaction. 
DOI: 10.21522/TIJAR.2014.06.01.Art001

ISSN: $2520-3088$

From all the definitions of job satisfaction that we have observed, we can see that money is just one of the many reasons why employees will be satisfied with their jobs. This is the reason why this study is been under study to see the case with MTNC, what satisfies employees more and by extension what about their job keeps them unsatisfied.

\section{Literature review}

According to the research work of Koge Henry M.M, (2015) on job satisfaction and motivation of secondary school teachers, a case study of the South West Region of Cameroon. Research on job satisfaction began with the Haw Thorne studies, conducted from 1924_1932, focusing on the psychological and social factors in the work place. Hoppack (1953) on his part did an intensive study on job satisfaction. From the interview he carried out, he identified that job satisfaction was influenced by factors found in the work environment such as supervision and family expectation.

Kwathawala et al (1990), in the results of his survey done for his study found out that, the prime factor of motivation and job satisfaction for employees of the automobile industry was salary. The result showed that compensation was ranked as the number one job element for job satisfaction.

Ana and Patricia (2014) suggest that job characteristics have a huge influence on workers' level of satisfaction and as a consequence, on the quality of work that they perform.

Monia L. and Nico Martins (2010) in their study on employee satisfaction in a South African information and Technology organization found out that, there is a strong positive correlation between organizational climate and job satisfaction. It equally indicated a positive relation between organizational climate scores and job satisfaction scores thus regardless of how the dimensions are perceived; organizational climate has an influence on job satisfaction.

Emira Kozarevic (2014), the analysis of the survey in her article "Job Satisfaction of Banking Sector". Employees in Bosnia reveal that, job satisfaction amongst the bankers is determined by a wide spectrum of factors such as demographic characteristics, management and supervision, monetary compensation, non-monetary recognition, work environment, job responsibility and type of tasks, social atmosphere at work and general satisfaction with life.

Bochen Pan (2015) explains that, perceived organizational support, psychological capital and higher monthly income were positively associated with job satisfaction among the university teachers in the North Eastern Region of China. Age to him was also linked to the level of job satisfaction. Results of the study indicate that improving the perceived organizational support may increase the level of job satisfaction for university teachers.

Eyasu and Antehun (2017) conducted a study on job satisfaction and determinant factors among midwives working at health facilities in Addis Ababa. Results showed that, midwives were least satisfied from salary, extrinsic reward and professional opportunity subscales while they were most satisfied from coworker relation and the standard of care they provided to clients.

Adeniji (2011) in his study on Organizational Climate and Job Satisfaction among Academic Staff in some Selected Private Universities in Southwest Nigeria. The study was based on the responses received from 293 respondents of five private Universities in the South-West Zone of Nigeria. The results showed a positive relationship between organizational climate and job satisfaction. Herzberg's Two Factor theory was used as a framework for this study.

Dev (2012) in his study on Public and Private Sector Banks found that clients of private sector banks are more satisfied than those of public sector banks in most of the dimensions except Interest rates and other charges and accessibility whereas the clients of public sector banks are more satisfied than clients of private sector. One area where both types of banks are lacking the most is customer orientation. Performance norms have also suffered in all types of banks. It was also observed that banks in India, especially the public sector banks need to equip themselves with the latest technology.

Gurusamy and Mahendran (2013), in their study found that salary occupy the first rank for determining job satisfaction compared with other major determinants. The study was conducted on 300 respondents and was limited to the automobile industries of India. 
Rashid Saeed et al.., (2014), in his study found promotion, pay, fairness and working condition to be the key factors that contribute to employee job satisfaction. The study was conducted on 200 telecom sector employees of Pakistan. It was concluded that money and compensation play an important role in the job satisfaction of the telecom employees of Pakistan.

Resheske (2001) examined job satisfaction among full time faculty of the College of Human Development at Wiscosin University. Thirty-six full time members were included in the study. The results indicated that overall the faculty of the College of Human Development at UW-Stout was satisfied with their current employment and that group cohesion does play a role in overall job satisfaction. The study also determined that job autonomy, working with the students and fellow colleagues and supervisors were the top three best reasons for working here. It was also concluded that pay, having more time and assistance with meeting deadlines and having equal workloads between colleagues were three top priorities for improving the work environment.

Vagh (2010) highlighted that most of the employees of Municipal Corporation of Saurashtra Region were not satisfied. Employees of the Municipal Corporations have many questions and there is a strong need to give the attention on solution of employees' questions as and when it arises.

Singh and Myers (2013), highlights on employee's job satisfaction and its impact on their performance. Employees' attitude reflects the moral of the company. Happy employees play an important role in the areas of customer's service and sales as they are the one to interact with the customer on a daily basis. Work environment is the key factor in job satisfaction. Good work environment and good working conditions leads to job satisfaction at the same time helps in increasing employee work performance, profitability, customer satisfaction as well as retention.

Aristovnik (2014) discusses influence of organizational and environmental factors on employee job satisfaction. The police employees rated salary and security as the least motivator and support from the management as high. Police employees rate trust and belongingness as the key factor to job satisfaction.

\section{People}

Mobile Telephone Network Cameroon has about Nine Hundred and Thirty-Four employees spread across Cameroon.

\section{Study design}

For this research work, the researcher I adopted the probability sample method which by extension is the simple random sampling method. The rationale for using this sampling method was due to the fact that, the population under study is known to the researcher and so every one has equal chances of been selected and this is so because the researcher utilized randomization. This sampling method is so effective because there is an absence of systematic and sampling bias. Probability sample method depicts a full representation of the whole population Welman and Kruger (2001). Taking in to cognizance that the probability sample was used, the validity of the study is guaranteed. A quantitative research method was used to carry out research on job satisfaction. The instrument used to gather data was a questionnaire which was self-administered by extension; the primary data source was used by the researcher because fresh information was obtained for the purpose of this study. In as much as primary data source is quite expensive and time consuming compared to secondary data source, notwithstanding, primary data collection may be the only suitable method for some types of research. The most common techniques primary data collection is by self-administered surveys like questionnaires which were used for this study. The limitations of using a questionnaire as means of collecting data has been outline by Bell (1999)

- The response rate for questionnaires often has a low response rate.

- The questionnaire does not give the researcher to follow up ideas and clarify issues.

\section{Population}

The populations targeted in this study included middle level employee and high-level employee, both permanent and contract employees making a total of 150 employees across all departments of the company. 
DOI: 10.21522/TIJAR.2014.06.01.Art001

ISSN: $2520-3088$

\section{Sample}

The researcher encouraged and convinced the employees to partake in the study. Thus, eighty questionnaires were administered (80) of which response was received from eighty (80). employees producing a $100 \%$ response rate. What triggered this response rate is the fact that the researcher was ones an employee of the company therefore; there was already some degree of trust between respondents and researcher.

The sample consisted on permanent and contract employees, males and females, different job levels as well as salary levels.

\section{Sources of data collection and tools for analysis}

\section{Primary data}

The UCLA Institute on Primary Resources states that, primary sources of data provide the researcher with firsthand information. They include statistical data, historical and legal documents. Interviews, surveys, communication via email are also sources of primary data. In our study, primary data was used by means of a survey; a self-administered questionnaire. The researcher chose to use primary source of data because it presents information in its original form and allows the researcher to perform original analysis then formulate your own theory or opinion.

\section{Secondary data}

In social sciences, secondary source or data is usually a scholar book, journal article created by someone who did not directly participate in the conditions under investigation. Secondary data provide an interpretation, analysis derived from primary source materials. In this study, the researcher implored secondary data while forming the literature review in this study. The secondary data source was extracted from journal articles so as to form the basis of the assertion in the research. Secondary data source is easy to go about because it saves time that would have otherwise been used for collecting data. Using secondary source data in a research study has some setbacks, some of which are;

- Information gotten from secondary data is sometimes outdated.

- Most often, the study problems are not included in secondary data sources. This is because the data was originally created for a different purpose and therefore may not be optimal for the study purpose.

\section{Research hypothesis}

Hyp 1: there is no relationship between age and how satisfied are you at present with your physical working conditions (heat, noise, light, cleanliness, space, ventilation etc)

Hyp 2: there is no relationship between marital status and I would consider leaving the company for another company that was offering slightly higher salary

Hyp 3: there is no relationship between age and on the job, do you feel any pressure for increasing the work you do above what you think is reasonable

Hyp 4: there is no relationship between marital status and how satisfied are you with your involvement in decisions that affect your work

Hyp 5: there is no relationship between income and in comparison, with people in similar jobs in other companies, I feel my pay is

Hyp 6: there is no relationship between income and how satisfied are you with the extent to which your job leaves sufficient time for your personal life or family life

Hyp 7: there is no relationship between age and how satisfied are you with the training you receive for your current job

Hyp 8: there is no relationship between gender and I would recommend the company to my friends as a place to work

Hyp 9: there is no relationship between income and my job makes good use of my skills 
Hyp 10: there is no relationship between marital status and how satisfied are you with the recognition you get when you do a good job.

\section{Tools for analysis}

The tools for the analysis refer to the techniques used to analyze the data. In this study, the chi square and Analysis of Variance (ANOVA) were used as tools to analyze data. The chi square test is used to determine whether there is a significant difference between the expected frequencies and the observed frequencies. On the other hand, ANOVA provided statistical estimates of the variability in test scores associates with systematic differences in the ratings assigned and differences in the ratings obtained Murphy and David (2001). This statistical method is used to establish whether statistically significant differences exist in job satisfaction based on biographical variables.

\section{Statistical analysis}

All returned questionnaires will be analyzed in a computer using Statistical Package for Social Sciences (SPSS). Confidence interval would be used and P-value of 0.05 considered as statistically significant. To analyze the employee satisfaction, respondents would be categorized into the above mentioned two groups' relationship or no relationship of questions posed and variables. The explanatory variables selected were based on the study hypotheses. We assessed vicariate associations between all variables and employee satisfaction. Differences between the associated explanatory variables would be analyzed subsequently by comparing means using t-tests and chi-square tests.

\section{Analysis and Interpretation}

\section{Percentage analysis}

\section{Marital status of respondents}

\begin{tabular}{|l|l|l|l|l|l|}
\hline \multicolumn{2}{|l|}{ Marital } & Frequency & Percent & Valid Percent & $\begin{array}{l}\text { Cumulative } \\
\text { Percent }\end{array}$ \\
\hline \multirow{4}{*}{ Valid } & married & 100 & 79.4 & 79.4 & 79.4 \\
\cline { 2 - 7 } & Unmarried & 26 & 20.6 & 20.6 & 100.0 \\
\cline { 2 - 7 } & Total & 126 & 100.0 & 100.0 & \\
\hline
\end{tabular}

\section{Inference}

The above table shows that, majority 79.4 percent of the respondents are married and 20.6 percent of the respondents are unmarried.

\section{Marital status of respondents}

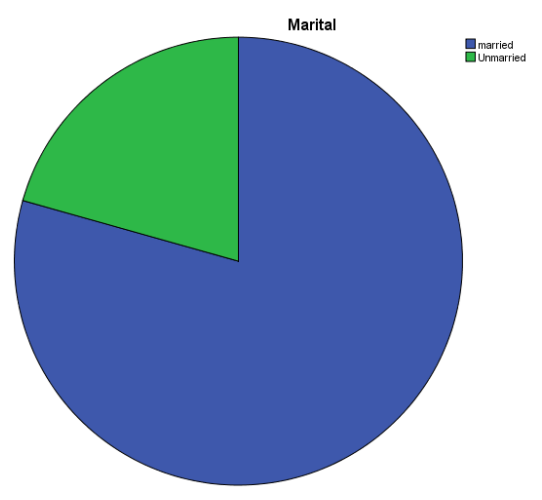


DOI: 10.21522/TIJAR.2014.06.01.Art001

ISSN: $2520-3088$

Table 4.1.2. Income of respondents

\begin{tabular}{|c|c|c|c|c|c|}
\hline \multicolumn{6}{|c|}{ Income } \\
\hline & & Frequency & Percent & Valid Percent & $\begin{array}{l}\text { Cumulative } \\
\text { Percent }\end{array}$ \\
\hline \multirow{4}{*}{ Valid } & less than $500 \$$ & 37 & 29.4 & 29.4 & 29.4 \\
\hline & $501 \$-1000 \$$ & 32 & 25.4 & 25.4 & 54.8 \\
\hline & $1001 \$-1500 \$$ & 57 & 45.2 & 45.2 & 100.0 \\
\hline & Total & 126 & 100.0 & 100.0 & \\
\hline
\end{tabular}

\section{Inference}

The above table shows that, 45.2 percent of respondents earn $1001 \$-1500 \$ .29 .4$ percent of respondents earn less than $500 \$$ and 25.4 percent of respondents earn $501 \$-1000 \$$.

\section{Income of respondents}

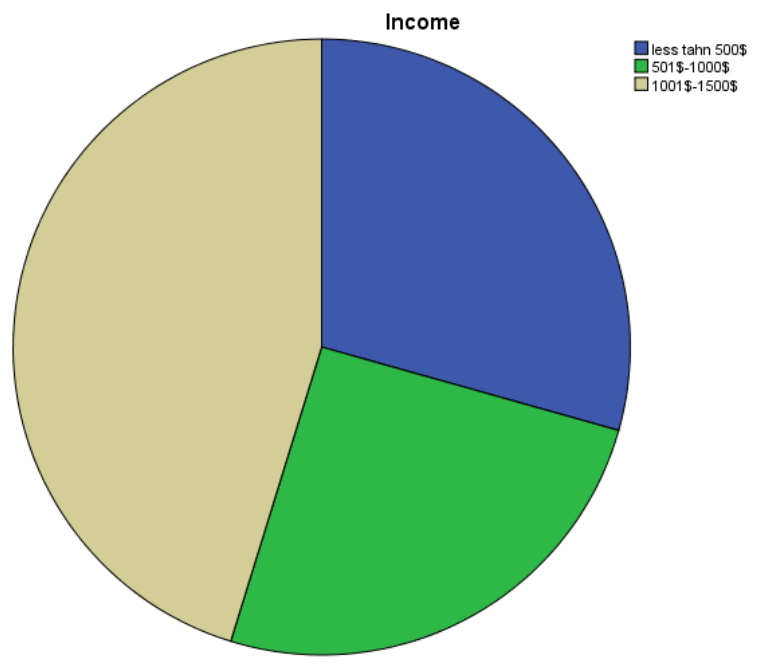

Gender of respondents

\begin{tabular}{|l|l|l|l|l|l|}
\hline \multicolumn{2}{|l}{ Gender } & Frequency & Percent & Valid Percent & Cumulative Percent \\
\hline \multirow{4}{*}{ Valid } & male & 81 & 64.3 & 64.3 & $\mathbf{6 4 . 3}$ \\
\cline { 2 - 6 } & female & 45 & 35.7 & 35.7 & $\mathbf{1 0 0 . 0}$ \\
\cline { 2 - 6 } & Total & $\mathbf{1 2 6}$ & $\mathbf{1 0 0 . 0}$ & $\mathbf{1 0 0 . 0}$ & \\
\hline
\end{tabular}

\section{Inference}

The table above shows that 64.3 percent are male respondents and 35.7 percent are female respondents. 


\section{Gender of respondents}

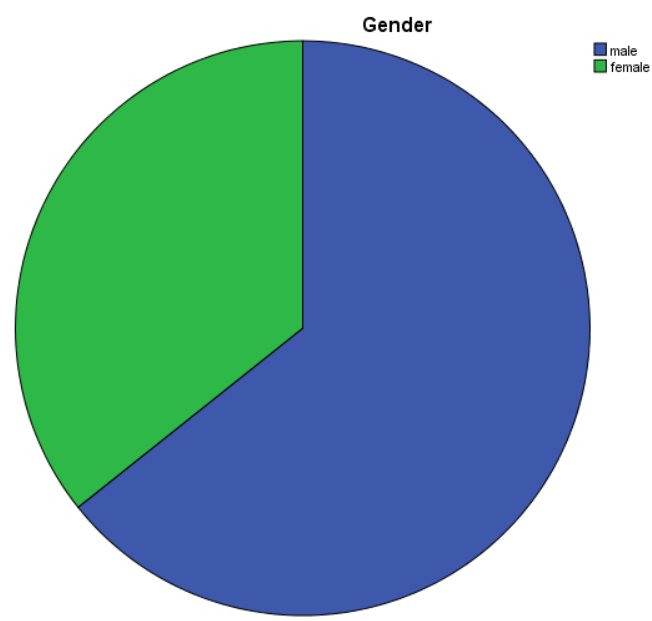

Age group of respondents

\begin{tabular}{|l|l|l|l|l|l|}
\hline \multicolumn{2}{|l|}{ Age } & \multicolumn{2}{l|}{} \\
\hline \multicolumn{2}{|l|}{} & & & & \\
\hline \multirow{5}{*}{ Valid } & $\mathbf{2 6 - 3 0}$ & 69 & 54.8 & 54.8 & $\mathbf{5 4 . 8}$ \\
\cline { 2 - 6 } & $\mathbf{3 1 - 3 5}$ & 31 & 24.6 & 24.6 & $\mathbf{7 9 . 4}$ \\
\hline & $\mathbf{3 6 - 4 0}$ & 15 & 11.9 & 11.9 & $\mathbf{9 1 . 3}$ \\
& $\mathbf{4 1 - 4 5}$ & 11 & 8.7 & 8.7 & $\mathbf{1 0 0 . 0}$ \\
\cline { 2 - 6 } & Total & $\mathbf{1 2 6}$ & $\mathbf{1 0 0 . 0}$ & $\mathbf{1 0 0 . 0}$ & \\
\hline
\end{tabular}

\section{Inference}

The Table above shows that 54.8 percent of the respondents are between 26-30 age groups. 24.6 percent of the respondents are between age group 31-35. 11.9 percent of the respondents are of the age group 36-40. The other 8.7 percent respondents are of the age group 41-45.

\section{Hypothesis (1)}

Null Hypothesis (Ho): there is no relationship between age and how satisfied are you at present with your Physical working conditions (heat, noise, light, cleanliness, space, ventilation etc)

Alternate Hypothesis (H1): there is a relationship between age and how satisfied are you at present with your Physical working conditions (heat, noise, light, cleanliness, space, ventilation etc)

\section{Interpretation of results}

Since the P-value (0.000) is less than the significance level (0.05), we reject the null hypothesis and accept alternate hypothesis. Thus, we conclude that there is a relationship between age and how satisfied are you at present with your physical working conditions (heat, noise, light, cleanliness, space, ventilation etc).

\section{Hypothesis (2)}

Null Hypothesis (Ho): there is no relationship between marital status and I would consider leaving the company for another company that was offering slightly higher salary. 
DOI: 10.21522/TIJAR.2014.06.01.Art001

ISSN: $2520-3088$

Alternate Hypothesis (H1): there is a relationship between marital status and I would consider leaving the company for another company that was offering slightly higher salary.

\section{Test statistics}

\begin{tabular}{|l|l|l|}
\hline & Marital & Leaving the company \\
\hline Chi-Square & $43.460^{\mathrm{a}}$ & $24.333^{\mathrm{b}}$ \\
\hline Df & 1 & 2 \\
\hline Asymp. Sig. & .000 & .000 \\
\hline
\end{tabular}

a. 0 cells $(0.0 \%)$ have expected frequencies less than 5 . The minimum expected cell frequency is 63.0.

b. b. 0 cells $(0.0 \%)$ have expected frequencies less than 5 . The minimum expected cell frequency is 42.0.

\section{Interpretation of results}

since the p-value (0.000) is less than the significance level (0.05), we reject the null hypothesis and accept the alternate hypothesis. Thus, we conclude that there is a relationship between marital status and I would consider leaving the company for another company that was offering slightly higher salary.

\section{Hypothesis (3)}

Null Hypothesis (Ho): There is no relationship between age and on the job, do you feel any pressure for increasing the work you do above what you think is reasonable.

Alternate Hypothesis (H1): there is a relation between age and on the job, do you feel any pressure for increasing the work you do above what you think is reasonable.

\section{Test Statistics}

\begin{tabular}{|l|l|l|}
\hline & Age & On the job \\
\hline $\begin{array}{l}\text { Chi- } \\
\text { Square }\end{array}$ & $66.635^{\mathrm{a}}$ & $2.571^{\mathrm{b}}$ \\
\hline Df & 3 & 1 \\
\hline $\begin{array}{l}\text { Asymp. } \\
\text { Sig. }\end{array}$ & 000 & .109 \\
\hline
\end{tabular}

a. 0 cells $(0.0 \%)$ have expected frequencies less than 5 . The minimum expected cell frequency is 31.5.

b. b. 0 cells $(0.0 \%)$ have expected frequencies less than 5 . The minimum expected cell frequency is 63.0.

\section{Interpretation of results}

Since the P-value (0.000) is less than the significance level (0.05), we reject the null hypothesis and accept the alternate hypothesis. Thus, we conclude that there is relationship between age and on the job, do you feel any pressure for increasing the work you do above what you think is reasonable.

\section{Hypothesis (4)}

Null Hypothesis (Ho): there is no significant difference between marital status and how satisfied are you with your involvement in decisions that affect your work.

Alternate Hypothesis (H1): there is a significant difference between marital status and how satisfied are you with your involvement in decisions that affect your work. 


\begin{tabular}{|l|l|l|l|l|l|}
\hline ANOVA \\
\hline Marital & Sum of Squares & df & Mean Square & F & Sig. \\
\hline & 1.463 & 2 & .732 & 4.694 & .011 \\
\hline Between Groups & 19.172 & 123 & .156 & & \\
\hline Within Groups & 20.635 & 125 & & & \\
\hline Total & & & & \\
\hline
\end{tabular}

\section{Interpretation of results}

The calculated value $(0.011)$ is less than the significance value $(0.05)$. Hence, we reject the null hypothesis and accept the alternate hypothesis. Thus, there is a significant difference between marital status and how satisfied are you with your involvement in decisions that affect your work.

\section{Hypothesis (5)}

Null Hypothesis (Ho): There is no difference between income and in comparison, with people in similar in jobs in other companies I feel my pay is.

Alternate Hypothesis: There is a difference between income and in comparison, with people in similar in jobs in other companies I feel my pay is.

\begin{tabular}{|l|l|l|l|l|l|}
\hline ANOVA \\
\hline Income & Sum of Squares & df & Mean Square & F & Sig. \\
\hline & 34.549 & 2 & 17.274 & 37.755 & .000 \\
\hline Between Groups & 56.277 & 123 & .458 & & \\
\hline Within Groups & 90.825 & 125 & & & \\
\hline Total &
\end{tabular}

\section{Interpretation of results}

The calculated value (0.000) is less than the significance value $(0.05)$. We therefore reject the null hypothesis and accept the alternate hypothesis. Thus, there is significant difference between income and in comparison, with people in similar in jobs in other companies I feel my pay is.

\section{Hypothesis (6)}

Null Hypothesis (Ho): there is no significant difference between income and how satisfied are you with the extent to which your job leaves you sufficient time for your personal life or family life.

Alternate Hypothesis (H1): there is a significant difference between income and how satisfied are you with the extent to which your job leaves you sufficient time for your personal life or family life.

\begin{tabular}{|l|l|l|l|l|l|}
\hline ANOVA \\
\hline Income & Sum of Squares & df & Mean Square & F & Sig. \\
\hline & 33.556 & 3 & 11.185 & 23.827 & .000 \\
\hline Between Groups & 57.270 & 122 & .469 & & \\
\hline Within Groups & 90.825 & 125 & & & \\
\hline Total & & & & \\
\hline
\end{tabular}

\section{Interpretation of results}

Since the P-value (0.000) is less than the significance level (0.05), we accept the null hypothesis and reject the alternate hypothesis. We conclude that there is a significant difference between income and how satisfied are you with the extent to which your job leaves you sufficient time for your personal life or family life. 
DOI: 10.21522/TIJAR.2014.06.01.Art001

ISSN: $2520-3088$

\section{Hypothesis (7)}

Null Hypothesis (Ho): there is no relationship between age and how satisfied are you with the training you receive for your current job.

Alternate Hypothesis (H1): there is a relationship between age and how satisfied are you with the training you receive for your current job.

\begin{tabular}{|l|ll|}
\hline \multicolumn{2}{|l|}{ Test Statistics } & \multicolumn{2}{l|}{} \\
\hline & Age & Training \\
\hline Chi-Square & $66.635^{\mathrm{a}}$ & $34.333^{\mathrm{b}}$ \\
\hline Df & 3 & 2 \\
\hline Asymp. Sig. & .000 & .000 \\
\hline
\end{tabular}

a. 0 cells $(0.0 \%)$ have expected frequencies less than 5 . The minimum expected cell frequency is 31.5 .

b. b. 0 cells $(0.0 \%)$ have expected frequencies less than 5 . The minimum expected cell frequency is 42.0 .

\section{Interpretation of results}

Since the P-value (0.000) is less than the significance level $(0.05)$, we reject the null hypothesis and accept the alternate hypothesis. Thus, we conclude that there is a relationship between age and how satisfied are you with the training you receive for your current job.

\section{Hypothesis (8)}

Null Hypothesis (Ho): There is no relationship between gender and I would recommend the company to my friend as a place to work.

Alternate Hypothesis (H1): There is a relationship between gender and I would recommend the company to my friend as a place to work.

\section{Test statistics}

\begin{tabular}{|l|l|l|}
\hline & Gender & Recommend the company \\
\hline Chi-Square & $10.286^{\mathrm{a}}$ & $104.143^{\mathrm{b}}$ \\
\hline $\mathrm{Df}$ & 1 & 2 \\
\hline $\mathrm{Ce}$ & .001 & .000 \\
\hline
\end{tabular}

a. 0 cells $(0.0 \%)$ have expected frequencies less than 5 . The minimum expected cell frequency is

b. 0 cells $(0.0 \%)$ have expected frequencies less than 5 . The minimum expected cell frequency is 42.0.63.0.

\section{Interpretation of results}

Since the P-value (0.000) is less than the significance level (0.05), we reject the null hypothesis and accept the alternate hypothesis. Thus, we conclude that, there is a relationship between gender and I would recommend the company to my friend as a place to work.

\section{Hypothesis (9)}

Null Hypothesis (Ho): There is no relationship between income and my job makes good use of my skills.

Alternate Hypothesis (H1): There is a relationship between income and my job makes good use of my skills. 
Test statistics

\begin{tabular}{|l|l|l|}
\hline & Income & Skills and ability \\
\hline Chi-Square & $8.333^{\mathrm{a}}$ & $2.571^{\mathrm{b}}$ \\
\hline Df & 2 & 1 \\
\hline $\begin{array}{l}\text { Asymp. } \\
\text { Sig. }\end{array}$ & .016 & .109 \\
\hline
\end{tabular}

a. 0 cells $(0.0 \%)$ have expected frequencies less than 5 . The minimum expected cell frequency is 42.0.

b. 0 cells $(0.0 \%)$ have expected frequencies less than 5 . The minimum expected cell frequency is 63.0.

\section{Interpretation of results}

Since the P-value (0.109) is greater than the significance level (0.05), we accept the null hypothesis and reject the alternate hypothesis. Thus, we conclude that there is no relationship between income and my job makes good use of my skills.

\section{Hypothesis (10)}

Null Hypothesis (Ho): There is no significant difference between marital status and how satisfied are you with the recognition you get when you do a good job.

Alternate Hypothesis (H1): There is a significant difference between marital status and how satisfied are you with the recognition you get when you do a good job.

\begin{tabular}{|l|l|l|l|l|l|}
\hline ANOVA \\
\hline Marital & Sum of Squares & df & Mean Square & F & Sig. \\
\hline & 1.779 & 1 & 2.779 & 19.303 & .000 \\
\hline Between Groups & 17.855 & 124 & .144 & & \\
\hline Within Groups & 20.635 & 125 & & & \\
\hline Total & 2061 & & & \\
\hline
\end{tabular}

\section{Interpretation of results}

Since the P-value (0.000) is less than the significance level (0.05), we reject the null hypothesis and accept the alternate hypothesis. Thus, we conclude that there is a significant difference between marital status and how satisfied are you with the recognition you get when you do a good job.

\section{Limitations}

The results that will emanate from this research work will be limited to the research method that was used and the data set. The results also are limited to a particular case study taken from a telecommunication company in Douala Cameroon. This study did not rely on self-report on all measured variables, which is good for reducing the likelihood for common bias. Also, being an academic study, the time at hand to conduct the research and limited study period left will not be adequate, considering the area of the research.

\section{Findings}

\section{Findings based on testing hypothesis}

1. From the analysis, it is found that there is a significant difference between marital status and how satisfied are you with your involvement in decisions that affect your work.

2. It is observed that there is a relationship between age and on the job, do you feel any pressure for increasing the work you do above what you think is reasonable. 
DOI: 10.21522/TIJAR.2014.06.01.Art001

ISSN: $2520-3088$

3. Analysis shows that there is no significant difference between marital status and I would consider leaving my company for another company that was offering slightly higher salary.

4. It is found that found that there is a significant difference between income and how satisfied are you with the extent to which your job leaves you sufficient time for your personal life or family life.

5. It is observed that there is a relationship between age and how satisfied are you at present with your physical working conditions (heat, noise, light, cleanliness, space, ventilation).

6. Analysis of hypothesis shows that there is a significant difference between income and in comparison, with people in similar jobs in other companies; I feel my pay is either low or high.

7. It is observed from hypothesis analysis that there is a relationship between age and how satisfied one gets with the training received for your current job.

\section{Conclusion}

Every organization is comprised of people. Acquiring their services, developing their skills, motivating them to high levels of performance, and ensuring that they maintain their commitment to the organization is essential to achieving organizational objectives. Human Resource Management is that part of management which is concerned with people at work and their relationships within the enterprise. The primary objective of HRM is to ensure the availability of a competent and willing workforce to an organization. The topic for this research study has been identified in this context!

The issue of employee satisfaction has been found to have huge economic impact on organizations. To analyze the factors that affect employee satisfaction in MTNC, the researcher carried out a research survey which was aimed at identifying the factors that cause employee dissatisfaction and suggesting remedial measures to address this.

The study came up with measures that the HRM of MTNC has to adopt in order to maintain their employees satisfied. One of those very important measures was visibility on career plan for each employee and introducing a highly competitive salary package.

In order to have a stress-free work environment, companies must reduce the long working hours and should also introduce flexible work timings which will permit employees have sufficient time for their personal lives, thereby leading to employee satisfaction.

\section{Reference}

[1]. Aarti Sharma, (2013). Job satisfaction among bank employees. International Journal of Scientific and Technology Research, Vol.2, Issue 8.

[2]. Abbas. S.M Shariq (2011). Banking professionals and attitudinal dimensions of job satisfaction: A descriptive study. International Journal of Research in Commerce, I.T, and Management. Vol. 1, Issue 6.

[3]. Annierah Maulana Usop (2013) Work performance and job satisfaction among teachers.

[4]. International Journal of Humanities and Social Science. Vol.3, No.5, pp. 245-252.

[5]. www.google.com (Retrieved on 15th June, 2018).

[6]. www.wikipedia.com Retrieved on 15th June, 2018).

[7]. www.dorj.org.

[8]. www.jurn.org. 


\title{
The Impact of Gender Based Violence on Child Development in Livingstone District of Zambia
}

\author{
Article by Chanda Florence \\ Texila American University \\ E-mail: florencemulanshoka@gmail.com
}

\begin{abstract}
Gender based violence exposure happens in different social contexts of children's lives including families and communities. This often occurs in different form of violence exposures. Children are likely to be exposed to violence at a tender age and when they grow a bit old. In Zambia, Children in highdensity populated areas are disadvantaged and are more exposed to violence. For young children, it has been identified that where violence affects the one who is taking care of the child it means the child will be affected too. As the child grows with this violence exposure, the child's social, mental, emotional and academic performance out comes may be affected.

Children's exposure to violence has received less attention than of older children, it is an especially important developmental period when children are developing social and cognitive skills and preparing for transition to formal schooling. Gender based violence can be the evil in terms of child development.

Violence exposure in the lives of children can include different ways of which children experience. This can be within the family and the community and this affects the physical, emotional and mental development in a child.

In Zambia, Gender-based violence' is a form violence that has come on the scene and very common. This has brought problems in most people's lives and causing children to suffer also and in some cases, children ending up to be living on the streets resulting in street children and poor performance in school, in some cases children even drop out of school. Gender based violence is mostly inflicted by men on women. Women are the most victims of gender-based violence and this leads children to be exposed to different forms of violence. This is so because most of the time women are always with the children.

When young children are exposed to violence in the community and in their families, their behavior out comes is questionable. According to the ministerial, report by the Minister of Gender 2015 states, "Children who witness or are the victims of violence may learn to believe that violence is a reasonable way to resolve conflict between people. Boys who learn that women are not to be valued or respected and who see violence directed against women are more likely to abuse women when they grow up.
\end{abstract}

Keywords: Gender, Gender based violence, Child development, Impact, Witnessing, Hearing.

\section{Introduction}

This article reviews 'The impact of Gender based violence on Child development in Livingstone District of Zambia". Exposure to violence at a tender age increases the risk for polluted nation. Children who experience this violence grow up to hate and will have no feelings for others. This increases the high rate of school dropouts and hard-core criminals.

Women have the ability to promote a positive, constructive environment, but in order to do so they need social support from all circles. Women who are in a psychologically or physically abuse relationship with an intimate partner, possibly because of reasons explained through the Intergenerational Transmission Theory, are at least twice as likely to exhibit abuse towards their children than those women who have a healthy, supportive relationship with their partner (Mapp, 2006). Women who are depressed have a diminished ability to parent effectively; these mothers have difficulty communicating with their children and have more naturally negative interactions with them. The family environment of a depressed mother is often hostile, aggressive, and rejecting (Mapp, 2006). 
DOI: 10.21522/TIJAR.2014.06.01.Art002

ISSN: $2520-3088$

\section{Method}

To collect data the observation, qualitative and quantitative method will be used to establish the factors on the impact of Gender based violence on child development. My contention is that both quantitative and qualitative research approaches are appropriate for a case study in educational research (Strauss and Corbin, 1990; Patton, 2002), which deals with life skills. Both qualitative and quantitative methods are concerned with studying phenomena (Lbarkkin and Kurdziel, 2002). However, case study research is primarily concerned with gaining direct experience with a setting is intrinsically and exploratory endeavor (Mann, 2003). Thus, it has the potential for generating new theories and idea and is therefore particularly applicable to my study. I will collect quantitative data in the form of transcripts and descriptions while at the same time I will also collect data that could be measured and represented in numbers. However, all the quantifiable data is to be interpreted qualitatively. As early childhood educators, we all have our own philosophies and approaches to education. Our approach to teaching is created from a multitude of resources and probably includes knowledge from early childhood theorists, an understanding of child development and our experiences with children in different learning environments. It is worthy to seek information that would assist teachers, caregivers, parents to become practitioners that are more reflective in their daily rearing of child.

As a practicing teacher, I have an active interest in disseminating the information on prevention and the skills to reduce gender-based violence. This will provide technical and normative guidance for evidence-based gender-based prevention. It advocates for increased international support for and investment in evidence-based gender-based violence prevention.

\section{Discussion}

In Zambia, Gender based violence has become the order of the day. the most affected is the woman who is the care giver of the child. This violence is transferred to an innocent child who is going to have behavioural problems. The nation has been faced with such an overwhelming crisis that dramatic measures were called for, and large numbers of police officers, social welfare officers, doctors and ordinary people have been called to help in the eradication of this evil Gender based violence and deal with the massive prevention which has already had a major impact on child development. When a child is exposed to all forms of violence poses a new challenge. This brings a negative impact on the development of a child.

Every day in Livingstone Teaching Hospital (LTH) in Livingstone, there are women, girls and men who are struck down by violence and every day we are faced with the consequences of bad child behavior and poor performance in academic circles.

In order to eradicate Gender based violence, Enforcement Mechanisms and Support Systems have been put in place in Zambia, such as protecting children from violence exposure and strengthening families, counselling families, supporting families, protective factors, public awareness, community activities, positive parenting, intervention programs, and more.

This means that we need to Promote rights of women and girls, across the country so that it can be effective in achieving the desired goal, which is to improve the life style of a woman who is a care giver of a child.

According to Chidoori Rumbidizai the Government has also reviewed laws such as the penal code to increase protection of women and children from sexual violence and also developed the National Gender Policy 2014 based on the review of the National Gender Policy of 2000. The National Plan of Action on Gender Based Violence (NPA-GBV) 2010-2014 lays out the government's commitment to eliminate GBV. Civil society and several non-governmental organizations have played a pivotal role in ensuring adequate protection for women.

Gender based violence programmes is well received as is evidence from how fast it's spreading. The way to credit its contribution as an exercise is through research. Research will offer facts that can encourage our society to make informed decisions and for professionals to use it for the benefit of their clients. New knowledge can be used to formulate laws.

The societal effects of gender-based violence are often understood better when looking at the effects of the violence on children. The controversial issue of child custody might be a good start before 
discussing the overlap between violence against women and children. When women suffer violence in a partnership, children are also affected in different ways.

Children need their father, even if he is a batterer. Some abusers are good fathers and should have joint custody of their children.

Male children who see their father beat their mother are 7 times more likely to be violent as adults than those who did not witness such violence (Straus et al., 1981). Children need healthy role models. Unhealthy role models damage children now and in the future. Men who batter women are more likely to batter children physically, sexually, and emotionally. Their need for power and control of family members often stifles the healthy development of their children.

Nearly $90 \%$ of children who grow up in abusive homes witness the assaults. Nearly half of the batterers also abuse their children. (MINCAVA 2004: Family Violence Nursing Curriculum)

Gender based violence in young children in particular; the consequences may become lifethreatening extending in adulthood and cause health problems. The same children who are exposed to violence are at high risk of developing a series of behavioral, cognitive and emotional problems that may persist into adulthood.

A woman can experience violence through the factors such as poverty financial dependence, disability, homelessness or insecure status that can increase the risk of caring for the child.

According to the ministerial statement of 2017, "The ministry is committed to creating an enabling environment in which civil society organisations, faith based organisation, private sector and individuals can work and thrive and hence, contribute to the reduction of GBV cases and incidences of child marriage to make the lives of our people worth living".

Gender-based violence includes domestic abuse, rape and sexual assault, childhood sexual abuse, commercial sexual exploitation, stalking and harassment, and harmful traditional practices (e.g. female genital mutilation, 'honour' crimes and forced marriage). It predominantly affects women, although men too can be victims of abuse.

Children who are exposed to battering become fearful and anxious. They are always on guard, watching and waiting for the next event to occur. They never know what will trigger the abuse, and therefore, they never feel safe. They are always worried for themselves, their mother, and their siblings. They may feel worthless and powerless.

Children who are early exposed to violence grow up with anger, fear, guilt, shame, sleep disturbances, sadness, depression, and anger and are expected to keep the family secret; sometimes they do not even talk to each other about the abuse. Children from abusive homes can look good to the outside world, but inside they are in terrible pain. Their families are chaotic and crazy. They may blame themselves for the abuse thinking if they had not done or said a particular thing, the abuse would not have occurred. They may also become angry at their siblings or their mother for triggering the abuse. They may feel rage, embarrassment, and humiliation.

Children of abuse feel isolated and vulnerable. They lack attention, affection and approval. Because mother is struggling to survive, she is often not there for her children, because the father is so consumed with controlling everyone, he also is not there for his children. These children become physically, emotionally and psychologically abandoned.

Gender-based violence has become an umbrella term for any harm that is perpetrated against a person's will, and that results from power inequalities that are based on gender roles. Around the world, gender-based violence usually has a greater negative impact on women and girls.

Gender based violence can have serious and lasting effects on children's growth, development, health and wellbeing and contribute to health inequalities in adulthood.

Being a witness of domestic violence is especially stressful for children as they are deprived of the fundamental needs for safety and comfort and grow up in an atmosphere of fear and terror. Children feel helpless, unprotected, responsible, or partly to blame or they want to interfere and get injured themselves. Particularly when the woman is exposed to constant violence the consequences can be traumatic and this is transferred to an innocent child who is growing.

Witnessed or directly experienced violence has various effects on girls and boys. Such experiences can impair the emotional, physical and cognitive development of the affected children and in the case of chronic forms of violence or with very small children can lead to traumatic damages. Research found 
DOI: 10.21522/TIJAR.2014.06.01.Art002

ISSN: $2520-3088$

that $50 \%$ to $70 \%$ of children exposed to domestic violence suffer from posttraumatic stress disorder (Klotz 2000).

In the case of co-experienced partner violence, studies of child behavior disorders show outward directed reactions such as anxiety and aggressiveness ("Externalization"). However, most of all they show inward directed reactions such as intense depressiveness or fearfulness ("Internalization"; Kindler 2002). Kindler determined that compared to control groups, children affected by domestic violence show a five- fold risk of symptoms that require treatment (ibid).

According to Kerig (1998) regarding gender-specific differences indicates that girls are more inclined to feel partly responsible for violence, whereas boys feel a stronger sense of threat. Girls showed externalized symptoms in the immediate social environment but the danger of chronic externalization signs was thought to be higher for boys.

Evidence on the prevalence and forms of GBV has expanded rapidly in recent years, although data mostly come from high-income countries and are sparse in several regions. More population-based research is needed in order to create a clearer picture of GBV around the world. Currently there is very little research on the prevalence and complexities of some forms of violence like trafficking, rape, honor killings, child marriage and abuse, and violence in conflict settings. There is also a limited understanding of the various experiences a woman may have with GBV over her lifetime and what services and supports she might need at different points. More can be done to capture the range of experiences and their short-term and long-term health and social consequences for women. (Fulu, E., and L. Heise 2014).

It has come to light that very little has been done in terms of children exposure to violence and the impact gender-based violence has on child development. More studies need to be done in order to have comparable results from which conclusions can be made about the impact of gender on child development in Zambia.

In Livingstone town of Zambia, most women suffer gender-based violence. There are factors that lead to gender-based violence. Several factors that increase the risk of a man committing violence and the risk of a woman experiencing violence. This has to be established in order to get to the root cause.

\section{Summary}

The root cause of gender-based violence lied in unequal power relations between women and men. However, a variety of factors on the individual level, the family level, and at the level of community and society, often combine to raise the likelihood of violence occurring.

Children who are raised in abusive homes learn that violence is an effective way to resolve conflicts and problems. They may replicate the violence they witnessed as children in their teen and adult relationships and parenting experiences. Boys who witness their mothers' abuse are more likely to batter their female partners as adults than boys raised in nonviolent homes. For girls, adolescence may result in the belief that threats and violence are the norm in relationships.

The behavioral responses of children who witness domestic violence may include acting out, withdrawal, or anxiousness to please. The children may exhibit signs of anxiety and have a short attention span, which may result in poor school performance and attendance. They may experience developmental delays in speech, motor or cognitive skills. They may also use violence to express themselves displaying increased aggression with peers or mother. They can become self-injuring.

The study can contribute to the formulation of policies related to prevention of Gender based violence and in the strengthening of child development. By so doing this will improve the

Research into the nature and effectiveness of the programs that Zambians are already engaging into is important even as we look forward to the implementation of interventions related to impact of genderbased violence on young children.

\section{Results}

Parents bring up their children in different ways, which influence the children's, social, emotional and intellectual development. Some parents do not offer much on the moral and social values that a child needs to uphold acceptable social behavior of society. 
Early childhood Education enables all children to develop the skills that children require for their holistic development. These skills can easily attain through taking care of the children by keeping them away from early exposure of gender-based violence. Another way is by identifying causes and risk factors that lead to Gender based violence.

Also designing and testing interventions that are aimed at minimizing the risk factors of child abuse. Another way to prevent Gender based violence is by disseminating information about the effectiveness of interventions and increasing the scale of proven effective interventions.

Children must be reared in a loving and caring environment and distance them from early exposure to any form of violence. Let the children get motivated as they freely choose to participate and enjoy what they feel they can do without any interference from the parents or care givers. Children will therefore learn to work independently and they develop positive attitude'

Avoid Early Violence exposure it is not the right way of rearing the children. Just by talking and showing love between mother, father, family and the community at large. When you really care for them can reduce the neglect or child abuse, therefore children will definitely develop positive attitude and there are chances for building self-confidence and all other areas of child development.

Children, who experience gender-based violence, are mentally affected and fail to learn to work freely and independently. This lessens the opportunity for a teacher to carry out the opportunity to diagnose and assess the learning in a non-threatening situation.

\section{Conclusion}

This study intends to find out the consequences and prevention of Gender based violence on child development in line with promoting the wellbeing of the child. In carrying out the objectives to help as a yardstick to achieve the intended purpose, appropriate data-collecting instruments is be used to design in line with the objectives

The study aims at establishing factors whether parents, teachers, caregivers and the community help children to enhance child development by preventing Gender based violence. The researcher felt it worthy to seek information that would assist teachers, caregivers, parents and the community to become practitioners that are more reflective in their daily rearing of children. The study is further to provide information to policy makers to understand the consequences of Gender based violence $t$ and the importance of child development. This study is contributing to my understanding of the teacher's experiences as they progress through the training and implementation cycle in their classroom experiences. Schlechy (1990) stated "to improve schooling, one must invest in people, support people and develop people" (p.38). Educational practitioners can be liberated to improve their profession with opportunities that promote systemic, collaborative teacher research conducted in the authentic setting of the classroom. Educators can use teachers to uncover explanations to their own questions about the best way to avoid violence and improve on rearing children in a conducive environment.

As a practicing teacher, I have an active interest in disseminating the information on prevention and the skills to reduce Gender based violence and provide technical and normative guidance for evidencebased on prevention.

It advocates for increased international support for and investment in evidence-based child maltreatment prevention. It also provides technical

support for evidence-based child abused prevention programs in several low and middle-income countries.

"Global status report on violence prevention 2014", the report reviews the current status of violence prevention efforts in countries, and calls for a scaling up of violence prevention programs; stronger legislation and enforcement of laws relevant for violence prevention; and enhanced services for victims of violence. It is in this vein that this research finding will add to the body of knowledge and benefit others that may be in the same predicament as me. 
DOI: $10.21522 / \mathrm{TIJAR} .2014 .06 .01 . A r t 002$

ISSN: $2520-3088$

\section{References}

[1]. Achenbach, T. (1991). Manual for the Child Behavior Checklist, University Associates, Burlington, VT.Google Scholar.

[2]. Augustyn, M., Parker, S., Groves, B. M., and Zuckerman, B. (1995). Children who witness violence. Contemp. Ped. 12: 35-57.Google Scholar.

[3]. Baron, R. M., and Kenny, D. A. (1986). The moderator-mediator variable distinction in social psychological research: Conceptual, strategic, and statistical considerations. J. Personal. Social Psychol. 51: 1173-1182.Google Scholar.

[4]. Basic Behavioral Science Task Force of the National Advisory Mental. Health Council. (1996a). Basic behavioral science research for mental health: Vulnerability and resilience. Am. Psychologist 51: 22-28.Google Scholar.

[5]. Ellsberg, M., D. J. Arango, M. Morton, et al. (2015) Prevention violence against women and girls: what does the evidence say? Violence against women and girls 1.

[6]. The Lancet [published online]. 4. Garcia-Moreno, C., C. Zimmerman, A. Morris-Gehring, et al. (2015) Addressing violence against women: a call to action. Violence against.

[7]. Ministerial statement on Gender Based Violence in Zambia March 2017. Assessed on internet On 2nd November 2018. 


\title{
At Crossroads: Reflections on the Efficacy of the Southern African Development Community (SADC) in Conflict Resolution in Zimbabwe and the DRC
}

\author{
Article by Feddious Mutenheri \\ Texila American University \\ E-mail:feddious@gmail.com
}

\begin{abstract}
Since its formation in 1980, The Southern African Development Community (SADC) (formerly $S A D C C)$ has been confronted with a number of conflict cases within its membership. The conflicts include, but indeed not limited to, civil wars in Angola and DRC and political instability in Lesotho, Madagascar, South Africa and Zimbabwe. The Democratic Republic of Congo and the Zimbabwean conflicts are contemporary yet internecine test cases a propos the competence and relevance of SADC in providing the so-called "African solutions to African problems". SADC, through its various organs has been involved in the resolution of these conflicts. Nonetheless, SADC has found itself in intricate circumstances and perceptibly unsatisfactory principally as it dealt with Zimbabwe and the DRC. The paper traces the development of conflict in the DRC and Zimbabwe. It traces the historical performance of the SADC in conflict resolution in southern Africa. It is the aim of the paper to assess $S A D C$ performance in conflict resolution in the region, particularly in Zimbabwe and the DRC.
\end{abstract}

Keywords: SADC Efficacy, Conflict Resolution, Negotiation.

\section{Introduction}

Continued existence and relevance of organizations and institutions in general and SADC in particular, are predicated on their ability to effectively deliver on their aims and objectives. Failure to do so may spell doom or undermine the sustainability of such institutions. The effectiveness, efficiency and relevance of the Southern African Development Community in conflict resolution within the region have been put to test in Zimbabwe and the Democratic Republic of Congo. Arguably, SADC's failure to tackle these conflicts and oftentimes its droopy approach to solving these conflicts has raised many questions than answers on its relevance and more so its vigilance to deal with such. Often, skyscraping expectations had been placed in SADC to decisively consummate democratic transition in Zimbabwe. Conversely, SADC chose to be part of the crisis at least at the level of lack of progress there and its manifest bias by its officials in its decisions. In the DRC, SADC has been more of a spectator in the unfolding obdurate conflict rather than taking a leading role as the parent regional organization. SADC has had opportunities in both the countries to bring belligerents to the same table and recoup vanquished democracy in these scoundrel states. There is colossal need for reform in SADC's constitution, organs and policies, for it to be relevant in conflict resolution, peacebuilding and peacemaking in the region.

\section{The emergence of SADC}

In order to understand the performance of SADC in the resolution of conflicts within its region, it is very important to dissect its very origins. The genesis of SADC lies in the 1960s and 1970s, when the leaders of majority-ruled countries and national liberation movements coordinated their political, diplomatic and military struggles to bring an end to colonial and white-minority rule in southern Africa. The immediate forerunner to this organization was the Frontline States which was a very much informal grouping. This grouping was predicated on political and security concerns during the time. Its forerunner in the socio-economic realm was the Southern African Development Coordinating Conference (SADCC) adopted on 1 April 1980. (http://en.wikipedia.org/wiki/SADC).

The organization kicked off with nine members. Membership in the Frontline States and SADCC sometimes differed. Currently SADC comprises fourteen member countries namely Angola, 
Botswana, Democratic Republic of Congo, Lesotho, Mauritius, Madagascar, Malawi, Mozambique, Namibia, Swaziland, South Africa, Tanzania, Zambia and Zimbabwe. From the above submissions, it is therefore safe to argue that this evolving organization was a coterie of old friends bound by a common history and therefore bound to each other in many circumstances.

SADCC or the conference as it was known, was formed with four principal objectives, namely, (i) to reduce member states' dependence, particularly, but indeed not only, on Apartheid South Africa; (ii) to implement programmes and projects with national and regional impact; (iii) to mobilise member states' resources, in the quest for collective self-reliance; (iv) and to secure international understanding and support.

With the emanation of new problems and also the expansion in the membership (Namibia joined later), the SADCC was transformed into a more "relevant" organization aimed at socio-economic cooperation and political and security cooperation. On 17 August 1992 the founding fathers adopted the SADC Treaty. Subsequently, after the South African democratic elections in 1994, the Frontline States was dissolved. At that time subsequent efforts to place political and security cooperation on a firm institutional footing under SADC's umbrella failed.

(http://en.wikipedia.org/wiki/Southern_African_Development_Community).

On 14 August 2001, the 1992 SADC treaty was amended. The grouping adopted objectives that sought to show the changes envisaged by the member states. Its objectives were to:

1. Achieve development and economic growth, alleviate poverty, enhance the standard and quality of life of the people of Southern Africa and support the socially disadvantaged through regional integration;

2. Evolve common political values, systems and institutions;

3. Promote and defend peace and security;

4. Promote self-sustaining development on the basis of collective self-reliance, and the interdependence of member states;

5. Achieve complementarity between national and regional strategies and programmes;

6. Promote and maximise productive employment and utilisation of resources of the Region;

7. Achieve sustainable utilization of natural resources and effective protection of the environment;

8. Strengthen and consolidate the long standing historical, social and cultural affinities and links among the people of the Region.

The amendment heralded the overhaul of the structures, policies and procedures of SADC. One of the changes was that political and security cooperation was institutionalized in the Organ on Politics, Defense and Security (OPDS). It has been argued that as one of the principal SADC bodies, it became subject to the oversight of the organization's supreme body, the Summit, which comprises the heads of state or government. (http://en.wikipedia.org/wiki/Southern_African_Development_Community). However, it is clear that the principles that drive the organization have not been evolved. The new organs and policies, it would seem, only serve to protect heads of state chiefly because they are all from the liberation ruling parties.

One important objective of the SADC is its desire to promote and defend peace and security. This objective is also consolidated by another equally important objective that of evolving common political values, systems and institutions. The above objectives have been pursued across Southern Africa especially in conflict zones. But this has been done with mottled success particularly in Zimbabwe and the DRC. This can be explained by a few but very strong factors.

Firstly, there is no explicit objective in the SADC Treaty that predisposes it to effective conflict resolution. This means that, conflict resolution by the SADC is always only in pursuance of other objectives. In other words, conflict resolution for SADC is not an end in itself and neither is it a means to some end. It is simply an incidental adventure thrust upon SADC as the principal intergovernmental organization within that region. This is problematic because it does not empower SADC to make bold and legally binding decisions in conflict situations.

Secondly, SADC has been duplicated by a number of other regional organizations. Some member countries are not bound only by SADC but by other organizations within the same region. This undermines SADC. According to Wikipedia one significant challenge is that member states also participate in other regional economic cooperation schemes and regional political and security 
cooperation schemes that may compete with or undermine SADC's aims. For example, South Africa and Botswana both belong to the Southern Africa Customs Union (SACU), Zambia is a part of the Common Market for Eastern and Southern Africa (COMESA), and Tanzania is a member of the East African Community

(EAC). (http://en.wikipedia.org/wiki/Southern_African_Development_Community).

Thirdly, it is arguable that SADC's decisions are affected and influenced more by what can be said to be 'vague objectives' within its constitution which either make it difficult to take firm decisions in conflict resolution or to take wrong decisions altogether in pursuit of such skewed objectives. One example of such objectives is based on "strengthening and consolidating the long standing historical, social and cultural affinities and links among the people of the region". In pursuance of this objective, it is arguable, that SADC has made some dangerous decisions devoid of pragmatism, only pursuing comradeship.

\section{Theoretical framework}

Conflict resolution is a range of processes aimed at alleviating or eliminating sources of conflict. According to Wikipedia.com, the term conflict resolution is sometimes used interchangeably with the term dispute resolution. Processes of conflict resolution generally include negotiation, mediation and diplomacy. The processes of arbitration, litigation, and formal complaint processes such as ombudsman processes, are usually described with the term dispute resolution, although some refer to them as "conflict resolution." Processes of mediation and arbitration are often referred to as alternative dispute resolution. (http://en.wikipedia.org/wiki/Conflict_resolution).

There is considerable controversy about definitions and terminology in the field of conflict resolution. This may be partly because the field is multidisciplinary. Academics and practitioners are found within diverse disciplines including political science, international relations, law, and psychology. (http://en.wikipedia.org/wiki/Conflict_resolution).

Many of the definitional concerns spring from diverse definitions of the terms conflict and dispute and resolution. The term conflict has been defined as "intense interpersonal and/or intrapersonal dissonance (tension or antagonism) between two or more parties based on incompatible goals, needs, desires, values, beliefs, and/or attitudes." (Ting-Toomey: 1985) Disputes have been defined as conflicts that have become particularized around a specific issue or issues. (Abel: 1973). Some conflicts may not become manifest as articulated disputes. Thus, "conflict resolution" tends to refer to processes that address the sources of conflict so as to prevent them from escalating or eliminate the conflict altogether. The term "dispute resolution" refers to settlement of disputes and complaints, which may or may not address or eliminate the sources of the conflict. (http://en.wikipedia.org/wiki/Conflict_resolution). It is within this context that SADC's efforts in Zimbabwe can be understood. In Zimbabwe the whole situation can be characterized as dispute resolution to a larger extent but clearly, I find this very problematic especially as it fails to deal with the very causes of conflict.

There are many tools available to persons in conflict. How and when they are used depends on several factors (such as the specific issues at stake in the conflict and the cultural context of the disputants). The list of tools available to practitioners includes negotiation, mediation, community building, advocacy, diplomacy, activism, non-violence, critical pedagogy, prayer and counseling. In real world conflict situations, which range in scale from kindergarten bullying to genocide, practitioners will creatively combine several of these approaches as needed. Additionally, practitioners will often specialize in a particular scale (e.g. interpersonal, community or international), or a particular variety of conflict (such as environmental, religious or organizational), and repertoires of tools they find most useful. ((http://en.wikipedia.org/wiki/Conflict_resolution)

\section{Background to conflict in the DRC}

The current conflict in the DRC has its roots in the 1990s. After the Rwandan genocide of 1994, Congolese President Mobutu allowed the Interahamwe (a group of Hutus responsible for the genocide) to take refuge in the DRC. The interahamwe launched attacks into Rwanda from the Eastern Congo, triggering the Rwandan Army's invasion of the DRC. 
(http://www.getloud.ca/en/gpi_issues.asp?id=12). In 1996, the Rwandan and Ugandan-backed Alliance of Democratic Forces of Congo- Zaire (ADFL) marched on to Kinshasa. Mobutu fled, and Laurent-Kabila declared himself President. In July of 1998, Ugandan and Rwandan troops left the DRC at the request of Kabila; however, Rwandan troops invaded the DRC a few weeks later. (http://www.getloud.ca/en/gpi_issues.asp?id=12). Kabila turned to the Southern African Development Community (SADC) for help. Zimbabwe, Namibia and Angola sent troops to help ward of the Rwandan and Ugandan armies. By 1999, Rwanda, Uganda, and the Congolese rebel groups that they sponsored managed to control one third of the DRC.

In July 1999, the Lusaka Accord was signed by the six warring nations (Democratic Republic of Congo, Angola, Namibia, Zimbabwe, Rwanda, and Uganda) and rebel groups in an attempt to stop the civil war. The Lusaka Accord called for a cease-fire, the deployment of UN peacekeepers and the disarmament and repatriation of all armed foreign groups. Unfortunately, all parties have not consistently implemented the treaty.

Although officially there has been a cease-fire since 2003, intermittent fighting continues on the ground. In March 2004, there was an attempted coup against the government in Kinshasa. Throughout the war, many nations and multinational corporations have exacerbated the conflict by exploiting the DRC's rich natural resources for their own gain.

The largest war in modern African history, the Second Congo war, directly involved eight African nations including the DRC, Zimbabwe, Angola, Namibia, Uganda, and Rwanda, as well as about 25 armed groups. Most of the countries involved were member states of SADC. However, they were involved more on individual basis than under the SADC banner. What is more, some countries such as South Africa did not join to support the SADC countries. If anything, wide reports then were that they clandestinely supported the rebel armies.

As with most conflicts, civilians have suffered immensely. The International Rescue Committee (IRC) has attempted a few surveys during the conflict. The IRC found that since the war started in 1998:

1. Some 5.4 million people have died in this conflict, either by the bullet or other social consequences of the war

2. It has been the world's deadliest conflict since world war II

3. Although $19 \%$ of the population, children account for $47 \%$ of the deaths

4. Some 45,000 continue to die each month. (Shar:2008)

Oxfam also noted that "the international community is essentially ignoring what has been deemed 'Africa's first world war.' The DRC remains a forgotten emergency. Falling outside of the media spotlight, and experiencing persistent shortfalls in pledged humanitarian aid, the population of the DRC has been largely abandoned to struggle for their own survival." (Oxfam: 2000)

\section{Background to conflict in Zimbabwe}

The conflict in Zimbabwe dates back to around 1998, when the Mugabe regime embarked on a drive to win back its diminishing support base. Food riots, student demonstrations and workers' strikes had become the order of the day owing to economic meltdown in the country at the time. Also, the veterans of the liberation war were growing impatient with the government's unfulfilled promises namely restitution of land to the landless and recompense for their war efforts during Second Chimurenga. The crux of the matter: opposition to the government was swelling.

To salvage the slipping political support, Mugabe embarked on controversial policies both domestically and abroad. Abroad, he launched an unjustified intervention in the Democratic Republic of Congo. More than 11, 000 troops were committed to this cause. The intervention has been criticised for its insurmountable economic cost. At home the Mugabe regime embarked on populist and destructive policies to hang on to power.

Firstly, he angled for the appeasement of the veterans of the liberation war. To that end, he awarded unbudgeted gratuities of Z\$50, 000 each for their participation in the war. This induced untold economic shocks. The economy of Zimbabwe continued to slide sharply into recession. Opposition to Mugabe increased. 
Secondly, upping his populist tempo at home, Mugabe began the process of confiscating white owned farms. Party loyalists benefited. By the year 2000, the land reform exercise had taken a nasty route. White owners of land were violently displaced by party functionaries with reckless abandon.

In 1999, the Movement for Democratic Change (MDC) was born. The party was a culmination of people's struggles against a spiraling cost of living, against dictatorial tendencies by the regime and an innate and inescapable outcome of the third wave of democratization ${ }^{\mathrm{i}}$ in Africa, given the conducive conditions in Zimbabwe at the time. Unfortunately, the Mugabe regime instead of tackling the MDC as political opposition, they set on a war path to destroy the movement which they branded names such as, enemies of the state, puppets of the west, zvimbwasungata (surrogates of imperialism), gays of Tony Blair e.t.c. In the 2000 constitutional referendum, ZANU (PF) government was defeated by pro-opposition forces that were against a skewed draft constitution. Strictly speaking, the February 2000 plebiscite defeat ignited conflict between Mugabe and the opposition.

Since the June 2000 elections, Zimbabwe elections became axiomatically characterized by violence, accusations of gerrymandering, vote rigging and assassination plots. Mugabe's legitimacy was thrown into the abyss. Two points of power had emerged: on one hand was the neo-liberal MDC led by Morgan Tsvangirai and on the other hand the neo-nationalist ZANU (PF) led by Mugabe. Their confrontation climaxed with each major election. This called for intervention by the regional body, SADC.

\section{SADC in Zimbabwe and the Democratic Republic of Congo}

SADC mediation in Zimbabwe was conceived at an urgent SADC summit held in Tanzania in March 2002, when Thabo Mbeki (South African president) was appointed as mediator in the Zimbabwean crisis in order to manage her political crisis. The result area to this mediation was to help the two parties come to a political settlement after the preceding violent and divisive election. While SADC had shown the required leadership by focusing its attention on Zimbabwe, It is widely agreed that SADC failed in its judgements and decisions. This brings to the fore the question: Has the SADC role in Zimbabwe been actively positive or passively negative? Below I outline how SADC complicated rather than resolve problems faced by Zimbabweans.

SADC's efficacy in its dreary conflict resolution efforts in Zimbabwe can better be explained by a number of features. These can be précised as, but not relegated to, SADC's bond with ZANU (PF) and its leader Robert Mugabe, its pessimistic perception of the MDC and its President Morgan Tsvangirai, the intricate state of affairs in SADC member countries, and the facade of championing "Pan-Africanism". Below, I expound on each of these four factors and how they have largely prejudiced the conduct of SADC and therefore its disappointing performance in resolving the crisis in Zimbabwe.

Firstly, it is important to analyze the role of SADC in dealing with its member states from an understanding mentioned above: that it is a coterie of comradeship. Furthermore, the majority of SADC's membership is still ruled by Liberation War movements e.g. ANC in South Africa, SWAPO in Namibia, MPLA in Angola, FRELIMO in Mozambique and ZANU (PF) in Zimbabwe all of whom remain friends amongst and between themselves. These movements led uprisings against white supremacy in their countries. They organized against imperialism in this part of the continent. These movements successfully executed the struggle against colonialism through networking. Such a common history is to an outsized extent responsible for the decisions that SADC and its Heads of State have made. It is therefore not an exaggeration to affirm that their historical affinities far outweigh any present or future challenge to their hegemony as long as they exist.

According to Georgy, "SADC is made up of a group of leaders that are friends of President Mugabe. Many of them have been in power for a long time and do not respect democratic decisions,"(Michael Georgy, From Mail \& Guardian (SA), 11 November 2002). Evidence abounds to support the above assertion. The 2002 presidential elections were violently conducted in a mode that had not been experienced in the post independence epoch since the Matebeleland massacres. ZANU (PF) militias, partisan army and police and the secret agents were unleashed to brutalise all dissenting voices in a grotesque and unimaginable fashion. There was an international outcry to cease the violence. While the opposition, civic society, and international organizations such as the 
Commonwealth and European Union declared the presidential election as not free and fair, surprisingly, SADC and the African Union explicitly endorsed Mugabe regime's actions. In this manner it is with merit to argue that the SADC served only to appease a friend and legitimize a wholly and evidently violent, unfair and non-free election.

Secondly, since the emergence of the MDC in 1999, Mugabe and his party merchandised the idea that the Movement for Democratic Change and its President Morgan Tsvangirai were puppets of the west designed to effect regime change so as to "reinstitute" white imperial interests in the country. Peddling of such emotive and dangerous lies merited to invoke the sad memories of the armed liberation struggle and therefore win conservative support at home and the palpable buttress by regional leaders. That ruse seemed to stick even within the SADC. Ironically, Mbeki as leader of the regional power, South Africa, led all efforts to discredit Tsvangirai while at the same he was supposed to be an impartial SADC mediator. He played a major role in the 2005 MDC split. The above affirmation is corroborated by Maingire when he stated that: "On one side is the involvement of President Thabo Mbeki of South Africa in a plan to wrestle power from Morgan Tsvangirai and put the MDC under the control of Welshman Ncube... Mbeki is believed to be uncomfortable with a tradeunion backed opposition party unseating ZANU (PF) in a similar fashion to what became of Zambia when Fredrick Chiluba ousted Kenneth Kaunda. Mbeki finds a serious threat to his ANC political survival..." (R. Maingire, The Untold Story of the MDC, Thursday 9 August 2007, (The Zimbabwean.Com).

Morgan Tsvangirai was vividly aware of this negative perception and its consequent actions. He had suggested the same when he wrote to Mbeki, ... It was suggested that you were again in contact with a member of my National Executive, Secretary-General Mr. Tendai Biti. This interaction is reminiscent of that which happened prior to the break up of the MDC in October 2005.1 respectfully submit to you that such "private" meetings contributed to the misunderstandings that later led to a split in our organization... (http://www.thetimes.co.za/PrintEdition/PDFs/TsvangiraiLetter.pdf.)

Notwithstanding the above, it has remained that, the SADC regional leaders have leaned heavily against the democracy seeking Tsvangirai than they have rebuked the dictatorial Mugabe. It is not surprising that even when Tsvangirai won the March 2008 four-tier elections, which were endorsed as free and fair by SADC organizations and member states and the African Union and its organs, SADC heads of state chose to side with and cuddle Mugabe. Pressure was made to bear on Tsvangirai in all SADC mediation resolutions. A case in point was the ruling by SADC that the MDC co-manage a ministry with ZANU (PF), an unprecedented arrangement the world over. After the SADC summit Whande asserted that,

...instead of helping the people of Zimbabwe to regain their moral high ground and political imperative, SADC leaders are now ganging up against us. African leaders are a disgrace and SADC are worse. As is being confirmed by Somalia, Darfur, Zimbabwe and DR Congo, there are no African solutions to African problems. (T. Whande, http://www. swradioafrica.com).

Thirdly, the political state of affairs in the SADC member states can help better understand SADC decisions, and therefore its effectiveness or lack of the same in resolving the decade long political crisis in Zimbabwe. There remains a marked paucity of democratic practice within these member states. Swaziland, Lesotho, Namibia, The DRC, Angola and Malawi as cases have generated a lot of debate as to whether democracy can work in Africa. Allegations of election rigging, primitive rule (in Swaziland and Lesotho), armed conflict, stolen elections and lack of legitimacy by the leaders are negative benchmarks in southern African debate on democracy. These, no doubt, affect SADC decisions and effectiveness in her midwifery role to the rebirth of a peaceful and democratic southern Africa.

Lastly, "Pan-Africanism", across Africa, has been strategically used as a mask while depicting opposition parties as western surrogates, unpatriotic and therefore divisive. Pan-Africanism calls for a politically united Africa. (http://en.wikipedia.org/wiki/Pan-Africanism). In this vein, patriotism has been sequestrated, monopolized and personalized to mean automatic support of ruling parties and often times their antiquated philosophies, all of which are believed to be the repositories and champions of the African dream of a united Africa. MDC and its leaders have been major victims of 
this hoax while ZANU (PF) and its corrupt leaders have benefited from the same. This belief however should be fanatically challenged.

Opposition parties are health to any democratic dispensation. Firstly, they hold the executive to account. However, in Zimbabwe, this has made them enemies of government simply because they exposed all indecent government officials' activities. Secondly, they provide an alternative government. All citizens of a country should be allowed to choose whom they want or not to govern them. The Mugabe regime has resorted to dictatorship, where as an election loser on March 292008 , he clearly asserted that "the gun is mightier than the pen" referring to elections as means of choosing one's leaders. This was unpatriotic and a defeat of democracy.

It should therefore be asserted that no-one individual, group or society can monopolise patriotism. After all, it depends on who defines patriotism? For whom patriotism is defined? And for what purposes that patriotism is being defined by the same? We submit that patriotism is a value which is subjective when used against opposition. Opposition parties such as the MDC can equally be patriotic or even more patriotic than the ruling parties. For the MDC, they, represent aspirations of millions of Zimbabweans as reflected in the national elections where the MDC President won the confidence of the majority of all Zimbabweans.

According to Dahlen and Sandvand (2005) The DRC became a member of SADC in 1990, and the organization has been profoundly involved in the peacemaking efforts in the conflict. However soon after the ouster of former Zaire strongman, Mobutu Sese Seko and the ascension to power of Desire Laurent Kabila SADC was bound to be seriously seized with the task of conflict resolution in that country. In August 1998, the SADC Summit 'committed itself to seek an end to the military conflict immediately'. (http://www.sadc.int/archives/read/news/236).

However, since that time, the DRC conflict did not invite enough attention and collaborated effort by SADC countries in resolving the conflict. What has been identified is a incoherent and piecemeal attention to the conflict by a mother organization which is supposed to take a lead in the resolution of the conflict. A number of reasons can be proffered for this lackadaisical approach to solving issues in the region.

Firstly, it is the lack of trust for each other by the member states and some longstanding amityenmity dichotomies. This is corroborated by Francis who posited that, "SADC peacekeeping intervention... is based on ad hoc improvisation, often its deployment is based on flawed military assessment and driven by the amity-enmity of the geo-political co-operation." (Francis: 2006).

Struggles for regional dominance are a factor that cannot be underestimated in analyzing the reasons why SADC has not been effective in the conflict resolution in the DRC. Zimbabwe and postApartheid South Africa have been pitched for a long time in what can be aptly called a battle for regional dominance. According to Mutenheri (2009).

This rivalry protruded into the post apartheid era during Mandela's tenure. The relationship between South Africa and Zimbabwe degenerated into a political wrestling for control of the region. In 1997 Mandela and Mugabe had a highly publicized show-down over the status and functions of a regional security organization, the Organ on Politics, Defense and Security within SADC. Mugabe wanted the Organ to operate as an autonomous body under his control, something vehemently opposed by Mandela.

Mutenheri further noted that; This competition and battle for supremacy climaxed when Zimbabwe militarily intervened in the DRC in 1998. For South Africa this move by the Zimbabwe government, undertaken in the name of $S A D C$, was viewed as placing the organization in risk and challenged South Africa's leadership aspirations in the region. The two countries were also at odds over the participation of Congolese rebels in national peace talks, with Mandela favoring their inclusion but Mugabe dead set against it.

No doubt, the failure of SADC can also be explained by the fact that the DRC and its neighbors have not created conditions necessary for understanding. According to Whande, 'DR Congo has the luxury to present Africa with an encore of the mindless violence against itself with the help of other neighboring countries, not to mention Zimbabwe and Angola who are already in the DR Congo. (T. Whande: 2 November 2008) 
One could also argue that the geographical location of the DRC within the context of SADC has alienated her from SADC that it has brought her closer. DRC is more geographically divorced from the SADC member states and generally that expends the interest of the member states to fixate themselves with a member state which is so distant and does not provide any geo-political advantages.

\section{Conclusion}

From the foregoing it can be averred that the performance of SADC in conflict spots in the region is a hotchpotch of failure, 'lukewarm' results, malfunction and disenchantment. Where they have produced optimism, it has always been cautious. The dragging and prolonging of resolution processes by SADC has been driven by such factors as the desire to please fellow leaders, struggles for regional dominance, and failure to reform, aspects devoid of any principle. The efficacy of SADC measured on the criteria of relevance, effectiveness, sustainability, principle and pragmatism is still a far cry from achieving the goals for which it was formed, particularly conflict resolution. SADC as evidenced by its decisions, actions and involvement in Zimbabwe has shown that it is still hostage to past heroworship of liberators like Mugabe oblivious of the fact that the region should be progressive to embrace the aspirations and values of a free world based on democratic values. The emphases here being that SADC should take the lead to rein in errant leaders, enforce democratic principles and ensure sustainability of the same. The performance of SADC in DRC has also raised questions as to whether the organization is relevant or is part of the problems in the countries concerned. The divisions in approaches to deal with the conflict and the droopy approach to intervention put paid to the widely held belief that SADC is a toothless dog devoid of strategies for conflict resolution in the region. There is therefore need for a paradigm shift by SADC if it is to deal decisively with tyrants and avert escalation of conflicts in the region.

\section{References}

[1]. Dahlen. I. A. S, SADC and the war in the Democratic republic of Congo: a critical view on the role of a regional organization in a conflict-torn memberstate, I.A.S. Dahlen, 2005, 82.

[2]. Feddious Mutenheri, South-South Co-operation or Sub-Imperialism: South African "Quiet" Diplomacy, SADC Docility, and the Underdevelopment of Zimbabwe. Journal of Sustainable Development in Africa. (unpublished).

[3]. Francis. D, Uniting Africa: Building Regional Peace and Security Systems, 2006, Google Books.com.

[4]. Oxfam, A Forgotten War-A Forgotten Emergency: The Democratic Republic of Congo, a Policy Paper, December 2000, provides many details and statistics, as well as criticism of the lack of international support.

[5]. Richard Abel, "A Comparative Theory of Dispute Institutions in Society" (1973) 8 Law \& Society Review 217 at 217.

[6]. Shah. A, The Democratic Republic of Congo, Global Issues, Thursday, March 27, 2008.

[7]. Stella Ting-Toomey et. al, "Toward a Theory of Conflict and Culture." In Communication, Culture and Organizational Processes, Thousand Oaks, CA: Sage, 1985, at 72.

[8]. http://en.wikipedia.org/wiki/SADC.

[9]. http://en.wikipedia.org/wiki/Southern_African_Development_Community.

[10]. http://en.wikipedia.org/wiki/Conflict_resolution.

[11]. (http://www.getloud.ca/en/gpi_issues.asp?id=12).

[12]. http://www.thetimes.co.za/PrintEdition/PDFs/TsvangiraiLetter.pdf.

[13]. http://www.swradioafrica.com.

[14]. http://www.sadc.int/archives/read/news/236).

${ }^{\mathrm{i}}$ Feddious Mutenheri is a Zimbabwean and tutor in Development Studies at Livingstone Kolobeng College, Box 403388, Block 8, Gaborone, Botswana. Cell: +26775092190, e-mail: feddious@gmail.com

${ }^{i}$ Third wave of Democratization refers to what is considered by some to be democratic transitions and democratization throughout much of the developing world. The phrase however, has come under criticism, largely by those who stress that so called democratic transitions are little more than 
Texila International Journal of Academic Research Volume 6, Issue 1, Apr 2019

transitions to semi-authoritarian rule, as demanded by the international realities of a post-cold war world. 


\title{
The Impact of Technology in Public Sectors Workers' Performances in Nigeria: Case of Federal Ministry MDAs and Agencies
}

\author{
Article by Fred-Osogu Obioma \\ Ph.D, in Management, Texila American University, Guyana \\ E-mail: fredobioma@yahoo.com
}

\begin{abstract}
This paper provides information about the worker's productivity and performances in Nigerian public service operations. It clearly outlines the productivity and performances decrease that faces employees inside of workplace of Nigerian public sector. The article further argues that the deficiency in the perfect usage of technology, computer systems and communication networks (internet) is lack of interest of the organization to prepare a training schedule. It is the failures of respective Ministries and Agencies (Heads of Affairs) to train the staff on the use of technology in work place. These factors are among others which effect on the productivity and performances causing the employees to be less productive at their workplaces. Consequently, this has the negative effect on the economy. In addition, the decrease of individual productivity and performances is evidenced via the outcome of the survey of individuals who has shortage of interest of the management to prepare a time training schedule and system of computing to work within the country of Nigeria. Therefore, the paper recommends measures which should be taken to improve productivity and performances of workers by training them on Computer technology. The training can be inside or outside in the organization, which could lead to improvement in the input loutput performances of individual work staff, all workforce and economic development of Nigeria in general.
\end{abstract}

Keywords: Technology; Training; Computing System; Internet; Workers Performances \& Productivity.

\section{Introduction}

Over the past many decades there are dramatic changes within the forms of technologies offered to businesses whether public or private. The speedy development and diffusion of recent data technologies such as computers, communications and networks has altered the production process in several workplaces. In conjunction with these basic changes in the physical capital of firms or organizations, it is jointly and widely believed that the introduction of those new technologies has altered the structure of employment [Mark D, Timothy D, Kenneth T \{1997\}]. Productivity has increased in workplaces where computer usage is applied. This is unlike most of the ministries and agencies in Nigeria. Employers and policymakers have emphasized the importance of talent and skills upgrading of employees and long learning so as to deal with accrued pressures elicited by technological modification and economic process (Example European Commission, 2007).

There exists an oversized literature showing that the accumulation of human capital through the overall education system plays a vital role in explaining long financial gain but differences between wealthy and poor countries is also in modernization of operations with new developments in science and technology. Abundant less work exists on the application of training on computers. It usually brings specific skills from their employees to step up work preferences. In training on computer, it is important there is a distinction between identity, firm or organization's specifics and general training for the purpose of the required job and its output. General training ends up in skills that are equally applicable to alternative corporations whereas skills acquired through firm-specifics coaching area unit lost once the skilled worker leaves the firm or organization that provided coaching. By excellent competition within the market, employees ought to get hold of prices of general training and recoup these prices by earning higher wages. Once training is particularized, firm pay (part of) the training costs. However, in varied cases companies offer and get hold of training which is general in nature. They show how it could be explained by labour market imperfections. Particularly, a necessary condition for organizations to get hold of general training is that wages increase less steeply in training than productivity. This can 
be stated as a compressed wage structure which may be caused by frictions within the market like search prices, informational asymmetries, potency wages and labor markets establishments inform of unions or the presence of earnings laws. With a compressed wage structure, training will increase the marginal product of labour over wages that creates incentives for the firm to take a position in training. Like the instances above, in recent years that computer power itself has enabled researchers to statistically interrogate large scale datasets on firms, organizations and providing some more solutions to the issues of large volume storage and retrieval [John V, Reenen RS (2005].

The importance of skill upgrading of workers and lifelong learning in order to cope with increased pressures induced by technological change and globalization would amount to nothing if the computer knowledge could not be applied in the operations (European Commission, 2007). However, while there are researched literatures showing that the accumulation of human capital through the general education system that plays a crucial role in explaining long run income differences between rich and poor countries. Much less work exists on the effects of training provided by firms, often requiring and based on specific skills from their workers [Konings J Vanormelingen S (2010].

\section{The scope and structure of this study}

This study is structured as follows: 1. a brief review of the main trends in the empirical literature used in the analysis of the impact of technologies (computing and communications) on productivity or performance, 2. The important of training employees on the use of computer technology in workplace for productivity and performance increase. 3. Reports and discusses on the results of the statistical analysis. 4, the last section concludes, highlighting the main implications of our results findings. Finally, 5 concludes and recommends.

\section{Review of relevant literature}

The works of research studies carried out in US by Kristen and Lee, [2014]; they have validated the fact that workers on their productivity are affected by the Internet. They reported that the six in ten approximately $61 \%$ of American workers who strongly agree on use of the internet say email is "very important" for doing their job, and 54\% agreed say it is important (the same about) the internet. Far fewer workers describe landline phones (35\%) or cell phones and smartphones (24\%) as "very important." Just 4\% say social networking sites like Twitter, Facebook or LinkedIn are "very important" to their work. According to Kimmo [2012] to increase productivity, the employer should have up-todate internal communication guidelines and organize training and other support for employees, particularly when new communication tools are taken into use. More than that, including sharing, archiving relevant information and documents also should be available for co-employees as a common practice. Additionally, to evaluate the degree of workers' skills and recording the output at work, it is possible to estimate the impact of the training on productivity and performances at the workplace. This therefore led to the question why computer training for employees which Cecile Peterkin (2017), Milton Kazameyer (2007) and Bill Gates, the founder of Microsoft answered. Their detailed responses are stated here under.

\section{Why computer training for employees is highly recommended}

2017 Cecile Peterkin a computer training specialist stated that training employees in computer skills is essential in the workplace. The importance can be viewed in two ways. Basically, job applicants need to have computer training in order for them to become more valuable to their potential employers, and also to enable them to find jobs that pay well. Secondly, companies need to include computer training in their training program for new employees. When everyone at work is proficient in using computers, the company is likely to benefit from high employee productivity and efficiency. Explaining further, Cecile Peterkin stressed the importance as follows;

\section{Important job skill}

Computer skills are an important requirement for many types of jobs. As a job seeker, you will realize that in almost all office jobs out there, applicants are required and even expected to have excellent computer skills. You need to have at least basic data entry or typing skills. You should also have a good understanding of how an operating system is used. 
Most of the tasks in the office also require employees to have familiarity with some important and useful software and programs, too. And even in some non-office jobs, a bit of computer knowledge and training is required. In short, computer skill is essential. If you don't lack such skills, you will succeed in your job search and high performances productivity on the assigned jobs.

\section{Training on the job}

Basic training on how to use computers provides a strong foundation which workers can develop new skills on. In most cases, companies offer such training to their new employees. For instance, newly hired workers need to know how a proprietary software program is used. Managers can't expect new personnel to know how to use their specific software or programs. Thus, the organization has to invest in the training of their workers, especially the newcomers.

\section{Increased productivity}

As mentioned earlier, basic computer training is a way for companies and businesses to increase their employees' productivity. Employee training can also be conducted on computers. This will help streamline the entire training process, thus allowing the company to save on time and money.

\section{Employee development}

Basic computer training will obviously help employees develop skills that they need to be effective in their jobs. But aside from the technical skills that can be enhanced through computer training, the more important benefit of computer training is in the way it boosts employees' confidence. Personal development is a very important factor that can lead to worker satisfaction and increased productivity. When employees feel that they are learning something from their job, they are likely to stay and stick with the company.

Providing basic computer training is highly recommended by business administrators' and experts. Business consultants would always advise managers and company owners to invest in employee training, such as computer training, because at the end of the day, it is the business or the organization that benefits from the skills of its workers.

\section{The organizational concepts of productivity and performances}

Productivity and performance characterize the efficiency of productive output of workers, which is expressed by the number of products or services par unit time. Performance is the value of functional abilities of the body characterized by the quantity and quality of work at maximum intensity or activity. The type of performance and frequency of its changes are related to the duration of human and her Functional State (FS) phases outlined works [Doroshev VG; 1988] and Gavrilov et al. [2008].

According to Rohan and Madhumita [2012] companies, today are forced to function in a world full of change and under various complications and competitions. It is more important than ever to have the correct employees at the correct job with the right qualification and experience in order to survive the surrounding competition.

The successful and prosperous future of an organization is dependent on its skilled, knowledgeable and well-experienced workforce that is why training is a fundamental and effectual instrument in the successful accomplishment of the organizational mission, vision, goals and objectives. Training not only improves them resourcefully, but also gives them a chance to learn their job virtually and perform it more competently thereby hence service delivering, increasing firm's productivity and performance. Training has been an important variable in increasing organizational productivity, according to the Researchers' comments like Colombo and Stanca [2008], Sepulveda [2005], Konings and Vanormelingen [2009].

\section{The importance of computer in business organization}

Computers have become such an integral part of our lives because we rely on them for numerical calculations, storage of data, communication, and technological processes. Computers are simply complex counting devices. The abacus was an ancient computer which used beads to solve mathematical problems. Business software or a business application is any software or set of computer programs used by business users to perform various business functions. These business applications are 
DOI: $10.21522 /$ TIJAR.2014.06.01.Art004

ISSN: $2520-3088$

used to increase productivity, to measure productivity and to perform other business functions accurately.

By and large, business software is likely to be developed to meet the needs of a specific business, and therefore is not easily transferable to a different business environment, unless its nature and operation is identical. Due to the unique requirements of each business, off-the-shelf software is unlikely to completely address a company's needs. However, where an on-the-shelf solution is necessary, due to time or monetary considerations, some level of customization is likely to be required. Exceptions do exist, depending on the business in question, and thorough research is always required before committing to be spoke or off-the-shelf solutions.

Some business applications are interactive, i.e., they have a graphical user interface or user interface and users can query/modify/input data and view results instantaneously. They can also run reports instantaneously. Some business applications run in batch mode: they are set up to run based on a predetermined event/time and a business user does not need to initiate them or monitor them. Some business applications are built in-house and some are bought from vendors (off the shelf software products). These business applications are installed on either desktops or big servers. Many kinds of users are found within the business environment, and can be categorized by using a small, medium and large matrix: Wikipedia, the free encyclopedia, 2017 stated as follows:

- The small business market generally consists of home accounting software, and office suites such as OpenOffice.org or Microsoft Office.

- The medium size, or small and medium-sized enterprise (SME), has a broader range of software applications, ranging from accounting, groupware, customer relationship management, human resource management systems, outsourcing relationship management, loan origination software, shopping cart software, field service software, and other productivity enhancing applications.

- The last segment covers enterprise level software applications, such as those in the fields of enterprise resource planning, enterprise content management $(\mathrm{ECM})$, business process management (BPM) and product lifecycle management. These applications are extensive in scope, and often come with modules that either add native functions, or incorporate the functionality of third-party computer programs.

They are to be studied and applied in the daily job's executions for better productivity and performances. The importance of computer in business lays in the roles it plays in speed up the business processes and systems with top quality. Today's world computer is important to use to start any online and offline business. A computer is important to use in business to automate the manufacturing, marketing and, distribution process among others. Business software or a business application is any software or set of computer programs used by business users to perform various business functions. These business applications are used to increase productivity, to measure productivity and to perform other business functions accurately.

In organization, computers allow the application of different types of software that can help businesses keep track of their files, documents, schedules and deadlines. Computers also allow businesses to organize all of their information in a very accessible manner.

A broad term for a commercial entity involved in the computer industry. Examples of computer businesses include hardware and software manufacturers and retailers, software developers, PC repair and service companies, computer training, firms, computer networking businesses, computer consultants and more.

Computers have both advantages and disadvantages. On one hand, they allow us to access the wealth of information that is available on the internet. They also allow us to analyze massive amounts of data very quickly, saving both time and money.

\section{Importance of computers in the general business world}

The world is in an age of booming technology, running a business without computers is breathing without lungs. Take it or leave it, technology has become an integral part of the way business is done. Even when performing business services or providing products which are not technology related, to be getting your raw materials, computer network is need to place orders. Today we have mega shops dealing virtually I all materials. Such businesses like; dry cleaning, hairstyling, multiple article retail, 
wholesale, distribution shops and among others, one may find that without a computer, it's difficult to place orders with suppliers or pass information to target market dealers or customers.

\section{Inventory management}

Inventory Management Retail and wholesale business have increasingly come to rely on computers' advanced ability to keep track of inventory and assist in ordering more when stocks get low. In fact, one of the central approaches to the success of retail giant like WalMart, shoprite just to mention two, was real time ordering in which WalMart's computer systems place orders for goods as they are needed. This allowed them not to carry too much or too little of any particular item as well as to save on the manpower required to manage much of the supply chain. However, businesses of all sizes use inventory management and point of sales systems to do smaller scale versions of the same thing. Presentations and Documents While it's still possible to find a typewriter at a garage sale, the days of typed papers and documents are dead and gone.

\section{Word processing}

Word processing is a must in today's business environment. Not only are computers the medium for document creation, but the ability to email and share documents electronically has become central to the editing, approval and delivery process. Similarly, presentations and reports are commonly delivered in electronic slide show presentations or via webinars. Creators must use programs, such as PowerPoint, to create them as this is the standard for modern business.

\section{Electronic communications}

Electronic Communications has become information channels of feedback mode. A business not involved in electronic communications like use of email shall be in obsolete corner now. E-mail is one of the largest communication channels today. Customers, clients, vendors and business partners use email to make contact and transact business. Some companies go beyond email and actually encourage the use of in-house instant messaging as a method of communications between employees and departments.

\section{Internet accessibility}

Access to Internet is a business' communications lifeline. Internet-enabled computing to allows one to receive orders from customers, place orders with suppliers, research businesses, explore business ideas, communicate with government agencies and even manage your business' banking. In addition, online presence with at least a website is critical to legitimizing a business. Many companies go further and participate in social networking sites for marketing and branding purposes. Multi-site Networks If a business has more than one site or branch, then multi-site networking provides tremendous benefits for accounting, standardizing and managing your multi-faceted operation. Many companies use point of sale systems to ensure standardized operations within a chain of stores or sites. Companies that sell similar products or services in multiple locations find that computer systems help them keep track of revenues, costs and their supply chain from a central office. This allows a centralized management team to get reports on any or all sites and get a macro-view of the business when needed.

\section{Why computer-based training (CBT) in organization}

The general view is that computer-based training allows trainees to work at their own learning pace and style, both of which can be adjusted to match the individual needs of each trainee. Computer-based training is non-threatening and non-judgmental while providing immediate feedback as the training progresses.

This is a skill needed in almost every workplace. Education and the necessary experience are important for any successful career. But gaining computer skills, on the other hand, will help improve overall knowledge and understanding of the tasks, job performances and total productivity. 
DOI: $10.21522 /$ TIJAR.2014.06.01.Art004

ISSN: $2520-3088$

\section{Computer-based training (CBT)}

CBT is any course of instruction whose primary means of delivery is a computer. A CBT course is also sometimes called courseware. It may be delivered via a software product installed on a single computer, through a corporate or educational intranet, or over the Internet as Web-based training.

\section{Computer-based learning (CBL)}

Computer-based learning (CBL) is the term used for any kind of learning with the help of computers. Computer-based learning makes use of the interactive elements of the computer applications and software and the ability to present any type of media to the users. Computer skills are essential in order to utilize computers and related technology efficiently. After you've mastered the basics, this course will help one learn about Internet and email, computers, word processing, multimedia, and spreadsheets. The most common software currently being used for office work is word processing software like Microsoft Word, spreadsheet software like Microsoft Excel, and presentation software like Microsoft PowerPoint. It's important to refresh your skills with these basic programs.

\section{The importance of computer training in the workplace}

According to Milton Kazmeyer (2007) a writer and an expertise in computers, astronomy, alternative energy sources and the Environment, in the modern workplace, computer skills are an incredibly valuable addition to any employee's personal portfolio. As a worker, developing and cultivating computer skills can greatly increase your desirability to employers, and it can allow you to take on roles you might not have previously considered. As an employer, training your employees in computer skills can not only increase productivity but also help you stave off problems that can cost time and significant amounts of money to fix. Explaining further, the following salient points was added on why workforce must be trained in computer usage.

\section{Computer skills}

These days, it is hard to find a job that does not involve a computer in some way. PCs are ubiquitous in any office environment, and even blue-collar workers may enter data into terminals or use portable devices to look up information on the job. Even the most basic retail cashier positions often involve the use of a computerized point-of-sale system. Familiarity and experience with computers can benefit almost any type of worker.

\section{Training and experience}

Training in basic computer skills can greatly affect how quickly a new hire picks up the specific applications unique to your business. To someone without computer experience, a PC can be an unnerving, unfamiliar piece of hardware, and the constant fear of causing some catastrophic error can make it difficult to feel at home at the keyboard. Training new employees in computer skills will ensure that everyone has the basic knowledge they need to function at your business, and it can help new-hires with computer skills gain familiarity with your specific business systems.

\section{Productivity}

Studies have shown that computers increase productivity, but those gains can only be realized if employees are comfortable and experienced with the systems. According to the Information Technology and Innovation Foundation, investments in technology produce gains in productivity three to five times greater than other investments by allowing employees better access to the information they need to do their jobs. Ensuring that your employees are trained and familiar with computers will help them spend less time tracking down that information and more time utilizing it to perform vital tasks for your company.

\section{Computer safety}

Giving your employees some basic computer knowledge can also help you head off problems. Malware programs and hackers often rely on user error or ignorance of common traps to gain access to a system, and training your employees in how to avoid these mistakes can greatly enhance your 
business's online security. A simple training course in how to spot phishing attempts, in which a user or Web site employs deception to extract data from unwitting employees, may mean the difference between keeping your company's network secure and losing vital data to an outsider.

The advent of computers has revolutionized the workplace and redefined operational practices. The use and deployment of computers, computer systems and information technology (IT) applications in every aspect of business is now commonplace. The recent application and adoption of Web-based, information and telecommunication technologies have force-multiplied the capabilities and benefits of computers. The importance of computers in business cannot be overstated.

Businesses are using Internet communication technologies, networking and relevant software to enable workers and professionals to collaborate and work across locations and geographical boundaries and streamline work-flow management.

Computer systems connected over a Web-based environment or an intranet-based network can communicate with each other. Varied connectivity and access technologies with computing interfaces facilitate communication of employees with business partners, suppliers, customers, government regulators and other stakeholders.

Deployment of Enterprise Resource Planning (ERP) software solutions, Management Information Systems (MIS), other information management and business intelligence technologies help businesses to centralize core business activities and operations, manage gigabytes of generated information and aid decision-making processes.

Software, productivity tools and networking applications installed in computers, laptops and workstations enable employees in a business to streamline their work-flows, execute assigned tasks faster and aim to achieve organizational goals and targets.

All businesses investing in computers and IT systems look to leverage the Return on Investment (ROI) parameter. Long-term planning and allocation of resources for IT are helping organizations to take up ambitious business expansion activities, channelize workforce productivity, adjust strategic goals and thereby positively impact the bottom line.

The employees cannot achieve these business operations in the workplace without the knowledge of computer and to apply it in their day to day job functions if they are not trained on the use of computer. Poor knowledge of computer has rendered public service work useless.

\section{Advantages of being computer literate in the workforce}

In the words of Bill Gates, founder of Microsoft, the internet is becoming the town square for the global village of tomorrow. We live in a world filled with technology. Just ten years ago, we didn't encounter as many computers as we now do. The reality is that we can't afford to be technophobes anymore. Computer literacy is not just a skill that's reserved for the elite set. It is time to embrace the technological revolution and equip ourselves for a bigger and brighter future. Bill gates said that: Just in case you've been living under a rock, the World Wide Web (WWW) has been alive and kicking for the last 25 years. The origin of the internet takes us back 45 years or so. This is the time of the digital and computer revolution.

With the help of the internet, we get to connect and communicate with people across the world. The internet has made it easy for people of different backgrounds to come together for business and social purposes in a way we would have never anticipated before. What has this got to do with computer literacy? Everything!

Basic computer knowledge allows us to 'browse' or 'surf the internet'. However, that is not all. With computer literacy and the internet, we have greater access to:

- Information and knowledge

- A greater understanding of culture and people of diverse backgrounds

- More information on emerging trends

- Greater connection to people from around the world on a social and business level.

For the past decades, the business operations are not possible without computers, and computers are a product of business. Computer technology is very important especially in the business field. It can help to make work easier. Computer is a powerful tool, allowing you easily extract data in order to 
DOI: $10.21522 /$ TIJAR.2014.06.01.Art004

ISSN: $2520-3088$

prepare reports and analyze the information. Computers can help a business stay in contact with its customers as well.

Computers can help managers keep track of the financial status of the company on a yearly, monthly or even day-to-day basis. Companies can use their computers to print checks for payroll and expenditures, and can form a direct link to the company's bank account. Computers through internet connection made business transactions easier and more convenient. As compared to hard copied data which is more prone to damage data saved in the computer is more secured. Thus, computer plays a big role and importance in the business field.

According to Pallab Dutta (2017), the advent of computers has revolutionized the workplace and redefined operational practices. The use and deployment of computers, computer systems and information technology (IT) applications in every aspect of business is now commonplace. The recent application and adoption of Web-based, information and telecommunication technologies have forcemultiplied the capabilities and benefits of computers. The importance of computers in business cannot be overstated.

Businesses are using Internet communication technologies, networking and relevant software to enable workers and professionals to collaborate and work across locations and geographical boundaries and streamline work-flow management.

Computer systems connected over a Web-based environment or an intranet-based network can communicate with each other. Varied connectivity and access technologies with computing interfaces facilitate communication of employees with business partners, suppliers, customers, government regulators and other stakeholders.

Deployment of Enterprise Resource Planning (ERP) software solutions, Management Information Systems (MIS), other information management and business intelligence technologies help businesses to centralize core business activities and operations, manage gigabytes of generated information and aid decision-making processes.

Software, productivity tools and networking applications installed in computers, laptops and workstations enable employees in a business to streamline their work-flows, execute assigned tasks faster and aim to achieve organizational goals and targets.

All businesses investing in computers and IT systems look to leverage the Return on Investment (ROI) parameter. Long-term planning and allocation of resources for IT are helping organizations to take up ambitious business expansion activities, channelize workforce productivity, adjust strategic goals and thereby positively impact the bottom line.

All these assertions point out that employees have to excel in the use of computer to work in their respective schedules of duties. Therefore, they have to be trained and be informed on the computer application technology in order to perform in boosting productivity.

\section{Why is it important to be computer literate in modern times?}

By the words of Bill Gates, the founder of Microsoft, the following salient points are also noted and identified in our world today business operations corning the computer knowledge: 


\section{Why Learn to Use a Computer?}

- To open up a world of information

- To easily access government \& other organizations

- To connect with family \& friends

- To have fun!

\section{This is the age of the personal computer revolution}

In answer to the why learn to use of computer, Bill gates said: "I think it's fair to say that personal computers have become the most empowering tool we've ever created. They're tools of communication, they're tools of creativity, and they can be shaped by their user."- Bill Gates

There is a new language emerging. Words such as coding, HTML and web design may have us approaching this world with a mixture of dread and fascination. The reality is that the children we bring into the world today will be the digital natives and influencers of tomorrow.

\section{The advantages of computer literacy}

In light of the above the following nine (9) reasons of being company literate in the workforce was identified.

\section{Computer literacy addresses the gap in your knowledge}

If you are a professional in your 30's or 40's doing the same thing on a daily basis, you probably know that you need a little technological push in the right direction to reach your full potential. Many people unwittingly settle in their careers for fewer chances and opportunities because they feel as if, 'you can't teach an old dog new tricks'

What a sad loss of rich intellectual heritage and experience!

With a little training in basic computer skills you could be flying in your career! Digital skills training has a way of opening doors and directing dreams. You can easily sign up and study part-time so that you can bridge the gap in your understanding.

The world is moving toward digital education faster than the blink of an eye. If you want to get ahead it pays to adopt the mind-set of the new digital natives.

\section{Computer Literacy supports Entrepreneurship}

With a whole new world that is literally at your fingertips, doesn't the prospect of your own development get your pulses racing? Being computer literate will open your world up to new ideas, enable your self-confidence and help you to innovate. Just imagine all you need is an internet connection, a PC or laptop and a little bit of business sense and you could be streets ahead. Now more than ever tech skills for entrepreneurs are of great importance. 
DOI: $10.21522 /$ TIJAR.2014.06.01.Art004

ISSN: $2520-3088$

\section{Depolarization of the office space - a new and real phenomenon}

With the increased digitization of the world and the processes that we engage in, even our offices have become virtual/digital spaces. Depending on your industry and if you have the option to do so, you could easily work from home, a holiday destination, the beach or anywhere else that you choose.

\section{Computer literacy skills command innovation}

As you get savvier with your computer skills, you will be inspired to innovate, experiment, try new things and get ahead in your industry with the New apps, new coding programs, blogging, you name it. The digital world is yours for the taking and working with.

\section{The importance of computer literacy in education}

There are different markers of development along the education journey. Assuming a child receives early exposure to computer skills training, one of the end-goals as that child matures is to be computer literate.

\section{Helps students to navigate digital learning platforms}

Students stand to benefit from their early computer literacy skills training as it will help them to navigate digital learning platforms. Many colleges and institutions of higher learning make use of elearning courses. At this phase computer literacy helps immensely in allowing the student to navigate the technology needed to engage with online learning platforms.

\section{Enhances job opportunities}

Before a student enters the working world, it is imperative that they receive some kind of computer skills training. Computer literacy prepares students for the norms and algorithms of the business world. Having some level of computer literacy enhances job opportunities. You can easily study a Short Programme in Fundamentals of Microsoft Office to help you on your way.

\section{Communication}

It goes without saying that the business world involves a great deal of communication. This is both interpersonally and electronically. Think emails, presentations, workshops, Skype calls and so on. There is always a level of computer literacy involved.

\section{Computers streamline business processes}

Previously, business processes used to be very tedious. Before we really, truly embraced computer skills one might have sent a staff member around the office to get people to sign a memo. Nowadays an email or giving somebody your banking details in which to deposit funds is just as good as being there or sending somebody to the bank.

Embrace the fact, computers are here to stay! Instead of computers being the kind of equipment that stands between us and our personal success, we should embrace the convenience and the revolution that they bring to our worlds. Computer literacy is the new currency that will help pave your path to your career and personal development. Therefore, it is time to bring you up-to-date in computer technology application appliance in business and individual life.

\section{Research methodology}

The statistical methods used in this study are obtained by survey and questionnaires. Due to the advantages presented by the data analysis, these approaches are adopted to analyze the statistical data by the survey method was used for data. The information related to technology and workers' productivity was collected through interviews and survey. These interviews were carried out based on the personal opinions of high rank heads of Department MDAs/ agencies and questionnaires with statistical data analysis. The survey included 50 from 200 employees working in different Nigerian ministries and agencies sampled randomly. While the real return of questionnaires form was 37 from 50 applications were applied on employees in this survey. 
The attitudinal questions attempted to reveal the viewpoints, opinions, and the perceptions of the interviewees with respect to the different dimensions and variables of the technology, communication, training, and productivity by using the Likert scale has been utilized to measure the study sample. In order to derive a usable questionnaire for this research, many standard questionnaires regarding technology, performance and productivity were investigated.

Furthermore, the reliability of the questionnaire in these studies has been assessed by Cronbach's alpha as percent (0.946), which is an appropriate criterion for evaluating the reliability of the measurement tools. Through a pre-test done by using the IDM / SPSS package and Cronbach test.

Table 1 and 2 below illustrates how the total reliability of the questionnaire was determined

Table 1. Case processing summary

\begin{tabular}{|l|l|l|}
\hline & Number & $\mathbf{\%}$ \\
\hline Valid & 37 & 100 \\
\hline Excluded & 0 & 0 \\
\hline Total & 37 & 100 \\
\hline
\end{tabular}

Cases

Table 2. Reliability statistics

\begin{tabular}{|l|l|}
\hline $\begin{array}{l}\text { Cronbach's } \\
\text { Alpha }\end{array}$ & $\begin{array}{l}\text { No. of } \\
\text { Items }\end{array}$ \\
\hline 0.946 & 35 \\
\hline
\end{tabular}

Note $=35$

$=0.946$

\section{Discussion of tables, data analysis and results of findings}

This study examined the relationship between technology and workers 'performances and productivity in Nigeria ministry and agency. The empirical data collected is based on the perceptions and opinions of civil service employees. Data analysis was used to test via a statistical program which is SPSS. Results of this case study of Ministries and Agencies workers in Nigeria indicated that a positive relationship exists between technology, performances and productivity.

\section{Technology, performances and productivity}

The analysis provided strong supporting for the relevance of the technology on productivity / performances. Moreover, there is a correlative relationship between technological changes in productivity and performances of the individual. The more of administration and policy makers is interested in keeping up with the modern and advanced technological changes to production of goods and services, the more to achieve more in productivity and performances of workers. The findings of this study indicated that the perceived usefulness of technology has a significantly positive influence on employee's productivity and performances.

In summary, results of the data analysis for our research are as shown below Tables. As a result, in this section, it can be shown the correlation between technology and individual's productivity and performances in terms of the percent of workers answers is around 90\% which says their ministry or agency encouragement of employees training is important to make modern use of technology to boost productivity and performances in service delivery. 
DOI: $10.21522 /$ TIJAR.2014.06.01.Art004

ISSN: $2520-3088$

Valid

Table 2. Management recognizes the importance of technology in the productivity and performance

\begin{tabular}{|l|l|l|l|l|}
\hline $\begin{array}{l}\text { Degree of } \\
\text { Opinion }\end{array}$ & Frequency & Percent & Valid Percent & Cumulative Percent \\
\hline Disagree & 2 & 5.4 & 5.4 & 5.4 \\
\hline Neutral & 2 & 5.4 & 5.4 & 10.8 \\
\hline Agree & 21 & 56.8 & 56.8 & 67.6 \\
\hline $\begin{array}{l}\text { Strongly } \\
\text { Agree }\end{array}$ & 12 & 32.4 & 32.4 & 100.0 \\
\hline Total & 37 & 100.0 & 100.0 & \\
\hline
\end{tabular}

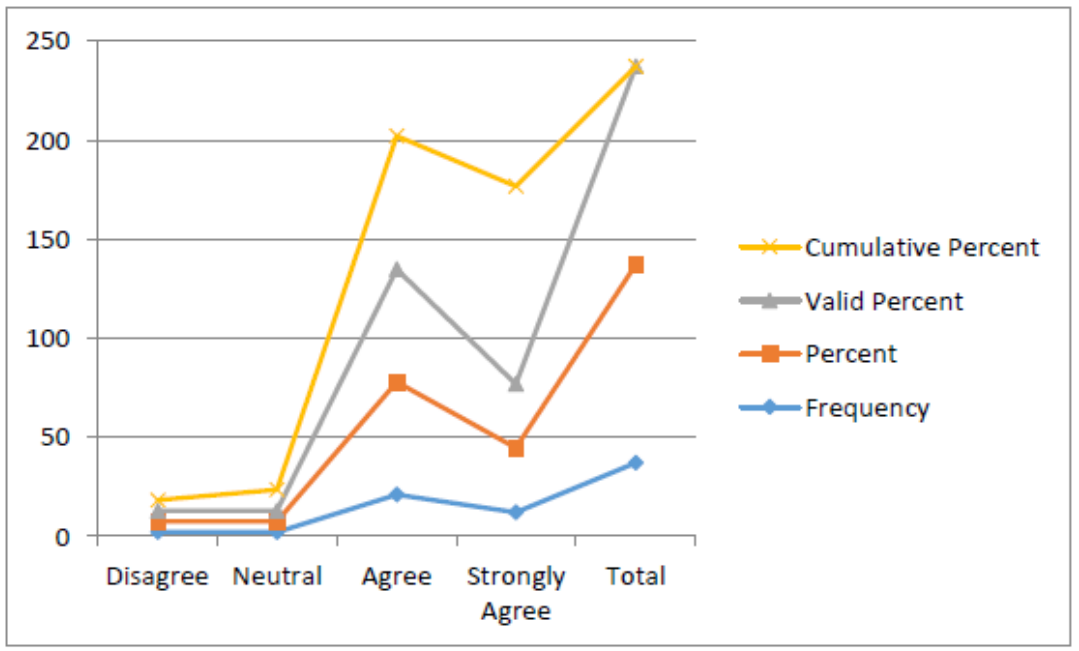

\section{Collecting information}

The workers' outcome management based to retain all data and information about customers by technological services. It has reduced by the employee's survey that the prevalent situation in the ministries and agencies which most of its workers are affected by technology and help them to increased performance. Therefore, the ministry / agency might keep whole documents about customers, $72.2 \%$ from employees have extremely strongly agreed about their ministry / agency should keep all documents for customers in computerized system. It leads to giving an extremely positive impact on the ministries/ agencies and its customers as it shows in Table $\mathbf{3}$ below.

Valid

Table 3. The ministry / agency management based to retain all data and information about Customer by Technological Service (computerize system)

\begin{tabular}{|l|l|l|l|l|}
\hline Degree of Opinion & Frequency & Percent & Valid Percent & Cumulative Percent \\
\hline Disagree & 2 & 5.4 & 5.4 & 5.4 \\
\hline Neutral & 2 & 5.4 & 5.4 & 10.8 \\
\hline Agree & 21 & 56.8 & 56.8 & 67.6 \\
\hline Strongly Agree & 12 & 32.4 & 32.4 & 100.0 \\
\hline Total & 37 & 100.0 & 100.0 & \\
\hline
\end{tabular}

\section{Internet and marketing}

The ministry / agency management has not much adopted the use of the internet in the service delivery processes of the products and services to reduce production costs and increase customer satisfaction. This indicates a lack of optimal using of technology. While the existing old technology: customer archive and a computerization system in the ministry / agency are obsolete. The overall of 
this variable have negative impact on productivity and performance. This shows that technology is not applied in the best and up to date way. This is evident from the responses of the respondents, where the percentage of use of technology in the public office for the Internet was about $48.6 \%$. This effect is not positive for management, taking into account that the presence of technology, its uses in goods and services, delivery and production processes through the internet which is clearer and faster in modern services of customers.

This is shown in Table 4 below.

\section{Valid}

Table 4. The ministry / agency management adopted the use of the Internet in the service delivery processes of the services to reduce production costs and increase customer satisfaction

\begin{tabular}{|l|l|l|l|l|}
\hline Degree of Opinion & Frequency & Percent & Valid Percent & Cumulative Percent \\
\hline Strongly Disagree & 3 & 8.1 & 8.1 & 8.1 \\
\hline Disagree & 9 & 24.3 & 24.3 & 32.4 \\
\hline Neutral & 7 & 18.9 & 18.9 & 51.4 \\
\hline Agree & 10 & 27.0 & 27.0 & 78.4 \\
\hline Strongly Agree & 8 & 21.6 & 21.6 & 100.0 \\
\hline Total & 37 & 100.0 & 100.0 & \\
\hline
\end{tabular}

The table was further put to Line graph to show levels in percentage.

\section{Below is the line graph}

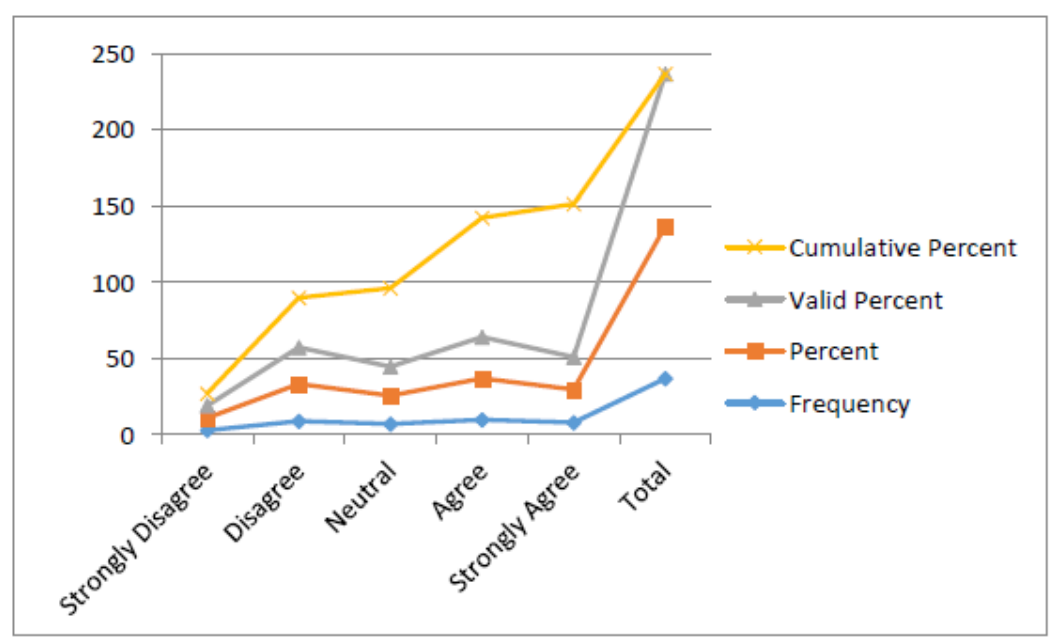

\section{Employees training}

This final section presents the statistics analysis of workers training on use of modern technology by developing a time schedule to improve performances and production. It can be noted that the percent of research sample was $29.7 \%$ as demonstrate Table 5, who wish the management does not base to work on employees training. In other words, the workers do not get on the job computer training. On the words, the workers 'do not get on perfectly skills schedule processing on modern technology in the ministry or agency as required and discussed above. It therefore stands to conclude that there appears a substantially large impact of training on productivity. The achievement and performances of workforce is poor and ends in obscurity generally. 
DOI: 10.21522/TIJAR.2014.06.01.Art004

ISSN: $2520-3088$

\section{Valid}

The Ministry / Agency management sees to the training of employees in us ing modern technology by developing a time schedule to improve production.

Table 5. Data Analysis

\begin{tabular}{|l|l|l|l|l|}
\hline Degree of Opinion & Frequency & Percent & $\begin{array}{l}\text { Valid } \\
\text { Percent }\end{array}$ & Cumulative Percent \\
\hline Strongly Disagree & 11 & 29.7 & 29.7 & 29.7 \\
\hline Disagree & 9 & 24.3 & 24.3 & 54.1 \\
\hline Neutral & 6 & 16.2 & 16.2 & 70.3 \\
\hline Agree & 10 & 27.0 & 27.0 & 97.3 \\
\hline Strongly Agree & 1 & 2.7 & 2.7 & 100.0 \\
\hline Total & 37 & 100.0 & 100.0 & \\
\hline
\end{tabular}

\section{Graph representation with line graph}

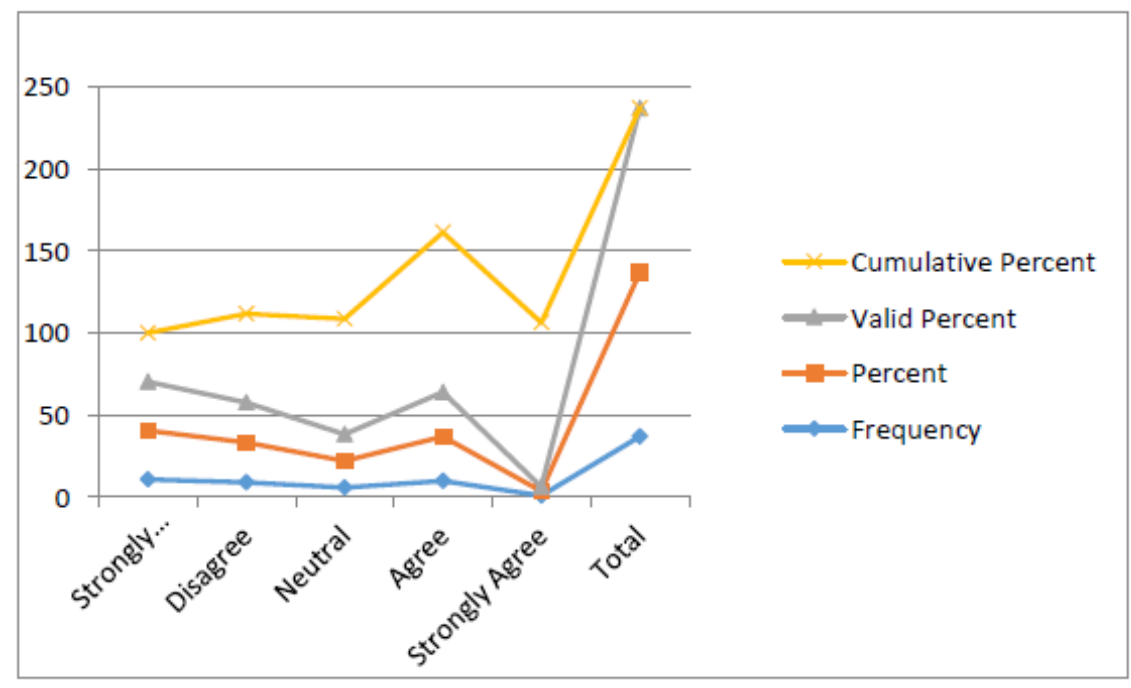

\section{Conclusion and recommendations}

It is important to understanding that the use technologies are basic in organizations for effective and efficient performances. In terms of operations and distributions in global productivity, the viable efficient goods and services delivery cannot be covered without computer. It boosts productivity, efficiency and increases performances. One can see the difference from the kinds of technologies used in the service delivery by or across the developed world.

Technological inventions should be used altogether for different purposes and workers should be trained to use them accordingly. To seek how productivity can be improved with the use of technologies one has to apply a holistic view to unify all variables specifically, such as communication, the internet, and training.

The study among others have illustrated that the bulk of the evidence from this study is that technology does have ability to improve and develop of individuals skills. It also significantly impacts on productivity and performances of organizations generally.

Furthermore, it can be concluded that the impact of technologies on workers' productivity and performance is not limited but large with a lot of goodies.

In most cases, employees don't have high skills in use technology due to they have lacked good training.

Additionally, when the employee doesn't have good skills due to lack of perfect training that is considered a big element which have negative effect on productivity and performances in the workplace. 
To increase productivity and performances, the administration and policy makers should have up-todate internal communication guidelines and organize pieces of training and other support for employees, particularly when there is advanced new technology.

The study has suggested that organizing training for the employees or workforce basic knowledge will go a long way to develop them, improve and increase productivity as well as gear up their performances in today's service delivery and economy development.

\section{References}

[1]. Andriessen, Daniel (2004). "Reconciling the rigor-relevance dilemma in intellectual capital research". The Learning Organization. 11 (4/5): 393-401. doi:10.1108/09696470410538288.

[2]. Alavi, Maryam; Leidner, Dorothy E. (2001). "Review: Knowledge Management and Knowledge Management Systems: Conceptual Foundations and Research Issues". MIS Quarterly. 25 (1): 107-136. doi:10.2307/3250961. JSTOR 3250961.

[3]. Bontis, Nick; Choo, Chun Wei (2002). The Strategic Management of Intellectual Capital and Organizational Knowledge. New York: Oxford University Press. ISBN 0-19-513866-X.

[4]. Colombo E, Stanca L (2008)The Impact of Training on Productivity: Evidence from a Large Panel of Firms 35: $1140-1150$.

[5]. Doroshev VG (1988) Physiological regulation at the workplace. Nauka Press, Leningrad.

[6]. Ferguson, J. (2005). "Bridging the gap between research and practice". Knowledge Management for Development Journal. 1 (3): 46-54.

[7]. Gavrilov EV, Dmitrichenko MF, Dolya VK (2008) Systemology in transport. Ergonomics. Znannya Press, Kiev.

[8]. Groth, Kristina. "Using social networks for knowledge management" (PDF). Royal Institute of Technology, Stockholm, Sweden. Retrieved 18 April 2013.

[9]. Hayes, M.; Walsham, G. (2003). "Knowledge sharing and ICTs: A relational perspective". In EasterbySmith, M.; Lyles, M.A. The Blackwell Handbook of Organizational Learning and Knowledge Management. Malden, MA: Blackwell. pp. 54-77. ISBN 978-0-631-22672-7.

[10]. John V, Reenen RS (2005) information technology and productivity. It ain't what you do it's the way that you do I.T.

[11]. Konings J Vanormelingen S (2010) The impact of training on productivity and wages: firm level evidence, IZA Discussion Papers, No. 4731.

[12]. Kristen P, Lee R. Pew Research Center (December 2014) Technology's Impact on Workers.

[13]. Kimmo P (2012) The impact of communication technologies on individual workers' productivity. $\mathrm{k} 77303$.

[14]. Konings J, Vanormelingen S (2009) The Impact of training on productivity and wages: Firm Level Evidence, Discussion. Paper No. 244.

[15]. Mark D, Timothy D, Kenneth T (1997) Workers, wages, and technology. Q J Econ 112: 253-290.

[16]. Milton Kazmeyer (2007). Expert Computers, Astronomy, Alternative Energy sources and the Environment.

[17]. Mariposa Leadership; Technology -- Is It Helping Communication in Your Workplace?; Aug 02, 2007

[18]. Maier, R. (2007). Knowledge Management Systems: Information and Communication Technologies for Knowledge Management (3rd edition). Berlin: Springer.

[19]. Nanjappa, Aloka; Grant, Michael M. (2003). "Constructing on constructivism: The role of technology" (PDF). Electronic Journal for the Integration of Technology in Education. 2 (1). Archived from the original (PDF) on 2008-12-17.

[20]. Nonaka, Ikujiro; Takeuchi, Hirotaka (1995). The knowledge creating company: how Japanese companies create the dynamics of innovation. New York: Oxford University Press. p. 284. ISBN 978-0-19-509269-1.

[21]. Nonaka, I.; von Krogh, G. \& Voelpel S. (2006). "Organizational knowledge creation theory: Evolutionary paths and future advances" (PDF). Organization Studies. 27 (8): 1179-1208. doi:10.1177/0170840606066312.

[22]. Nottingham Trent University; A Study of the Impact of Information Technology on Business; Julie Eatock et al.

[23]. BusinessWings.co.uk; The Importance of Backing up Data Files; Vickie Lamb.

[24]. Small Business Bible: Some Advantages and Disadvantages of Information Technology.

[25]. Rohan S, Madhumita M (2012) Impact of Training Practices on Employee Productivity: A Comparative Study 2: 87-92. 
DOI: $10.21522 /$ TIJAR.2014.06.01.Art004

ISSN: $2520-3088$

[26]. "Rhetorical Structure Theory Website". RST. Retrieved 19 April 2013.

[27]. Snowden, Dave (2002). "Complex Acts of Knowing - Paradox and Descriptive Self Awareness". Journal of Knowledge Management, Special Issue. 6 (2): 100-111. doi:10.1108/13673270210424639.

[28]. Sepulveda F (2005) Training and Productivity: Evidence for US Manufacturing Industries. Oxf Econ 62: 504-528.

[29]. Serenko, Alexander; Bontis, Nick (2004). "Meta-review of knowledge management and intellectual capital literature: citation impact and research productivity rankings" (PDF). Knowledge and Process Management. 11 (3): 185-198. doi:10.1002/kpm.203. Archived from the original (PDF) on 2007-09-26.

[30]. Wyssusek, Boris. "Knowledge Management - A Sociopragmatic Approach (2001)". CiteSeerX. Retrieved 18 April 2013.

[31]. U.N. Food and Agriculture Organization: Computers as Management Tools. 


\title{
Strategic Management and Corporate Planning, Tools to Achieving Organizational Products Continuous Efficiency: The Case of Multi- National Company's Products in Nigeria
}

\author{
Article by Osogu Fred Obioma \\ Ph.D. Programme in Management, Texila American University, Guyana \\ E-mail:fredobioma@yahoo.com
}

\begin{abstract}
The desk review of literatures in strategic management and corporate planning as tools in organizations strategic operational framework shows excellent prospects in management of corporate establishments.

World-wide, products like Coca-Cola soft-drink and Maggi cubes for cooking, have been household consumer goods. Their availability at all times is attributed to Strategic Management and Corporate Planning techniques adopted in creating the brands. It is being observed that these products had foreign origins with good leadership lifestyle. In Nigeria for instant, they were incorporated over 50years ago as Multi-National Companies (MNCs). This study reveals that the applications of strategic management and corporate planning are indispensable management tools that gave leverage to prosper growth and maintain high market shares.

The study key findings show that availability of aforementioned products' success story factors come from the combination of strategic corporate planning of people, process, marketing and leadership style. The study made some policy recommendations that: There is strong need for manufacturing organizations operating in a dynamic environment wrapped with economic uncertainty to embark on realistic and systematic implementation of strategic management and corporate planning principles to overcome challenges. For business development, market leadership and desires for perpetual effectiveness, there is strong need of good strategic management and corporate planning as tools to enhance business prospects. The application of strategic management and corporate planning is desirable for organizations to continue being in operations no-matter the economic business trends.
\end{abstract}

Keywords: Strategic Management, Corporate Planning Decision-making, Continuous Organization, Efficiency, Growth, and Products.

\section{Introduction}

It is widely acknowledged that most incorporated or registered business organizations should operate in perpetuity. This portend that the big or small business organizations are not supposed to wound-up with their founders. The success story factors of most of the blue chips called Multi-National Companies (MNC) incorporated more than fifty years ago are operating in full capacity, producing viable goods and services, also doing social corporate responsibilities work in operating environments. This long existence is mainly attributed to good governance imbedded in strategic and corporate planning management style in leadership.

The literature review of MNC) operations shows the success existence is use strategic management and corporate planning, as tools in achieving efficiency. Products continuous existences, successful performance and growth are based on strategic management and corporate planning tools tactically applied to get desired results. Through strategic management business processes, planning and decisionmaking are constantly tweaked to suit the current economic realities of the day.

The study shows that for organizations to remain afloat in the face of business uncertainty, and unpredictable government policies strategic and corporate planning management is eminent to sustain production. The competitive business environment and declining consumers demand is overcome by application of strategic management and corporate planning as management tools for survival in times of business uncertainty. 
The objective of this paper is therefore, to analyze beyond theoretical activism, the operational efficiency that can be gained by manufacturing organization that has consistently adopted strategic and corporate planning management in their operations. The leadership lifestyles of MNC with strategic and corporate planning management tools to attain high level of sustainable growth and profitability for production of Coca-Cola soft-drink, Maggi cubes, beverage tea drinks Ovaltine and Milo has played vital roles. The products have been household consumer goods available world-wide. This multinational's organization has witnessed many phases of global economic melt-down, yet they are effective all times. For instance, in 1986, Nigeria self-structural adjustment programmes that signaled bad economic tidings and woes to many manufacturing organizations in the country did not put them off. But they continued to navigate higher in sustainable economic development and growth. The system of management using strategic management and corporate planning as tool brought their success story factors.

In this regard, the paper is divided into five sections as follows; section 1, the introduction and back ground of the study, section 2, is the literature review. While Section 3 is devoted for the methodology, Section 4 discusses the operational strategies and corporate planning mechanism in products production. Finally, Section 5, is the conclusions, policy suggestions and recommendations for corporate manufacturing organizations techniques in and outside the country.

\section{Literature review}

The concept and relevance of strategic management and corporate planning in the business environment are important bodies of literature to be reviewed. The lessons learnt from this review will be articulated to further help appreciated the success story factors behind the operational performance of the big and small manufacturing organizations in a dynamic business environment.

According to Nag, R. et al, (2007), strategic management involves the formulation and implementation of the major goals and initiatives taken by a company's top.

Management on behalf of owners based for consideration of resources and an assessment of the internal and external environments in which the organization competes. On the other hand, strategic planning is an organization's process of defining its strategy, direction, and making decisions on allocating its resources to pursue this strategy (Nag, R.; Hambrick, D. C.; Chen, M.-J, 2007).

Bruce, Henderson (1981), further explains that Strategic planning is an organizational management activity that is used to set priorities, focus energy and resources, strengthen operations, ensure that employees and other stakeholders are working toward common goals, establish agreement around intended outcomes/results, and assess and adjust the organization's activities and policies to suit present day realties. Strategy has been practiced whenever an advantage was gained by planning the sequence and timing of the deployment of resources while simultaneously taking into account the probable capabilities and behavior of competition.

Henry Mintzberg, business management expert since (1983), gave many definitions and perspectives on strategies reflecting in both academic research and in practice. Henry Mintzberg business management analysis stated five types of strategies as follows:

- That strategy as plan - a directed course of action to achieve an intended set of goals; similar to the strategic planning concept.

- Strategy as pattern - a consistent pattern of past behavior, with a strategy realized over time rather than planned or intended. Where the realized pattern was different from the intent, he referred to the strategy as emergent.

- Strategy as position - locating brands, products, or companies within the market, based on the conceptual framework of consumers or other stakeholders; a strategy determined primarily by factors outside the firm.

- Strategy as ploy - a specific maneuver intended to outwit a competitor.

- Strategy as perspective - executing strategy based on theory of the business, natural extension of the mindset, ideological perspective of the organization.

David Besanko et al, (2012) explained that strategic management provides overall direction to the enterprise, specifying the organization's objectives, developing policies, allocating resources designed to achieve and implement plans. Academicians and practicing managers have developed numerous 
models and frameworks to assist in strategic decision making in the context of complex environments and competitive dynamics (Ghemawat, Pankaj Spring, 2002). Strategic management is dynamic in nature; the models often include a feedback loop to monitor execution and inform the next round of planning (Hill, Charles W.L., Gareth R. Jones, 2012).

Michael Porter, 1996 identifies three principles underlying strategy, viz: creating a unique and valuable market position, making trade-offs by choosing, what not to do and creating fit by aligning company activities with one another to support the chosen strategy. In this light the analysis registered MNCs wisdom to adopt and follow through these basic principles to make the said products remain efficient, effective and available without losing its market value despite the prevailing economic trends.

There are two major vital elements in strategic management which runs simultaneously to make strategies to work positively, business viable, and the products line marketable no matter the business climate. The elements are: Formulation and implementation.

\section{Formulation}

Formulation of strategy involves analyzing the environment in which the organization operates, then making a series of strategic decisions about how the organization will compete. Formulation ends with a series of goals or objectives and measures for the organization to pursue in consideration of business environment. Environmental analysis are: (a) Remote external environment involving political, economic, social, technological, legal and environmental landscape (PESTLE); (b) Industry environment, such as the competitive behavior of rival organizations, the bargaining power of buyers/customers and suppliers, threats from new entrants to the industry, and the ability of buyers to substitute products (Porter's 5 forces); and (c) Internal environment, regarding the strengths and weaknesses of the organization's resources.

Strategic decisions are based on insight from the environmental assessment and responses to strategic questions about how the organization will compete in addressing:

- What is the organization's business?

- Who is the target customer for the organization's products and services?

- Where are the customers and how do they buy? What is considered "value" to the customer?

- Which businesses, products and services should be included or excluded from the portfolio of offerings?

- What is the geographic scope of the business?

- What differentiates the company from its competitors in the eyes of customers and other stakeholders?

- Which skills and capabilities should be developed within the firm?

- What are the important opportunities and risks for the organization?

- How can the firm grow, through both its base business and new business?

- How can the firm generate more value for investors?

The answers to these and many other strategic questions result in the organization's strategy and a series of specific short-term and long-term goals or objectives and related measures. To this end, and in pursuance of the business objective to fulfill the realities of business economics changes in trends, the Multi-national companies seriously take the advantages of strategies and corporate planning in management to make their products services to be continuously viable and available despite any business or economics changes in operations.

\section{Implementation}

Implementation is the process of strategic management that involves decisions regarding how the organization's resources (people, process and IT systems) will be aligned and mobilized towards the objectives. Implementation results in how the organization's resources are structured (regarding product or service and geography). It is leadership arrangements, communication, incentives, and monitoring mechanisms to track progress towards objectives (Cameron, Bobby Thomas, 2014). It is running the day-to-day operations of the business (operations management). In specific terms, it looks into key departments or functions, such as "logistics management" or "marketing management," which take over once strategic management decisions are implemented. According to Cameron, Thomas (2014), for 
goods and services to continuously be viable and available at all time strategic and planning is very crucial and inevitable in business processes. Furthermore, strategic management and team skills development is critical to Organizational effective and efficient operational performance. Teamwork give companies a good advantage in reaching their goals and overcoming competitions. Team can be a group of people with a full set of complementary skills required to complete a task, job, or project. Team building is one of the most widely used group-development activities in organizations. Among all organizational activities, one study found team-development to have the strongest effect (versus financial measures) for improving organizational performance (Marquardt, Michael J., 2011). A good team is one which has a common vision. According to them, A team is a group of individuals, all working together for a common purpose. Teams work in an organization to improve quality, complete projects and change processes. A team must have some components to ensure the success of the organization. A variety of skills and personalities can also help a team excel.

Marquardt, Michael J. (2011), also outlined the characteristics of a good team as where: (a) everyone participates actively and positively in meetings and projects. (b) Team goals are understood by everyone; (c) Individual members have works together to solve the problem; (d) Members are carefully listened to and receive thoughtful feedback; (e) Team members should have a clear understanding of the team's goals and objectives; (f) effective and open communication is also crucial to a team's success; and (g) Have listening skills.

Team building is a collective term for various types of activities used to enhance social relations and define roles within teams, often involving collaborative tasks. It is distinct from team training, which is designed to improve the efficiency, rather than interpersonal relations. When team collaboration succeeds at high levels, projects and businesses thrive well.

Explaining further the concept of effective strategic management and corporate planning, Brian Hill (2013) says that corporate planning is a process used by businesses to map out a course of action that will result in revenue growth and increased profits. Although large corporations may have staff members -- or entire departments -- devoted to performing the planning function, small business owners can become proficient through learning basic concepts and putting forth the effort necessary to create a comprehensive plan (Brian Hill, 2013). The strategic management component of business planning defines strategies as business tools use to meet its goals and missions.

Business planning provides details on the business' operations, products and services, and marketing strategies as it relates to the inclusive industry.

This process expounds the operation strategies from short- and long-term views while focusing on the overall activity of the company. The business plan does not identify specific employee strategies but rather provides industry strategies.

On other hand, corporate planning is defined as the strategies that the employees will take to meet the business' goals and missions (Kemp, Roger L; c 2008). This type of planning like strategic planning focuses on staff responsibilities and procedures. According to Kemp, Roger L. (2008), as with business planning, strategic planning requires a close look at the company's missions, strengths and weaknesses. However, corporate planning identifies the step-by-step process of the business, such as the actual steps the staff will take to counteract challenges, training employees to achieve accomplishments. Corporate planning also provides specific, measurable goals with realistic time lines.

Strategic management and corporate planning are tool that helps organization determine when new directions and changes are needed. It reviews results for recognition of potential issues for the company to quickly adapt to customer demand and needs. Business and strategic plans should be reviewed periodically. The plans should be reviewed to compare the business' current stand points against those that were outlined in the plans. Adjustments should be made, where necessary, to align the business' actual activities to the defined plans. When analyzing needed changes, consideration should be given to the industry's environment and trends, also the economy's stability, customer demand and business needs. The balancing of the business and strategic plans should outline the moves or changes that the business will strive to implement and framework the strategies that the employees will use to meet the business' missions and goals. Corporate strategy identifies barriers to achieving company objectives and develops an approach that allows you to overcome the obstacles, when several individual departments implement strategies, corporate actions lack coordination and may act at cross-purposes. 
A corporate strategy department functions as a coordinating body, developing and implementing strategies that satisfy the objectives of individual departments as well as promoting overall corporate goals (Kvint, Vladimir, 2009).

In light of the above definitions, the application of strategies and corporate planning in the day to day management of business entity gives efficiency. The prosperity and prospects of Coca-cola soft drink, Maggi cubes for cooking, the beverage tea drinks Ovaltine and Milo in the target markets comes from strategies and corporate planning. These efforts could be seen in the published statement of annually accounts in vision, mission, purpose, strategic priorities, frame-woks, community trust, consumer relevance, and preference, also in leadership profile among others from the MNCs. Their vision is to become the undisputed leader in every market in which they compete as well as bring togetherness, spread happiness and inspire a better future. Their purpose it's what motivates people to make a meaningful contribution to business and society, refresh consumers, partner with their customers, reward stakeholders, and enrich the lives of local communities. Their Mission of authenticity, Excellence, Learning, caring for people, performing as one, winning with their customer are their values. The application of strategic management and corporate planning these are the deoxyribonucleic acid (DNA) of their continuous existence in efficiency which is very essential to future success. The DNA in this case has to work physical application of strategies and corporate planning in the day to day management of business entity in order to sustain with the prevailing economic business trends.

\section{Strategic management and corporate planning guide production and marketing outreach}

The direction of strategic research also paralleled a major paradigm shift in how companies competed, specifically a shift from the production focus to market focus. The prevailing concept in strategy up to the 1950s was to create a product of high technical quality. If you created a product that worked well and was durable, it was assumed you would have no difficulty profiting. This was called the production orientation. Henry Ford famously said of the Model T car: "Any customer can have a car painted any color that he wants, so long as it is black.

Management theorist Peter F Drucker wrote in 1954 that it was the customer who defined what business the organization was in. In 1960 Theodore Levitt argued that instead of producing products then trying to sell them to the customer, businesses should start with the customer, find out what they wanted, and then produce it for them. The fallacy of the production orientation was also referred to as marketing myopia in an article by Levitt.

\section{Focusing on a cost efficiency mindset}

Managing cost effectively is an essential part of long-term strategy for market leadership and sustainable growth aimed to make the business more competitive by creating a lean organization that's able to exploit efficiencies across targets markets. The focuses are on tight working capital management, operating expenses control, strong and sustained free cash flow generation. There is a managerial efficiency when appropriately put in place in any organization to stem up the prospects and viability of business. It also gives the company an edge, irrespective of trends in an economy to excel in the target's markets at any place.

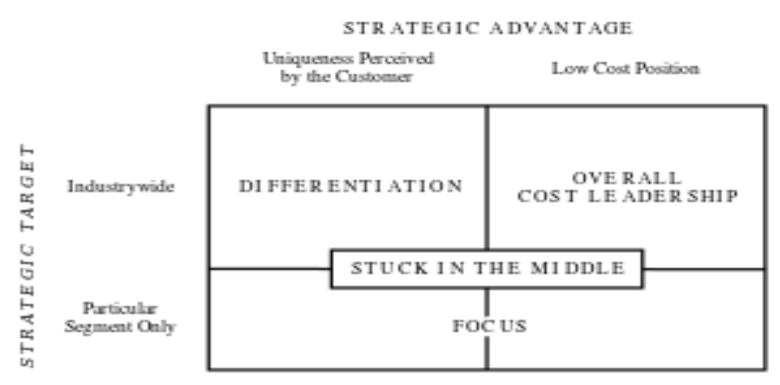

Source: https: en.Wikipedia/ wiki/File 
DOI: $10.21522 /$ TIJAR.2014.06.01.Art005

ISSN: $2520-3088$

\section{Michael porter's three generic strategies}

Porter wrote in 1980 that strategy target either cost leadership, differentiation, or focus. These are known as Porter's three generic strategies and can be applied to any size or form of business. Porter claimed that a company must only choose one of the three or risk that the business would waste precious resources. Porter's generic strategies detail the interaction between cost minimization strategies, product differentiation strategies, and market focus strategies.

The progress of strategy since 1960 can be charted by a variety of frameworks and concepts introduced by management consultants and academics. These reflect an increased focus on cost, competition and customers. These " $3 \mathrm{Cs}$ " were illuminated by much more robust empirical analysis at ever-more granular levels of detail, as industries and organizations were disaggregated into business units, activities, processes, and individuals in a search for sources of competitive advantage.

\section{The concept of effective strategic management and corporate planning}

Businesses of all sizes use corporate planning to identify, build capacity and carry out activities that will bring them closer to the company's goals. They use basic planning strategy concepts to determine how the future may be different from the past. Make choices about the courses of action that will yield the most valuable advantages. They set priorities and evaluate opportunities. They put in place plans that exploit the most promising opportunities while controlling risk. At the completion of the activities in the plan, the company be in a stronger position (Bert Markgraf, 1980). The following concepts are the works of Bert Markgraf about corporate planning:

\section{Goals and targets}

The idea of developing plans to reach defined goals is a basic planning concept. The first step is to establish or identify overall goals. These are divided into specific, individual targets that the company must achieve. In addition to measurable values, plans with goals and targets usually have a deadline and a cost framework.

\section{Situational analysis}

To reach goals, the business must have a clear idea of the starting point. Planners perform an analysis of the company's current situation, often with the concept of identifying strengths, weaknesses, opportunities and threats. Such a SWOT analysis looks at current factors and points the way forward. The company chooses the path that leads to the greatest benefits.

\section{Strategies and tactics}

Strategies are the action plans that lead to the desired results in terms of the overall goals and targets. Tactics characterize the actions that lead to successful implementation of the strategies. If the goal is to double sales and the SWOT analysis shows that a competitor has cost advantages, an effective strategy might be to emphasize product features or quality. Corresponding tactics are to advertise the product characteristics, obtain expert endorsements and offer samples to key media personalities (Brian Hill, 2013).

\section{Plan for execution}

Once the strategies and tactics are clear, planners must develop the concept for the implementation of the strategies. They have to plan for assignment of personnel, use of resources and create a schedule. Each action and tactic have to fit into an integrated plan.

\section{Controls and reporting}

The concept of controls is a key part of corporate planning. The overall plan has to include measures that allow for management to exercise control of the plan's implementation. Typical controls are signing rules and spending limits. Accurate reporting of variables and performance indicators is necessary for the effective operation of the controls. 


\section{Evaluation}

The overall plan has to provide for an evaluation of the initiative once it is complete. Typical planning calls for a comparison of the targets with the actual values. The concept of an evaluation of the effectiveness of the overall plan leads to learning and an improvement in future planning activities.

Creating strategic corporate plans has different effects on management efficiency, depending on when you institute your plans and what autonomy you give managers to vary from their current annual goals. Developing corporate plans in conjunction with a review of departmental goals, budgets and resources will help you determine how to best implement new objectives for your business (Sam AsheEdmunds, 2012).

\section{Strategic management and corporate planning actions steps adopted by the multi- national's organization in nigerian and the success story factors so far}

The MNC organization is one of the world's largest products producers that has been in existence for decades without losing value world -wide. Coca-Cola is the most popular and biggest-selling soft drink, like-wise Maggi cubes for cooking. They are household consumer goods available in every country. The internet report to date shows that some of the products production has been since the 1950s. However, the big question especially for. Coca-Cola is "what makes these products brands so popular? Why are they preferred? Many attributed the success to the superior formulation of the products, the strategic management, corporate planning in operation and marketing capability of the company. In fact, it is remarkably speculated that the owners of the companies jealously guard the products recipe so that competitors cannot lay a hold on it. The main ingredients in these products are sent as syrup to factories all over the world which included in the formulation. But apparently it is not just their formulation that makes it superior brands. It is worthy to note, that hundreds of managers, many of them are revered scientists and engineers who had worked for and left the business world-wide. And these smart experts worked with the formulation as:

- Laboratory Managers

- Technical Managers

- Quality Control Managers

- Products Analysts

- Brands inspectors

- Research and Development (R\&D) Managers.

In doing their daily work routine/ functions, they came face to face with the recipe:

- Worked with recipe/ ingredients

- Analyzed the recipe/ Ingredients

- Worked to improve recipe/ ingredients through research and development (R\&D).

- In terms of the ingredient sourcing and formulation, these same experts:

a) Analyzed the source of ingredient supply; b) prequalified suppliers; c) evaluated storage conditions; and d) got the best prices for ingredients. In order words, these experts know the ingredients that make up the formulation, know the suppliers who supplied at the best prices, and knew the addresses of these suppliers.

Their current employees and retired experts may know everything about the formulation, manufacturing, and marketing of the products brand. But why is it same people cannot duplicate successful the products brand after they exit? The construed reason is that it is not just the formulation of a product that makes it a great brand. Apparently, it goes beyond that. The success story factors include the combination of the people, the process, the marketing, and the leadership of organization is what creates great brands. Truly, experts could duplicate the product formulation but would fail in developing the strategic capacity, capability and innovative muscle to duplicate the branding.

The Multi-nationals' companies (MNCs) continually invest on its employees and generally strategized operations. The company employs great people who contribute great ideas and concepts to make the brand even greater by imbibe ding strategic management and corporate planning to: a) develop a product that meets the need of target market; b) employ the right people; c) invest in the right people; d) adopt a business philosophy that supports unfettered growth; e) invest in strategic branding; f) win with consumers; g) be market driven; h) has performance driven; and i) rewards excellent performance. 
DOI: $10.21522 /$ TIJAR.2014.06.01.Art005

ISSN: $2520-3088$

Winning with their customers: The customers are at the heart of everything they do. Values are deeply embedded in their strategic framework that aims to deliver superior value every day in every key area.

\section{The methodology of study}

Working in consonance with the objective of this paper to show case the relevance of strategic management and corporate planning using the Multi-Nationals products as the case study. The technique of data collection and data analysis approach adopted in this section include: Desk review of literature on strategic management and planning, the development of data capturing tool; and reviewed organizational, institutional, Published Statement of accounts and strategic management/operational framework.

The applied tools developed-questionnaires as well as discussions and interviews with Consumers, costumers, general public opinion and stakeholders to gather the necessary information. Accordingly, the key findings and analysis on the questionnaires are consistent with the objective of the paper.

Furthermore, the methodology combines qualitative and quantitative methods including fact-finding missions, executive opinion surveys and the general level surveys. The data collected and analyzed are sourced from both surveys and documentary reviews. The survey covers the spectrum of manufacturing organizations and enterprise sizes of Multi-nationals' organization at all level in the country. The study employed the use of primary data through questionnaires.

The population sample of the study is staff and dealers in Multi-National Company's products. The data collected were analyzed with the use of statistical formulae of standard deviation. The population size total was 101 among the four categories staff in the Multi- National Companies (Blue Chip Companies) whole sales distributors, Retailers and Consumers/ Communities where the company is situated. While the sample size totals were fifty (50) on which the questionnaire were distributed and forty (40) questionnaire were returned.

Table 1. Questionnaire distribution and returns

\begin{tabular}{|l|l|l|l|l|l|l|}
\hline Designation & Population & $\begin{array}{l}\text { Expected } \\
\text { sample }\end{array}$ & $\begin{array}{l}\text { Actual } \\
\text { Response }\end{array}$ & $\begin{array}{l}\text { Refusal } \\
\text { rate }\end{array}$ & $\begin{array}{l}\text { Expected } \\
\text { Actual\% }\end{array}$ & $\begin{array}{l}\text { \% } \\
\text { Refusal }\end{array}$ \\
\hline Staff/ Officers & 5 & 2 & 2 & - & 100 & - \\
\hline Dealers & 9 & 4 & 4 & - & 100 & \\
\hline Customer & 14 & 6 & 4 & 2 & 66.67 & 33.33 \\
\hline $\begin{array}{l}\text { Communities' } \\
\text { \& General } \\
\text { Public }\end{array}$ & 73 & 38 & 30 & 8 & 78.94 & 21.05 \\
\hline TOTAL & $\mathbf{1 0 1}$ & $\mathbf{5 0}$ & $\mathbf{4 0}$ & - & - & - \\
\hline
\end{tabular}

\section{Test of research hypothesis}

The hypotheses tested by the research work are: null hypothesis (Ho) and the alternative hypothesis (Hi) which denotes the explanation not covered by the null hypothesis. The rejection of the null hypothesis (Ho) will naturally lead to the acceptance of the alternative hypothesis, (Hi).

\section{Hypotheses 1}

Ho: That Multi -National Company's do not pay adequate attention in the use of strategic management and corporate planning as a tool in the development and producing of Coca-Cola minerals soft-drink and Maggi cube cooking ingredient to make viable the products available at all time.

Hi- That Multi -National Company's do pay adequate attention in the use of strategic Management and corporate planning as a tool in the development and producing of Coca-Cola minerals soft-drink, Maggi cube cooking ingredient to make viable the products available at all time.

In response to the questionnaires designed to test hypothesis 1 (one) to probe whether company Multi -National Company's takes strategic management and corporate planning concept in the development 
and production their great brands. The data collected from there is tabulated and analysed in table 2 below.

Table 2. Analysis of questionnaire reponses

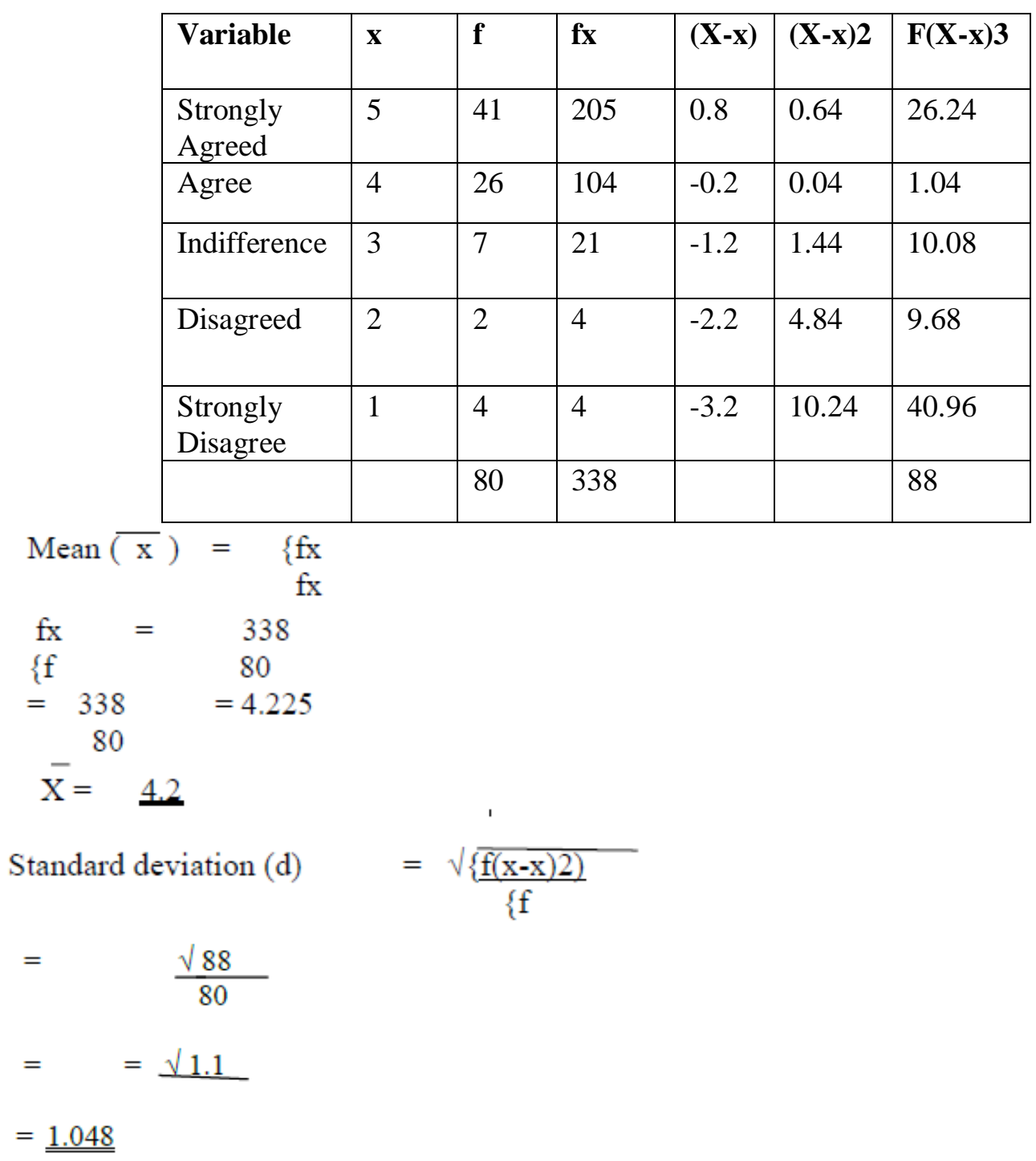

From the above analysis, the average weight is 4.2 which is approximately the weight allocated to agree. The rate of dispersion is 1.048 which is for not to agreed.

This shows that Multi -National Company's pays adequate attention to the use of strategic management and corporate planning in the development and producing Coca-Cola minerals soft-drink, Maggi cube cooking ingredient to make viable products available at all time. Therefore, Ho is rejected and the alternative hypothesis Hi was accepted.

This was further represented in pie chart graph to show the level of strongly agreed and not agreed for clearer understanding. 
DOI: $10.21522 /$ TIJAR.2014.06.01.Art005

ISSN: $2520-3088$

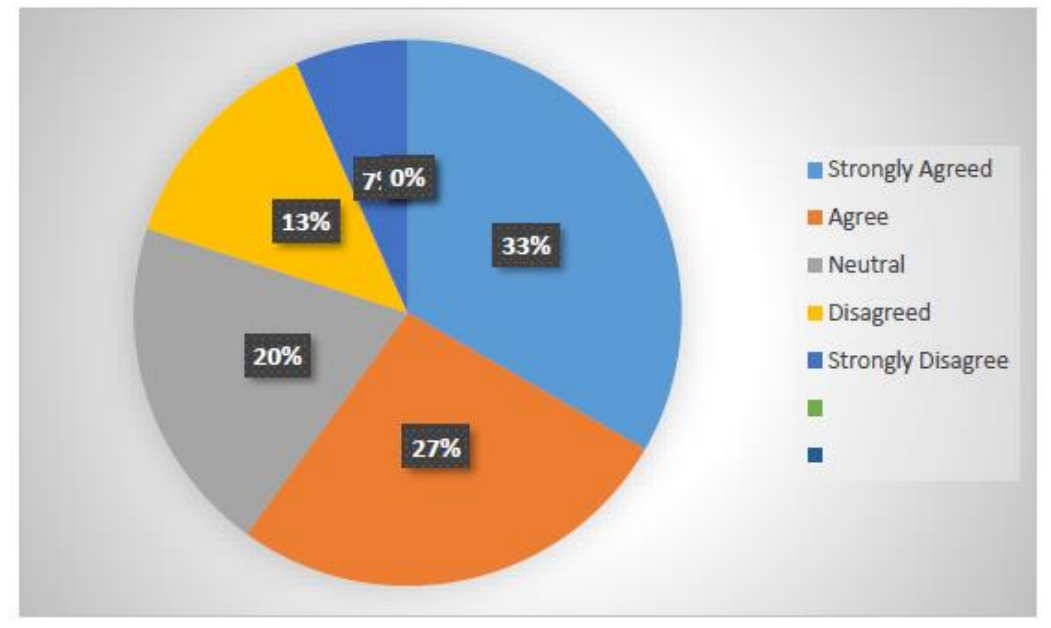

Pie chart graph of the data analysis representation showing level agreed or not agreed and etc.

\section{Hypothesis 2}

Ho: That adequate application of strategic management and corporate planning in business will not make continuous existence of organization product services to be at all-time efficient and effective.

Hi: That adequate application of strategic management and corporate planning in business will make continuous existence of organization product services to be at all-time efficient and effective.

Answers from data collected from questionnaires: That adequate application of strategic management and corporate planning in business will or not make continuous existence of organization product services to be at all-time efficient and effective designed to test the hypothesis 2 above before acceptance or rejection. The tabulation of the data response is shown in table 3.

Table 3. Analysis of questionnaire responses

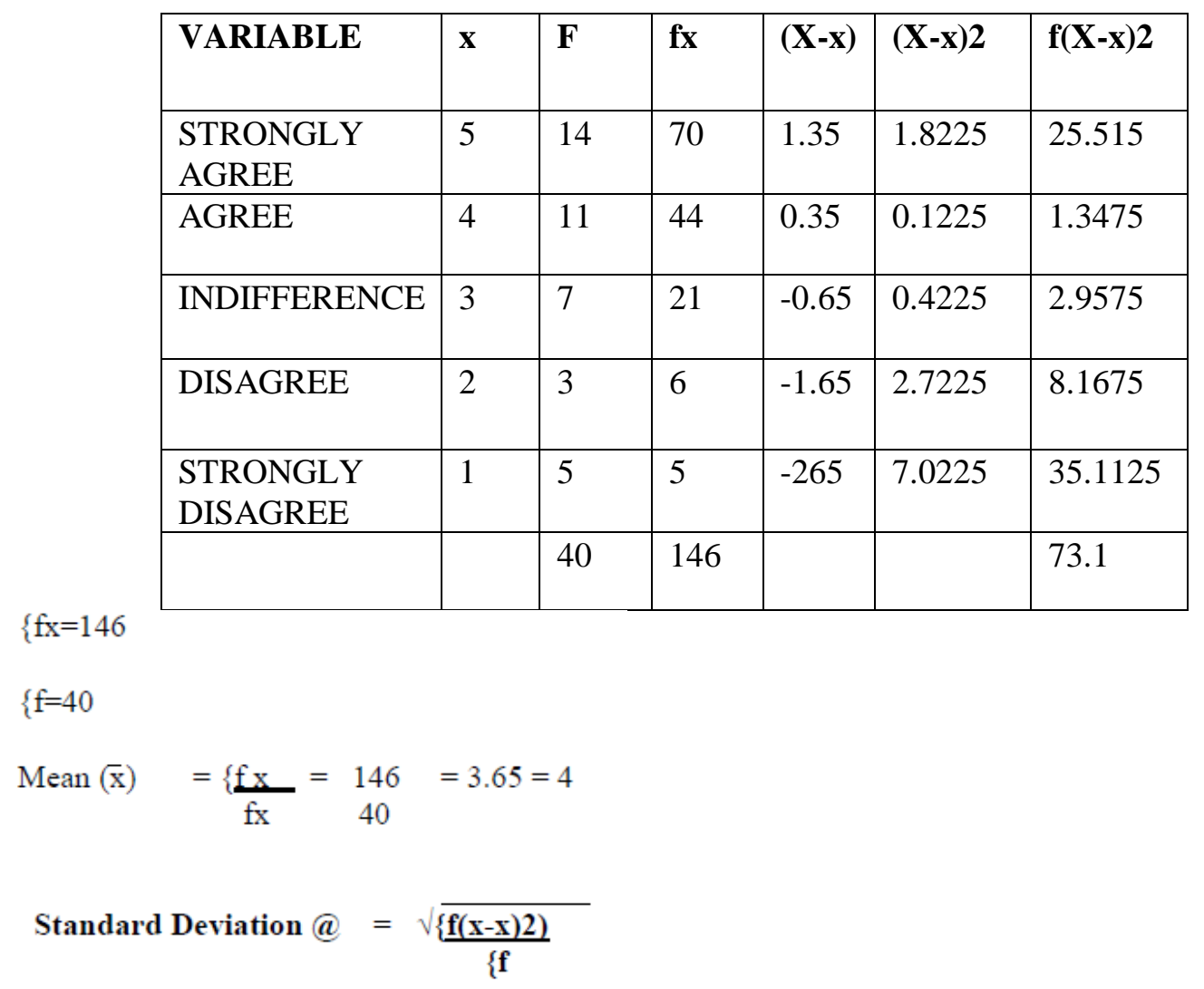




$$
\begin{aligned}
\{\mathrm{f}(\mathrm{x}-\mathrm{x}) 2 & =73.1 \\
\{\mathrm{f} & =40 \\
\text { Standard Deviation } & =\frac{\sqrt{\mathbf{7 3 . 1}}}{40} \\
& =\sqrt{1.8275}=\underline{\underline{1.35}}
\end{aligned}
$$

From the analysis, the average weight is 3.65 approximate to 4 allocated to agree. The rate of dispersion is 1.35 was allocated to disagreed. It is therefore confirmed that considering the fact that adequate application of strategic management and corporate planning in business make continuous existence of organization products services to be at all-time efficient and effective. The null hypothesis Ho was therefore rejected and the alternative $\mathbf{H i}$ is accepted.

The data was further tested by plotting a line graph of the analysis using the variables and mean (x) and frequency (f) responses.

\section{Line graph used to show level of agreement for hypotheses 2}

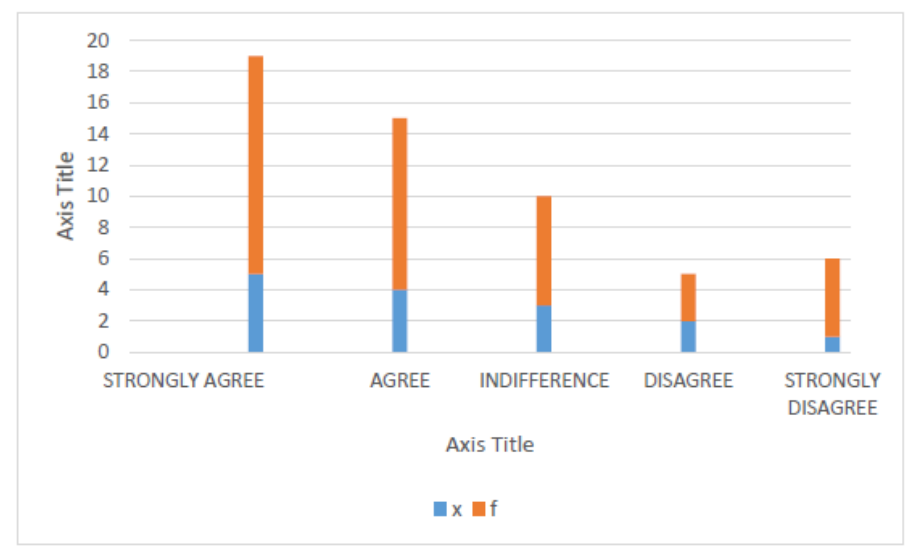

A simple Line graph of data analysis testing whether it is true that: That adequate application of strategic management and corporate planning in business will make continuous existence of organization product services to be at all-time efficient and effective.

\section{Discussions, findings and comments}

From the research study, the summary is to facilitate the readers understand how strategic management and corporate planning in business imparted the company to exist in perpetuity with viable products at all-time despite the changes or trends in the business climate or environment. To achieve the aim of the study, the research attempted to cover the following:

- Assessing the effect of strategic management and corporate planning as tools in making company's business products viable, available and continuously efficient at all-times, while answering the question on:

- How strategic management and corporate planning makes business products to be viable and available at all time?

- What were the major principles of strategic management and corporate planning that was taken by management of the company?

- What roles were the leadership played in order to achieve the objective of the company using strategic management and corporate planning policies

- Whether the strategic and corporate management designed by the company actually assisted staff output at all-times

- Whether the management, leadership operating objectives is always available to improve the company operations and services at all-times

- How the use of strategic management principles and corporate steps taken played vital roles to achieve the company continuous existence. 
DOI: $10.21522 /$ TIJAR.2014.06.01.Art005

ISSN: $2520-3088$

The questions led the researcher to develop two pairs of explanatory statements in form of hypothesis 1 and 2 which were tested with data collected from primary and secondary sources.

This therefore led the research to conclude that the company pays adequate attention to the use of strategic management and corporate planning techniques in producing Coca-Cola minerals soft-drink and Maggi cube cooking ingredient.

The research is an empirical type through a survey research. Its finding arguably encourage company to invest in applying strategic management and corporate planning in making great brands of products that can existing in perpetuity.

\section{Recommendations}

The under listed recommendations are made in the light of the study findings:

For company to build capacity and create great bands, embarking on realistic and systematic implementation of strategic management and corporate planning principles is inevitable.

For continuous existence any company that will want to be in perpetuity need to ensure good strategic management and corporate planning formulation and implementation to enhance operations effectiveness.

The application of strategic management and corporate planning is desirable for companies to continue being in operations despite the economic business trends in place.

Strategic management and corporate planning social corporate responsibilities to the environment of business location encourages existing and potentials customers to be imparted with the organization products and services.

\section{Conclusion}

This study has shown possible four main important outcomes from the Multi-National Company's using strategic management, corporate planning for business excellence. How it imparted highperformance operations and dividends by manufacturing organization in desirous to retain high market share leadership. To sustain continuous growth in today's business world, strategic management and high-performance outcomes connote that:

(a) There is strong need for manufacturing organizations operating in a dynamic environment wrapped with economic uncertainty to embark on realistic and systematic implementation of strategic management and corporate planning principles that would be able to meet challenges of the business at all times; (b) For any serious business development and market leader, that desires continuous existence and growth in perpetuity, there is stronger need to ensure a good strategic management and corporate planning implementation to enhance goods and services provision at all times;

(c) The application of strategic management and corporate planning is desirable for companies to continue being in operations no-matter the economic business trends at any period; and (d) Strategic management and corporate planning enables organizations perform their social corporate responsibilities to the environment of the business location which in turn motivate the citizens to patronize and remain loyal to the organizations' products brands at all times.

\section{References}

[1]. August W. Giebelhaus (May 13, 2008). "Coca-Cola Company". The New Georgia Encyclopedia. Georgia Humanities Council.

[2]. Brian Hill (2013) "The Making of a Bestseller," "Inside Secrets to Venture Capital," "Attracting Capital from Angels" and his latest book, published in 2013, "The Pocket Small Business Owner's Guide to Business Plans."

[3]. BCG-Philip Evans-Rethinking Strategy for an Age of Digital Disruption-March 2001.

[4]. Cameron, Bobby Thomas. (2014). Using responsive evaluation in Strategic Management. Strategic Leadership Review 4 (2), 22-27.

[5]. David Besanko, David Dranove, Scott Schaefer, and Mark Shanley (2012) Economics of Strategy, John Wiley \& Sons, ISBN 978-1118273630.

[6]. The Economics - Strategic Planning - March 2009.

[7]. Ghemawat, Pankaj (Spring 2002). "Competition and Business Strategy in Historical Perspective". Business History Review. SSRN 264528ฮ. 
[8]. Hill, Charles W.L., Gareth R. Jones, Strategic Management Theory: An Integrated Approach, Cengage Learning, 10th edition 2012.

[9]. Kemp, Roger L. (2008) ."Strategic Planning for Local Government: A Handbook for Officials and Citizens," McFarland and Co., Inc., Jefferson, NC, USA, and London, England, UK, 2008 (ISBN 978-0-7864-3873-0).

[10]. Kvint, Vladimir (2009). The Global Emerging Market: Strategic Management and Economics. Routeledge. [11]. Laszio, Chris and Zhexembayeva, Nadya (April 25, 2011) 'Embedded Sustainability: A strategy for market leaders"' The European Financial Review.

[12]. Laszio, C. and Zhexembayeva, N. (2011) ''Embedded Sustainability: The Next Big Competitive Advantage. Stanford, CA: Stanford University Press. ISBN 0.804-77554-0.

[13]. Michael Porter (1996). What is Strategy? -Harvard Business Review-November 1996.

[14]. Michael Porter-Strategy and the Internet-Harvard Business Review-March 2001.

[15]. Mickeown, Max, The Strategy Book, FT Prentic Hall, 2012.

[16]. Mintzberg, Henry (1987). "Why Organizations Need Strategy". California Management Review (Fall 1987).

[17]. Mintzberg, Henry and, Quinn, James Brian (1996). The Strategy Process: Concepts, Contexts, Cases. Prentice Hall. ISBN 978-0-13-234030-4.

[18]. Mintzberg, Henry (1973). The Nature of Managerial Work, Harper and Row, New York, 1973, page 38. [19]. Mulccaster, W.R. (2009). Three Strategic Frameworks, 'Business Strategy Series, Vol10, No 1, pp 68-75. [20]. Nag, R.; Hambrick, D. C.; Chen, M.-J (2007). "What is strategic management, really? Inductive derivation of a consensus definition of the field"(PDF).Strategic Management Journal.28 (9): 935-955. doi:10.1002/smj.615. Retrieved October 22, 2012.

[21]. Rumelt, Richard P. (2011). Good Strategy / Bad Strategy. Crown Business. ISBN 978-0-307-88623-1.

[22]. Scott Armstrong J. \& Kesten C. Greene (2007) 'Competitor-oriented Objectives:

[23]. The Myth of Market Share'” (PDF). International Journal of Business. 12 (1): 116-134. ISSN $1083-4346$.

[24]. 'Taking Care of Business, 1995- 2005', Science Watch. Thomson Scientific. November-December 2005 , Retrieve 2012-01-26.

[25]. Traverse, D. (2000). Outsmarting Goliath, Bloomberg Press, Princeton.

[26].Zhexembayeva, N. (2014). Overfished Ocean Strategy: Powering Up Innovation for a Resource-Depleted World. San Francico, CA: Berret-Koehler Publishers. ISBN 1 609-94964-1. 


\title{
The Challenges in Analyzing Project Management Principles in Service Delivery in the Issuance of Driver's License (A Case Study the Driver's and Vehicle Licensing Authority (DVLA) of Ghana.)
}

\author{
Article by Daniel Quansah \\ MBA General Management, Texila America University \\ E-mail: danielquansah6@gmail.com
}

\begin{abstract}
Project management is the discipline of planning, organizing, securing, managing, leading and controlling resources to achieve specific goals (kshama, 2018). Driver and Vehicle Licensing Authority is a semi-autonomous public sector organization that promote good driving standards and establish methods for the training and testing of driving instructors and drivers of motor vehicle and riders of motor cycles in Ghana. Of recent, there have been a lot of road accidents as a result of poor driving practices. This study is to address some of the contributing factors by analyzing the project management principles in the service organization by focusing on the process of issuing driver's license by DVLA. Several literatures assess the concept of driving license.

300 respondents made up of employee and customers of the firm were sampled for the study. The mix method was employed in collection of data whilst the purposive sampling and simple random sampling techniques were used. The findings of the study indicate that an applicant is eligible for a driver's license if he/she is 18 years and above and must have attended an accredited driving school.

The study found that, there are delays in the operations of DVLA due to the manual process they employ, the trend been currently used to register applicant and book them for exam and driving test as well as the time wasted in the printing and issuance of driver's license. Customers are very dissatisfied with the manure of operation especially customer service and accessibility to information in the company.
\end{abstract}

Keywords: Applicants, Driver and Vehicle licensing Authority, Probationary, Satisfaction, Semiautonomous.

\section{Introduction}

Many organizations around the world keep failing, resulting in loss of millions of dollars due to poor service delivery. This persisting challenge has led many project management professionals to attempt to identify the critical factors that needs to be tackle head-on to produce a successful project management outcome. Smit and Cronje (2002) were of the view that firms are challenged with rapid growth in products, rising complexity and a threat from global competitions due to advancement in technological innovations. With focus for organizations to effectively secure their own position in the competitive market, accurate strategies are developed and implemented from the corporate level through principles in project management, which serves as an effective tool to attain competitive advantage.

The Driver and vehicle Licensing Authority (DVLA) is a semi-autonomous public sector organization under the Ministry of Transportation that promote good driving standards and establish methods for the training and testing of driving instructions and drivers of motor vehicles and riders of motor cycles and the issuance of driver's license in the country. In that view, DVLA is endorsed as the only official firm with the purpose to support high-quality driving values and road worthy vehicles. Its task also comprises of ensuring the safety of vehicles and to provide other related factors that promote effective driving and reduce the rate of accidents on the road (Parliament of the Republic of Ghana Act 569.1999).

To better provide high quality of service delivery, productivity and customer satisfaction in their operations, DVLA introduced a computer-based technology system with the partnership of a private 
firm known as the Authority and Fleet Technology Limited. This development was done by the DVLA to eliminate the manual process used in training and to provide a more flexible training system where applicants go through a theory driving test. The manual process which was used by the firm was confronted with several challenges including fraud, human interference and influence and poor service delivery. The adopted technology seeks to address such challenges and ensuring value for money, transparency and accountability in the administration of the test. This technology system will go a long way of reducing road accidents, since drivers will be trained in accordance with the limit of road usage.

Furthermore, most empirical work conducted has not examined the challenges face in the service delivery in the operations of DVLA creating a huge research gap that needs to be investigated. The study therefore seeks to assess the challenges of service delivery in the issuance of license at the Driver's and Vehicle licensing Authority and the role of project management principles.

\section{Research questions}

- What is the procedure involved in the issuance of driving license at DVLA?

- What are the challenges associated with the issuance of driving license?

- What is the trend analysis in the issuance of driving license at DVLA?

- What is the satisfaction level of customers in regards to DVLA customer service?

\section{Literature review}

This chapter focuses on the theoretical review which analyze the concept of project management and its principles, the types of driving license issued and the reviews of the challenges that DVLA faces in the issuance process.

\section{Concept of project management}

Project management is a discipline of planning, controlling, organizing and managing the different types of resources to achieve the specified project goals (Laslo 2010). Project management ensures all stages of the project follow a systematic approach of careful planning, monitoring and measuring (Murphy and Ledwith 2007).

\section{Project management in the service sector- DVLA}

\section{Classes/types of licenses}

Every country has its system of issuing driving license, but in both developed and developing nations, most of these licenses are classified into six parts, which include the class $(1,2,3,4,5 \& 6)$. These classes of license allow drivers to drive both light and heavy vehicles. For instance, the class 1 driver's license allows the driver to drive light motor vehicles like moped, motor bikes among others whiles the class 2 allows drivers to drive vehicles like saloon cars and other light vehicles. Moreover, classes 3,4,5 \& 6 allows their holders to drive heavy vehicles like pick-ups, articulators, trailers among other heavy vehicles. According to Gutter (2000), from class 3 to 6 licenses gives drivers the permission to use heavy vehicles that are mostly different depending on the class of the license.

Depending on the country, most licenses are issued from the age of 16 but in Ghana, license are issued from the age of 18 by law and includes all classes of license. Before an applicant can be successful in acquiring a license, then the applicant would have gone through these three stageslearners license, restricted license and full license. (Dioff, 2001).

\section{Endorsements}

In addition to the six classes, driving some types of vehicles or service machinery requires license endorsements in most developed countries. These can be gained once the appropriate course for the endorsement has been completed. Before an applicant is endorsed, the applicant must be knowledgeable in the carrying goods that are hazardous, the use of the forklift and must be instructor for using a roller and recovery vehicles. 


\section{Concept of driving licensing}

Having an official form of identification is imperative in the both developed and developing countries for the legal, travel and government purposes. The increases in illegal immigration and security concerns have caused officials to evaluate the role of driver's licenses as forms of identification with legal and illegal immigrants (Shults \&Ali, 2010). Traditionally driver's licenses have been granted to legal citizens; however, several countries have adopted systems making it easier for legal immigrants to qualify for distinct certificate to drive. This has sparked a national debate regarding the proper use of driver's licenses as identification (Daily Graphic, 18 ${ }^{\text {th }} \mathrm{July}, 2010$ ).

In some developing countries like Ghana, South Africa, Kenya and Zambia, driver's licenses are often required for travels within, purchasing items such as alcohol or cigarettes confirming one's identity when using a debit or credit card (Anti \& Sarpong, 2010). Many countries including Ghana, issue state IDs for those with no driver's license to serve the same identification purposes as a driver's license because it is almost impossible to conduct daily business without identification.

\section{Driving licensing system in ghana}

In Ghana, issuing license is considered officially a state matter. In each region, driving license is issued by the regional transport Offices (RTOs). Unfortunately, prior driver education is not mandatory for getting a driver license. All matters related to driver education and licensing in Ghana are presently regulated by the Road Traffic Act 2004, Act 683. As per sub-section (1) of section- 4 of the Road Traffic Act 2004, Act 683, a motorcycle with engine capacity not exceeding $50 \mathrm{cc}$ and without gear (provided parents/guardian consent obtained) may be driven in a public place by a person after attaining the age of 18 years. This is potentially hazardous as young drivers are more involved in crashes and two-wheeler drivers are among the vulnerable road users.

\section{Empirical review}

There have been several empirical reviews on the issuance of driving license in several countries (both developed and developing nation). For instance, due to the competitive nature of every citizen in United States of America to acquire a driving license, most firms who have been authorized to issue driving license are challenged with rapid growth in products, rising complexity and a threat from global competitions due to advancement in technological innovations (Jiot, 2004). Another similar study by Giotter (2005) confirms that with focus for organizations that have been authorized to issue driving license in Australia, and to effectively secure their own position in the competitive market, accurate strategies are developed and implemented from the corporate level through principles in project management, which serves as an effective tool to attain competitive advantage.

\section{methodology of study}

The study was based on a research design that blends both qualitative and quantitative techniques in its data gathering and its analysis. According to Hiloer (2004), the research design provides the researcher the technical techniques that will be used in the analysis and to provide the researcher with solutions in a research. These techniques ensure that the researcher is able to gather sufficient information from its targeted respondents. The qualitative approach was used in gathering data from respondents through questionnaires whiles the quantitative approach was used in gathering data through interviews.

These methods were also used because of the nature in providing an explicit rendering of data from the respondents. In addition, observations of the business of operations of DVLA were made possible due to the use of these techniques. Observation is useful for generating in-depth descriptions of the organizations or events, for obtaining information that is otherwise inaccessible, and for conducting research when other methods are inadequate.

The research was based on both secondary and primary data. The primary data was gotten from the questionnaire and interviews that were administered to respondents during the field work the study made use of secondary sources of information from DVLA. These sources include archived data on staffs and customers of DVLA. Data was collected based on trends of driver's licenses been issued in a specific year, level of customer satisfaction, types of licenses, the procedure of obtaining driving 
DOI: $10.21522 / \mathrm{TIJAR} .2014 .06 .01 . A r t 006$

ISSN: $2520-3088$

license and the challenges faced by DVLA on issuing driver's license. Data collected from the secondary sources significantly complement primary data and enhance the interpretation of the results (Batsa, 2008).

Due to the nature of the study, two separate sampling techniques were selected based on the staff and customers of the organization. The sampling techniques employed in this study are purposive sampling and simple random sampling. Lead (2005) defines purposive sampling as a type of sampling technique that involves the selection of particular types of respondents for the completion of a research work. In this regard, 300 respondents who are customers of the DVLA were selected for the completion of the study.

The research instrument that was employed for the study was questionnaire. The questionnaire encompassed both closed-end and open-ended questions. The questionnaires are structured in way that will reflect the significance of the research questions. The questionnaire to the study was administrated by the researcher and based on the sample selected, the research instrument was administered within a three (3) weeks. This period was selected because it afforded both the researcher and the respondents' ample time to complete the questionnaire.

All the data that was gathered from the field work through the administration of the questionnaire was coded and analyzed. The data gathered from the interviews were summarized to make a meaningful statement and the raw data were entered into tables and graphs were drawn to show the pattern of the data.

\section{Results and discussion}

The previous section was on the research methodology where the various research techniques as well as sampling types and the target population were identified and discussed. This section reports on the results on the interviews conducted and questionnaire administered during the field work undertaken to analysis the project management principles in the service delivery of the Driver and Vehicle Licensing Authority of Ghana.

\section{Qualitative data}

Table on qualitative data collection methods

\begin{tabular}{|l|l|}
\hline Methods & Brief explanations \\
\hline Interview & $\begin{array}{l}\text { This involves asking questions, listening to and recording answers } \\
\text { from individuals or groups on structured and semi-structured } \\
\text { format }\end{array}$ \\
\hline observation & $\begin{array}{l}\text { The researcher gets close enough to study subjects to understand } \\
\text { and access tacit knowledge of the subject and in their respective } \\
\text { fields. }\end{array}$ \\
\hline
\end{tabular}

\section{Analysis of data from interviews}

\section{Manual operations of DVLA}

From the onset of the DVLA, the operations of the firm were manually handed by employees. The researcher conducted interviews and observed employees to ascertain the challenges the firm faces.

\section{Flow chart depicting manual operations and durations}

The chart below illustrates the procedure an applicant goes through before obtaining a driver's license by the manual process. 

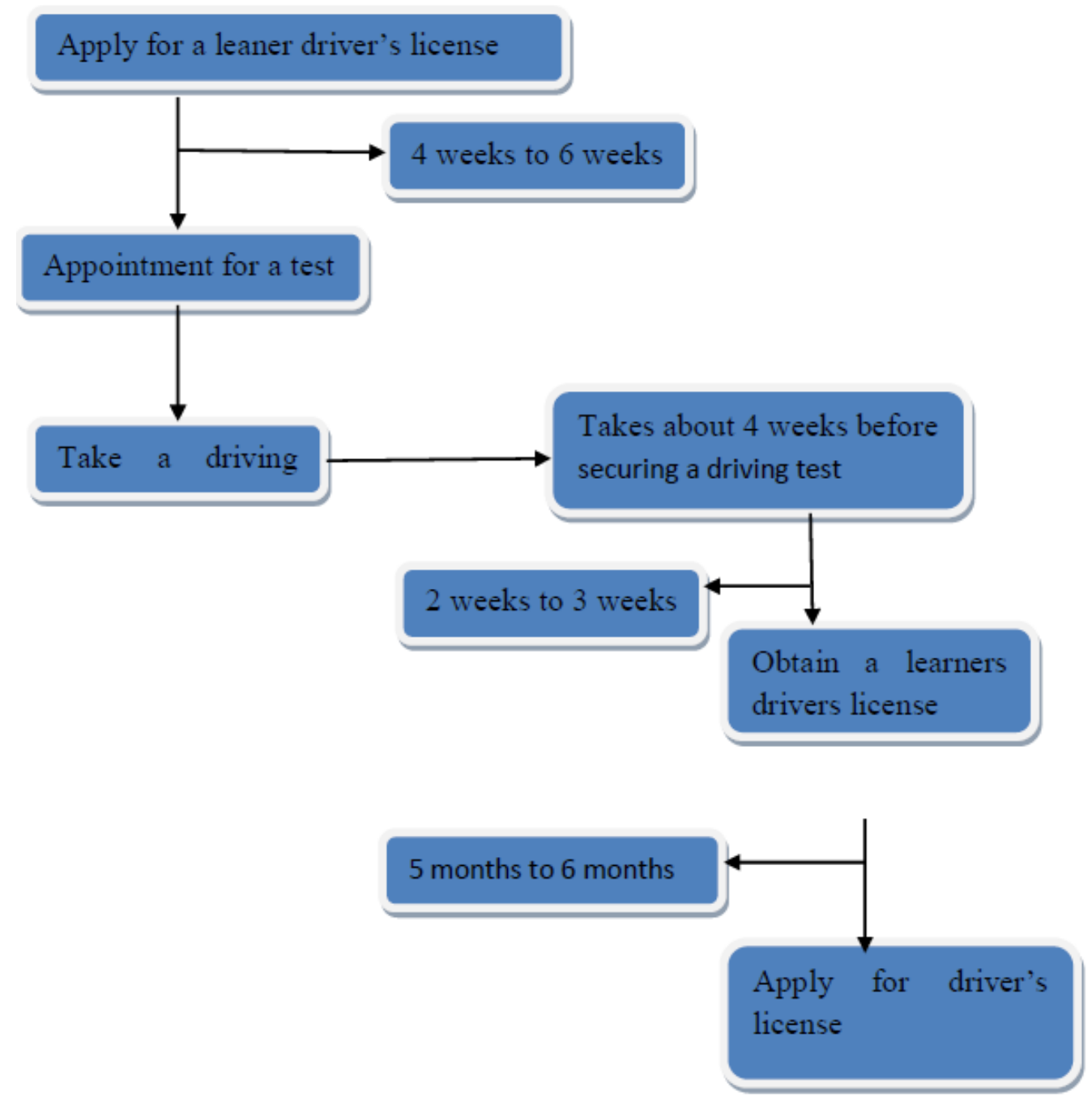

Source: DVLA ARCHIVES.

\section{Interview}

Based on the interview with Mr. David Mensah, and other officials with the license issuance department on the steps and the procedure in obtaining drives license. The following are the information gathered.

It is mandated by law that an applicant must be 18 year of to be able to acquire a license. The official further stated that before an applicant apply for a driver's license, the applicant must first obtain a learners' permit through a recognized driving school. The applicant then makes an appointment for a driving test which takes a span of two weeks for completion.

Furthermore, Mr. Mensah and his colleges explained that after an applicant has completed the driving lesson, the applicant must go through an eye test. A probation driving license is given to the applicant when the sight status is cleared. When an individual successfully completes the driving test, the applicant is been issued with a certificate of competence, which validates the applicant obtaining for a full driver's license. In all, applicants pay appropriate fees in each step they go through to an official bank account of DVLA.

The learner's driving license is used for a period of three months before obtaining a full driving license. A successful applicant of the test leads to a full driver's license, which is mostly valid for a period of six years and renewed every two years. Also, the same procedure can be applied when duplicating for a lost or deface card, a police report and an application for repayment is presented at the regional office of DVLA.

Computerize system flow chart to meet customer satisfaction needs. 
DOI: $10.21522 /$ TIJAR.2014.06.01.Art006

ISSN: $2520-3088$

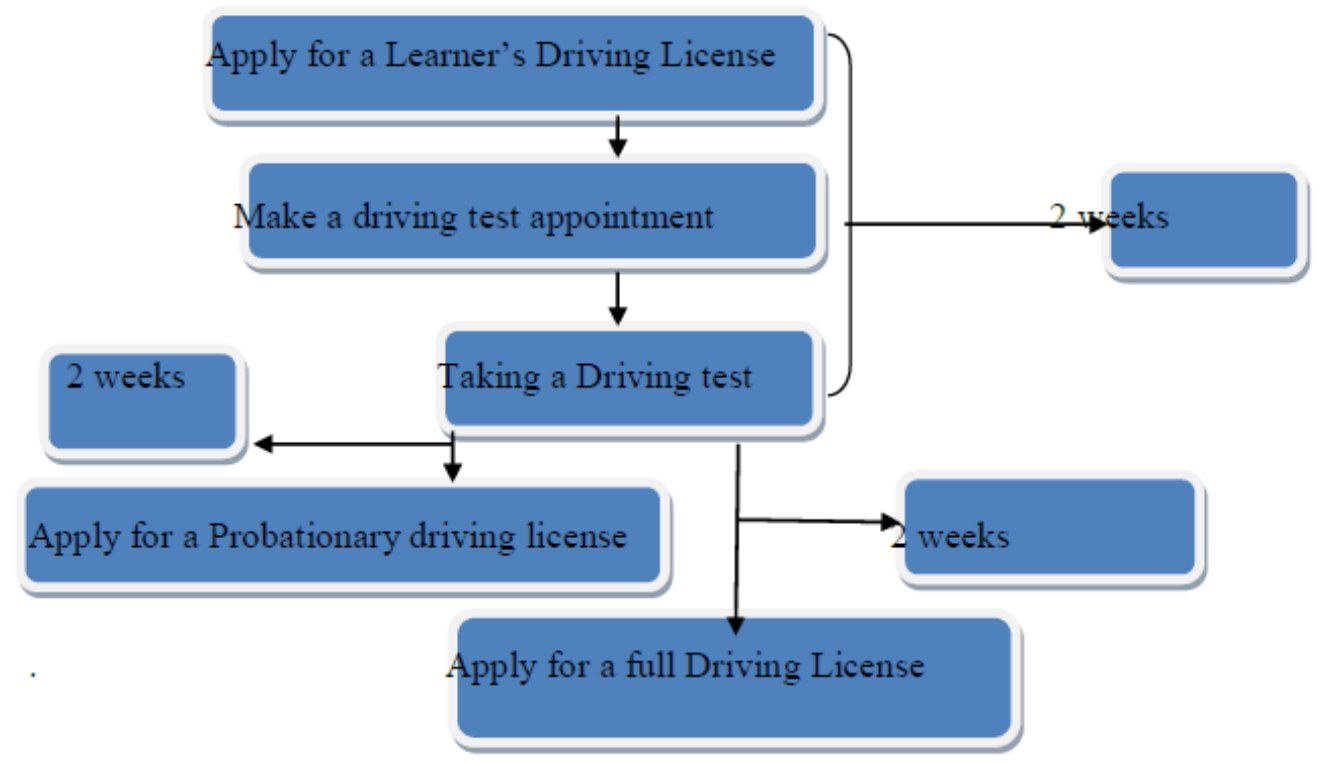

Source: DVLA ARCHIVES.

For DVLA to ensure customer satisfaction and meeting customers targets there is the need for the organization to adopt a simple flow chart through a computerize system of operation that will ensure that customers' needs are met. As illustrates in figure 2; the period to apply for a license and taking a driving test takes 2 weeks only as compared to the two months it takes. This is due to the fact that, when two weeks is applied for applicants to obtain their learner driving license, it will prevent the illegal practice of middle men and eliminate duping of innocent applicant. It should be noted that, most of these applicants pass through the 'back door' or middlemen due to the long periods it takes officials of DVLA to process the driving license for the applicants.

Moreover, the period between taking the driving test and apply for a probationary driving license should take a week instead of the 4 weeks. This will create satisfaction of customers and enhance the productivity of DVLA. In addition, it takes close to 2 months to obtain a full driver's license, but with the new flowchart for DVLA, it was reduced to 2 weeks. It should be noted that, it is the mission and objective of DVLA to see to it that an applicant obtains their license within a period of 3 months. But it has been the norm that it takes some applicants almost 6 to 9 months before obtaining a probation learners license. Therefore, when this procedure is implemented, it will ensure that DVLA achieves its objectives and mission as well. Also, the use of this chart will ensure that, customer satisfactions are met and staffs in the licensing department will be able to meet the 3 months deadline.

\section{Quantitative data}

Table on quantitative data collection methods

\begin{tabular}{|l|l|}
\hline Methods & Brief explanations \\
\hline Survey & $\begin{array}{l}\text { In the survey, a Checklist was used to identify behaviour, } \\
\text { characteristics and other entities }\end{array}$ \\
\hline Questionnaires & A structured checklist was used to gather data \\
\hline
\end{tabular}

\section{Loopholes identified during issuance of driver's license at DVLA}

During the data gathering, it was found that when applicants apply for the learner's license, it took almost two weeks before they can book an appointment for a driving test instead of the normal 2 to 3 days. Also, when an applicant successful passes the driving test, the applicant is supposed to get the temporary license within one week. However, it was found that an applicant waits as long as 2 to 3 months before their license can be ready.

Additionally, it was found that, officials of the DVLA do not follow the laid down procedures for obtaining a license. DVLA services are based on "first come, first serve". But it was found that, some 
officials of DVLA collude with middlemen and take huge sum of money from customers who do not want to partake in the driving test, thereby causing the delay of the applicant who passes through the normal procedure.

\section{Applicant who registered and issued with a driver's license in 2016-2018 in the first quarter}

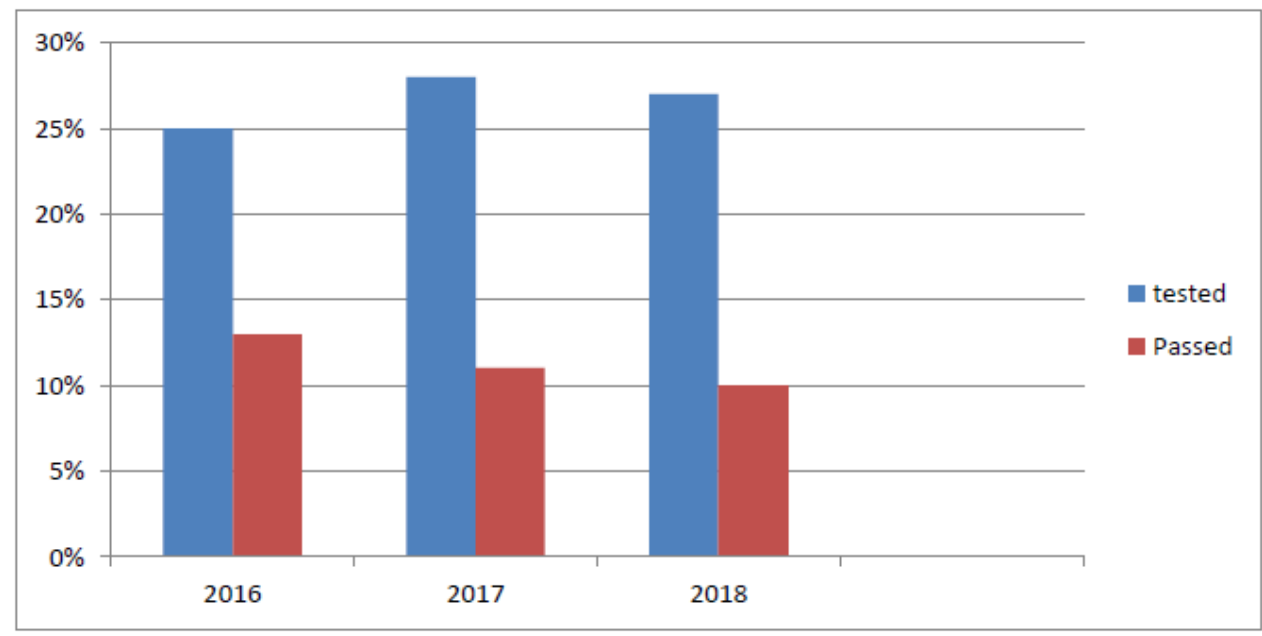

Source: Archived data

The above chart depicts the applicants that registered for a driver's license and were issued with it. The data illustrate a quarterly issuance of license from 2016 to 2018 which implies that the total of 4,589 applied for license in 2016. 1,239 representing 27\% registered for the exams but only $13 \%$ were competent for a driver's license. Also, in 2017, 4,542 represented by $23.5 \%$ registered for the exams and $12.7 \%$ were issued with a driver's license, likewise in 2018, there were 4,101 represented by $23.2 \%$ registered for the exams and $10 \%$ were successful and issued with driver's license.

It can be concluded that, within the Accra district, large number of applicants who registered for an examination for a driver's license failed their exams. Based on the data gathered from officials of DVLA as to why most applicants fails their driving test, they stated that most of the applicants do not prepare adequately for the test and most also failed due to the fact that they do not understand the rules of the road.

Additionally, it can be seen from the data represented that, the trend of driver's license issued follows a downwards trends where it rises and fall within intervals. This rise can be contributed to the massive education by governmental bodies like the Metro Transport Unit, patrol unit of the Ghana police service that ensured that every driver on the road should have a driving permit. In addition, the decline can also be attributed to the unpreparedness of applicants before taking the driving test. It can also be as a result of lack of availability of learning materials for applicants. 
DOI: 10.21522/TIJAR.2014.06.01.Art006

ISSN: $2520-3088$

\section{Trend of applicants who apply for a driver's license}

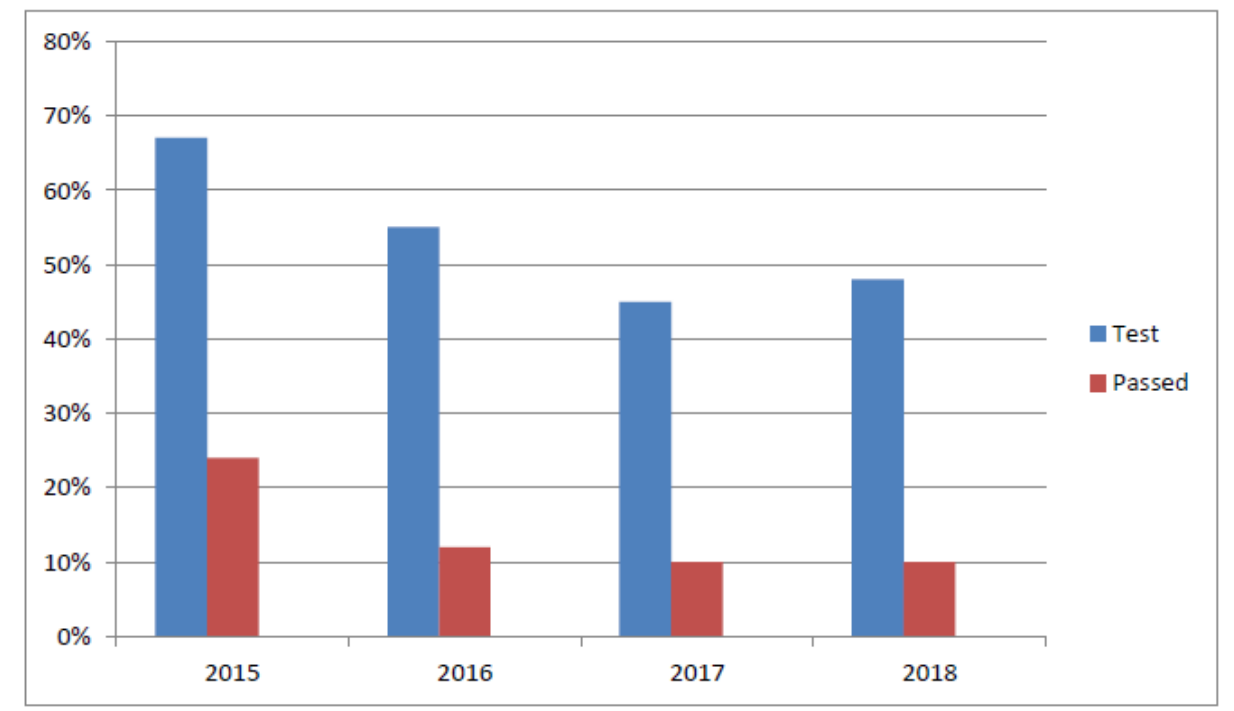

Source: field data

\section{Level of customers' satisfaction with service delivery of DVLA}

Furthermore, questionnaires were randomly distributed among 300 customers of DVLA at the Accra regional office and the outcomes are illustrated below.

\section{Satisfaction of DVLA customers}

\begin{tabular}{|l|l|l|l|l|l|}
\hline Variables & $\begin{array}{l}\text { Strongly } \\
\text { agree }\end{array}$ & Agree & Disagree & $\begin{array}{l}\text { Strongly } \\
\text { disagree }\end{array}$ & Neutral \\
\hline $\begin{array}{l}\text { Are the service at DVLA } \\
\text { reliable }\end{array}$ & -- & $12.1 \%$ & $76.2 \%$ & $11.7 \%$ & -- \\
\hline $\begin{array}{l}\text { Are the officials at DVLA fast } \\
\text { in giving information relating } \\
\text { to any service }\end{array}$ & $8.0 \%$ & $15.9 \%$ & $76.2 \%$ & -- & -- \\
\hline $\begin{array}{l}\text { Do the officials at DVLA have } \\
\text { a positive attitude when i seek } \\
\text { for their assistance? }\end{array}$ & $40.1 \%$ & $15.7 \%$ & -- & $44.2 \%$ & - \\
\hline $\begin{array}{l}\text { Does it take a longer time to } \\
\text { access the service at DVLA }\end{array}$ & $23.30 \%$ & $16.70 \%$ & $60 \%$ & -- & -- \\
\hline
\end{tabular}

The table above illustrates the satisfaction level of customers at DVLA. The customers added that the services of the firm are not reliable and this was agreed by $76.2 \%$ of respondents. The customers explained that they were asked to come for their permanent driver's license within three months, but took them almost 6 to 7 months before having access to it.

Furthermore, $76.2 \%$ of the customers added that officials of the firm are not fast in their service delivery. With this aspect, the customers explained that, it can sometimes take almost 3 to 4 hours before their photograph can be taken. Also 35\% of the customers who came for their permanent driver's license stated that, instead of 3 months grace period issued to them, it took them eight months before their license were issued to them. In addition, $41 \%$ of the customers stated that it took them almost a year before their license was issued to them.

However, $40.1 \%$ of the customers confirmed that, the officials of the firm have a positive attitude when their assistance is needed. Also, $44.2 \%$ of the customers strongly disagreed to the fact that the firm's officials have a positive attitude towards their customers. One particular customer further explained that "some officials hardly 'smile' to them and are very unfriendly". Conclusively, all the customers confirmed that it takes a longer time to have access to the services of the firm". 


\section{Accessibility of service at DVLA}

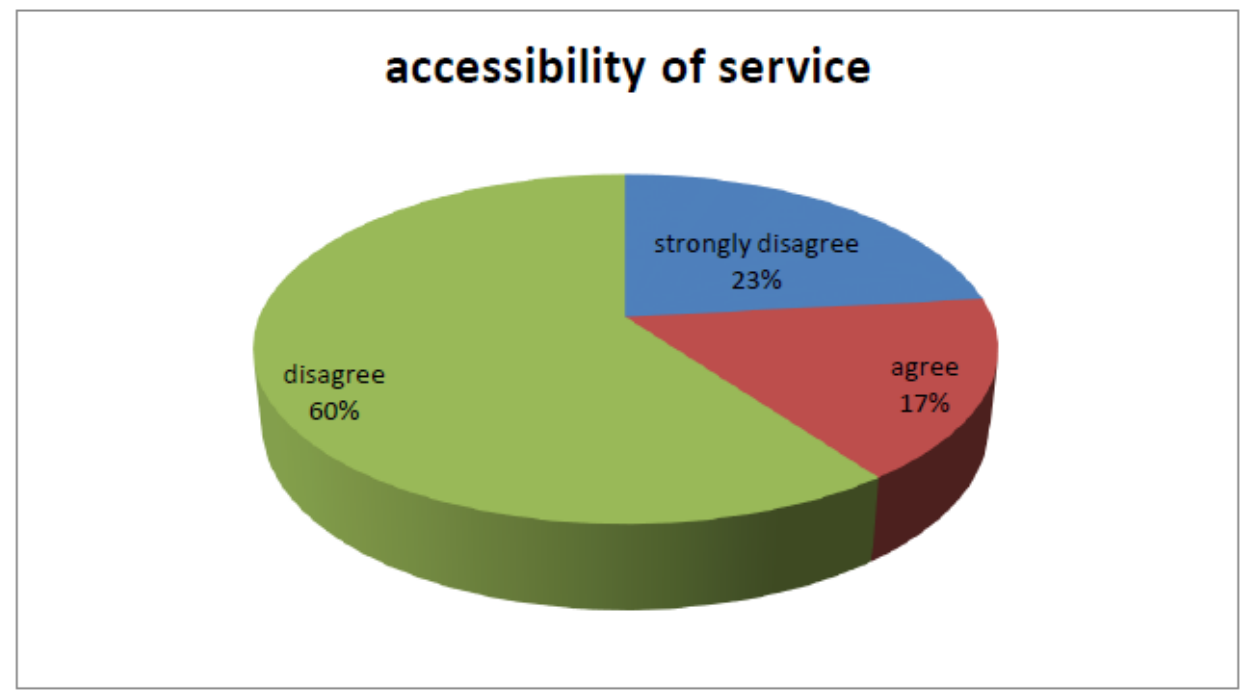

Source: field data

Based on the data gathered from the customers of DVLA, it could be deduced that most of the customers of the firm are not satisfied with the service delivery of DVLA. For instance, 18 respondents representing 60\% are not satisfied with service with regards to accessibility. Most of these customers stated that, it takes them a longer time before officials of the firm attends to them. Moreover, $68 \%$ of the customers also complained that, they had to spend the whole day at the office before their picture could be taken for a new license. Also, $52 \%$ of the customers also added that, it could take them almost 2-3 hours before having access to their data due to the fact, their data had to be searched manually. This implied that, the organization lacks electronic display of customers' data. Additionally, one particular customer stated that "I have passed through all the procedure of acquiring a new license, but they are telling me today that they cannot find my documents, so I have to go through the process again".

\section{Challenges facing DVLA in service delivery}

Secondary data gathered from officials within the procurement department and the printing department on the challenges DVLA faces on effective service delivery, particular with the issuance of driver's license card. Based on the data gathered from the respondents at the printing department, they stated that the organization uses eight printing machines, responsible for printing all driver's license card to all ten regions in Ghana .The officials added that most of these machines are obsolete and not in good condition, and currently only two of the printers are serving the entire country. They further explain that, due to the large number of people who request for new license card and replaced of their expired card, it makes it very difficult for the organization to meet it deadline, hence resulting in poor customer service.

Furthermore, when officials at the procurement department were consulted on why they have not replaced the broken machines, they also added that there has been an advertisement published in the daily newspapers, but no suppliers have been able to meet the requirement of DVLA procurement policy. The officials added that, they recently received one supplier from South Africa, but they are working towards it.

Moreover, another challenges the officials vaulted out was the high cost of raw materials for the card production and printing. "in some cases, these materials have to source from remote locations and inflated with currency depreciate and taxation, making it very expensive", as stated by one of the officials. Moreover, they further explain that the challenge is been compounded by lack of sound financial backing which could enable the plastic card to be stock in bulk materials, which will enhance cost cuts.

Additionally, another challenge mentioned is a third-party challenge. DVLA is in contract with a printing press that prints the driver's license card. According to statement from officials DVLA, it 
takes a longer time for this printing press to deliver the request of DVLA. They further added that, when most of the cards are delivered, it come with fault, for instance, an applicant surname can be change to another and distorted images of some of the picture.

\section{Recommendations and conclusion}

\section{Summary of the major findings}

Discussion on the summary of the finding is based on the research objectives which assess the analysis of the procedures involved in the issuance of driving license. Based on the data gathered at the firm, an applicant must be above18 years and must have attended an accredited driving school. Afterwards, the applicant is sent to a licensing officer for a driving test. After a successful pass, the applicant is given a certificate of competency, before proceeding to complete the driver's license application form. After application, the applicant writes an examination and goes for an eye test, where he/she is issued with a learner's permit for a period of three months to test his/ her eligibility to drive on the road, after passing the exams and the eye test.

Another objective is to identify weakness in delays associated with the issuance of license. Based on the data gathered from the respondents, out of the eight available printing machines for the printing license cards, only two of the machines are in operation, which makes it difficult for the organization to meet its three months deadline for collection of license cards. Another finding was the challenge of the third party. DVLA had contracted a printing press that prints the details of applicants on plastic cards. It was found that when this third party submits the cards, the information that are displayed on the cards are distorted there by creating the delay in the issuance.

Furthermore, there is the issue of establishing the trend analysis in the issuance of the driving license. Based on the data from the regional office of the firm in Accra, 14,368 customers registered for a test to acquire a driver's license and out of these customers, 8138 passed the examination and were issued with a driver's license in 2015.

Conclusively, the trend of driver's license issued particularly in Accra follows a steady trend where it rises and falls within intervals. More applicants register for the exams and only a few are able to pass for the acquisition of the driver's license.

The last objective was to determine the satisfaction level of customers with regards to DVLA customer service. Based on the data gathered from selected customers, the satisfaction level of customers was not encouraging. Most customers stated that it took them longer periods before they were attended to. Also, some of the customers were of the view that the service been render by the firm is unreliable which were agreed by $66 \%$ of respondents. In all, majority of respondent were not impressed by the way and manure the company transact it business and as such if there was another competitor, they could have opted for them.

\section{Conclusion}

The research seeks to focus on analyzing the procedures involve in the issuance of driving license at DVLA. The Driver and vehicle Licensing Authority (DVLA) is a semi-autonomous public sector organization under the Ministry of Transportation that promote good driving standards and establish methods for the training and testing of driving instructions and drivers of motor vehicles and riders of motor cycles and the issuance of driver's license in the country. In that view, DVLA is endorsed as the only official firm with the purpose to support high-quality driving values and road worthy vehicles. Its task also comprises of ensuring the safety of vehicles and to provide other related factors that promote effective driving and reduce the rate of accidents on the road. Of recent, there have been a lot of road accidents in the country, as a result of poor driving practices. Report from the Ministry of Transport states that there have been almost 3000 fake driver's licenses that were confiscated by DVLA officials in Accra.

This situation could be attributed to the cumbersome procedures involved in the acquisition of driver's license. A driver's license allows the holder to drive a moped, some agricultural equipment and all-terrain vehicles as well as cars. Upon passing the respective test for each stage of the system, the successful applicant is issued a temporary driving license to begin driving immediately while their permanent license is been prepared for collection within a specified period of time (Fitcher,2000). the 
permanent license contains a unique identifying number, date of birth and photograph of the holder. Most driving licenses are issued by the state agency like DVLA for Ghana and Britain.

\section{Recommendations}

Based on the summary of the finding and conclusions, the following recommendation are made;

- Managements of DVLA should ensure effective customer service, instead of the long procedure involve in acquiring a license. the firm should establish their own driving schools so that new applicants seeking to acquiring driving license will rather attend instead of attending driving schools which are not accredited.

- In connection with driving schools, the company should ensure proper supervision and ensure that the schools meet all requirement necessary for operating a driving school. The company should ensure that all driving instructors in driving schools have at least 5 years driving experience.

- The organization needs to acquire new printing machines for their operations and allocate each region its own printers that will serve that region. DVLA should make each region enquired enough to handle its own operation which should be monitor from headquarters.

- The company should find out why a large number of applicants fail their exams but yet since find a way of getting their driver's license through the assistance of middlemen 'goro boys'.

- Lastly, it is recommended that, management of DVLA train their employees in the area of customer service, since most of the customers complain about the way and manner employees handle them when they have an appointment with them.

\section{Acknowledgements}

I owe the success of this study to the following people or groups of people and to whom I am very grateful:

- God, almighty for wisdom, physical, spiritual and mental support.

- Dr. Patrick Baah Acquah, Mrs. Seeda Willson and Mr. Emmanuel Freeman for their untiring support at all times.

- A host of family and friends who through their encouraging words geared me this far.

- The host of employees from DVLA and clients who willingly accepted and honored my call to contribute to the study, I say God richly bless them.

- All authors whose materials and theories were reviewed.

\section{References}

[1]. Dioff (2001) IFLA Licensing Principles. Approved by IFLA's Executive Board. March, 2001.

[2]. Erling, s., Anderson, D.B., Svien, A.J., and Money, A.H, (2006). "Exploring project success". Baltic Journal of Management, vol. 1ssue 2pp. 127-147.

[3]. Kshama. R. The Basic Principles of Project Management. ISEB Cerified corporate. UK.

[4]. Kumar, R. (2011). Research Methodology: A step-by-step guide for beginners. $3^{\text {rd }}$ edition. London: Sage publications.

[5]. Laslo (2010) Project Portfolio Management: An integrated method for resource planning and scheduling to minimizw planning: International Journal of Project management.28(6):609-618.

[6]. Murphy A \& Ledwith A (2007) Project Management Tools and Technique in high-tech: Enterprise Research centre, Universituy of Limerish, Limerish, Ireland.

[7]. Roy, P. (2007) Self- Management and the future of software Design. Proceedings of the $3^{\text {rd }}$ International Workshop on Formal Aspects of Component Software (FACS 2006), electronics Notes in Theoretical Computer Science, Louvain-la-Neuve, Belgium, vol.182, pp201-207.

[8]. Sanders, M., Lewis, N. K., Philip and Thornhill, A (2009) Research Methods for Business students. $3^{\text {rd }}$ Edition. Harlow, financial Thesis/Prentice Hall London.

[9]. Shults. R.A \& Ali (2010) Graduated Driver Licensing Research Review; Motor Vehicle Safety Winnable Battle. Morbidity and Mortality Report. USA.

[10]. Smit, P.J. \& Cronje, G.J. de J. 2002. Management principles: A contemporary edition for Africa. 3rd edition. Cape Town. 
DOI: 10.21522/TIJAR.2014.06.01.Art006

ISSN: $2520-3088$

[11]. Steyn, H. (Ed.). 2012. Project management: A multi-disciplinary approach.3rd reviewed edition. Pretoria Daily Mirror [Kampala]. 25 $5^{\text {th }}$ June (2009). "Driving Permit Deal: URA Wants Firm to Prove Tax Exemption".

[12]. New Vision [Kampala]. 29 ${ }^{\text {th }}$ March (2009). "Change of Driving Permits Leaves Applicants Perplexed". 


\title{
Organizational Economics, the Firm, \& the Entrepreneur: A Motivation for the Emergence of the Entrepreneur as Coordinator of Organizational Resources for Firm Success
}

\author{
Article by Chilumba K. Bwalya \\ Ph.D. in Management, Texila American University \\ E-mail: bwalya2ck@gmail.com
}

\begin{abstract}
Organizational theory and organizational economics both acknowledge the existence of the firm; research about the firm, and the organization of work and people followed the path of tracing responsibility, ownership, control, and the dispensation of the unit of work to create value for the owner otherwise referred to as investor/entrepreneurs and or the owner's shareholders. In attempting to appreciate organizational economics, we discover that it actually is linked to define departments and divisions in the organization, resource allocation, the role hierarchy and control, the important role of contracts in the field, how decisions happen and where they occur from in an organization.

This research then leads to further understanding of organizational configuration which describes the way an organization is organized structurally and how their approach of doing business is described, this school of thought has been a big consideration within management research and thinking for many years; all this synthesized and guided by scholarly wisdom then discusses; an organizational economics view of the firm as a basis for the justification of the entrepreneurial organization's existence and how foundational literature in management and organizational economics can be used to create the modern entrepreneurial organization structure lead by the coordinator called 'The Entrepreneur'.
\end{abstract}

Keywords and terminologies: Firm, organization, entrepreneur, coordinator, organizational economics, management, structure.

\section{Introduction}

The way a business executes its objectives, and thrives to extend and assure its existence or indeed fail into oblivion continues to be a center of multidisciplinary research and academic thinking. The arguments for and against stretch from theory to evidence spanning many years; the central theme however is that every organization and or firms exist to achieve a particular goal and does operate in a given, specialization and business environment for that purpose.

How an organization is organized and which philosophy it chooses to optimize in order to live out its purpose is what motivates this quest of seeking to appreciate an organizational economics view of the entrepreneurial organizational approach to doing business.

Organizational configuration describes the way an organization is organized structurally and how their approach to doing business is described, this school of thought has been a big consideration within management research and thinking for many years (Payne, Short, \& Ketchan, 2008; Fiss, 2007; FoxWolfgramm, Boal, \& Hunt, 1998; Miller, 1987).

The thinking propagated therein enhances the ability of an organization to ability to be a high performer.(Meuer \& Rupietta, 2015-81) Further, (Mintzberg H. , 1992)suggests that the purpose of having an organizational configuration is for choosing the best way or approach to meeting organizational goals and objectives as the basic purpose of the organization is to meet its goals and staying true to their vision and mission (Lunenburg, 2012).

Entrepreneurial organizations are rooted in fast paced, little - to no bureaucracy and leadership centered, they are considered to be centralized decision making organizations suggests management and 
DOI: $10.21522 /$ TIJAR.2014.06.01.Art007

ISSN: $2520-3088$

organizational studies (Mintzberg H. , 1992); however this is a broad terminology which demands an exposition.

According to expository studies, Organizational Economics was considered an extension of administrative theory. (Barney \& Ouchi, 1986)in their field of study has been defined as the use of economic logic to understand the existence, nature, design, and performance of managed organizations; it studies the obstacles to coordination of activities in, between and around a firm. (Gibbons \& Roberts, 2012).

To conclude this introduction, this paper positions its prepositions and arguments to the understanding the entrepreneurial organizational approach to doing business: Analysis of the firm, relationships between firms and beyond the firm. (Williamson, 1981) has created foundational principals for the study of the economics of the organization and (Coase R. H., 1937) organization of firms for optimum strategy realization, and provides a base for further study of the entrepreneurial organizational approach to doing business for this paper.

(Mintzberg H. , The Structuring of Organizations , 1979), the choice of organizational economics as lenses for analysis is embedded in the interest to appreciate how an entrepreneurial organization interacts within itself (internal and external aspects of an organization), the external environment and what is beyond its control (a broad view of the business). According to (Gibbons R. , 2005, p. 2) Terminology the 'firm' is borrowed from the economic way of thinking and is respectfully coined to mean descriptive models of firms' 'decision making processes' (Cyert \& March, 1963).

\section{Purpose of the study}

The purpose of this study is to use organizational economic lenses to bring out the motivation for the existence of the firm, the emergence of the entrepreneurial organization and the role of the entrepreneur as a coordinator of resources in an enterprise, a firm and or organization; further motivate the role of the entrepreneur, and the relationship existing between the two as one without which the firm can survive and or pursue its core purposes or mission.

\section{Research question}

1. How did the firm come about and what was the motivation for the emergence of the firm?

2. What does organizational economics say about the firm and the entrepreneur?

3. What is the role of the entrepreneur in the firm, and or business organization?

\section{Significance of the study}

The entrepreneur is a key figure in the achievement of business success. The underlining principal for this is that the entrepreneur possesses the know how to answer social problems at a profit but there is little mention of the fact that there is need to marshal resources, coordinate the various actors in an organized way. This paper strives to get that understanding and contribute to the understanding that there exists a relationship around the firm, the entrepreneur, \& organizational economics and further present a motivation for the emergence of the entrepreneur as coordinator of organizational resources for firm success.

\section{Methodology}

In order to answer to the research questions, the methodology employed was that of a qualitative approach. Further, the paper is an exploratory study. The data contained in this paper was collected via secondary means and was extracted from leading published journals, academic papers, lectures, presentations, and videos; all from reputable sources as evidenced in the reference section of this work.

The choice to arrive at this type of study was motivated by the fact that there have been very few studies in the area of organizational economics which have linked the emergence of the firm to the role of the entrepreneur and how management and organizational studies influence the management of such a firm through different management and organizational structures and systems. 
To achieve this task, the researcher took an approach to investigate the foundational studies' in organizational economics and management \& organizational studies and compared them to recent research and trends to arrive at a link and or relationship of the studies to form the basis of the arguments.

\section{Related literature review, data analysis, and results}

This review is an approached in such a way that it attends to the needs of the research questions bringing to life early and modern studies in organizational economics and management theory and organizational studies as they relate to formation of the entrepreneurial organization and how its existence and its coordinator the entrepreneur are justifiable.

\section{Foundations of organizational thinking: organizational theories}

The study of management and organizational theory though officially and systematically related to the 1800 s is an old school of thought which is believed to have originated around the period 3000BC (Daft, 2010) to 5000BC, it is said to have been advanced by the Sumerians and Egyptians who organized governments through organizational systems at the time (Önday, 2016).

In addition, how organizations functions, how they affect the environment and how they are affected by the environment in which they operate has come to be known as the basis for the basis organizational theory. Figure 1.1 as adopted from (Growth, 2013) presents a summary of the development and evolution of management and organization theories.

Further, organizational theories are very broad naming each would be number to as many as nine (9) in total suggests (Shafritz, Ott, \& Jang, 2005), as cited in (Önday, 2016), but for the purposes of this paper they are categorized as Classical Organization Theory comprised of Scientific Management Approach (SMA), Weber's Bureaucratic Approach (WBA), and Administrative Theory (AT) (Taylor, 1947; Weber, 1947; Fayol 1949); Neoclassical Theory (Roethlisberger and Dickson 1943), and Modern Organization Theory comprised of Systems Approach (SA), Scio-technical Approach (STA), Contingency or situational Approach (SitA) Figure one below elaborately breaks down the theories.

\section{Theories of the firm, and the basis for the entrepreneurial way of organizing a firm: economic and management views}

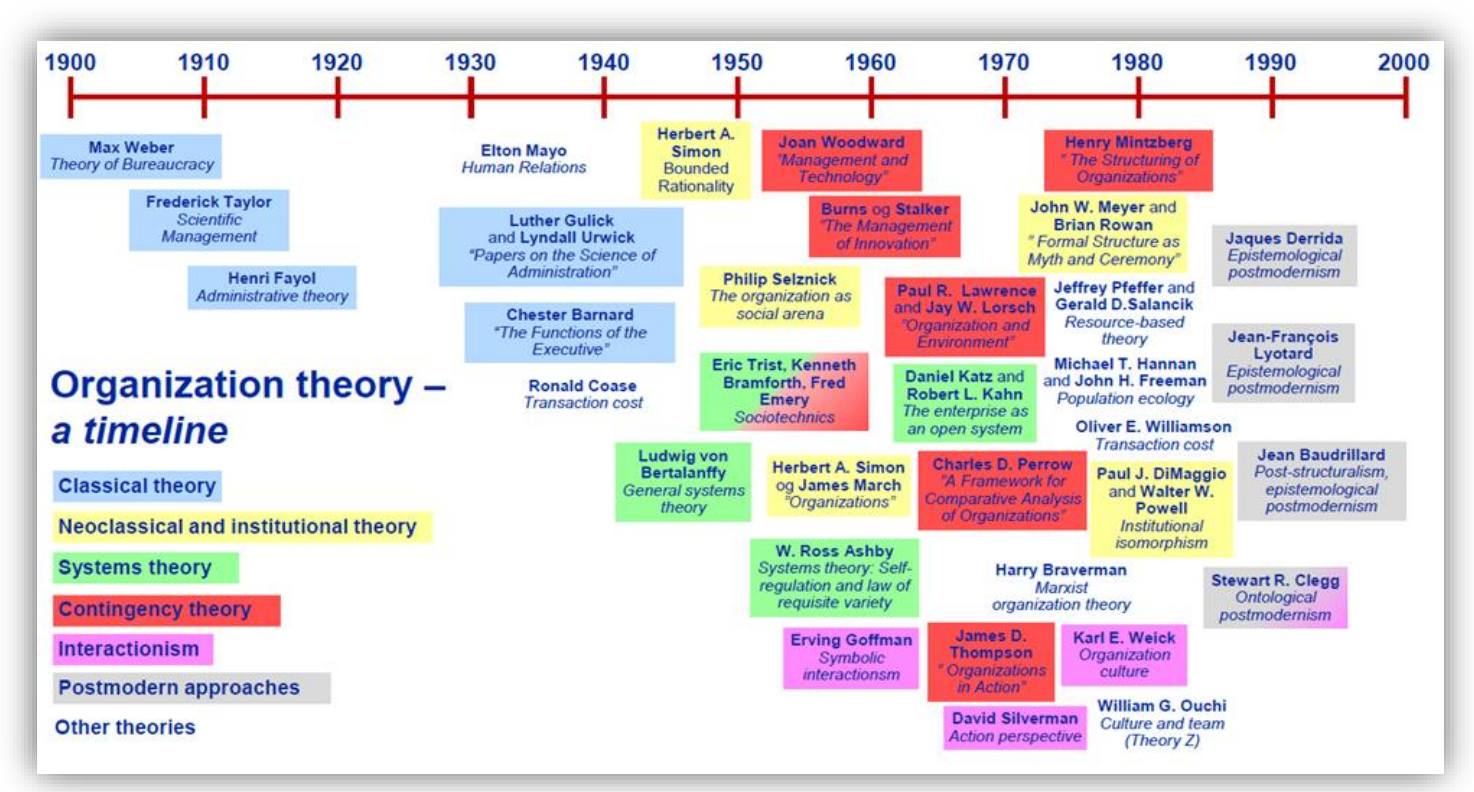

Figure 1a. Timeline and summary of management \& organizational theories 
DOI: $10.21522 /$ TIJAR.2014.06.01.Art007

ISSN: $2520-3088$

Source Adapted from - (Groth, 2013, pp. 8 - 9) Overview of theories on organization and management.

The early economic proponents of theories of the firm were referred to as neoclassical theories of the firm, this focused on the definitions of a firms' extent of existence, boundaries and internal organization (Foss, Lando, \& Thomsen, 1999), the pioneering research on these firms' dynamic and economics view were primarily research foundational studies by (Coase R. H., 1937) and (Knight, 1921) this work is further enhanced by the transactional cost approach.

The arguments that information costs are responsible for the rise of the firm and a firm is nothing, but a set of contractual obligations among factors of production encouraging voluntary exchange, and as played out in the markets to which the firms are important actors (Williamson, 1971; Alchain \& Demsetz, 1972; Jansen \& Meckling, 1976).

In specific reference to theories of the firm, the early thinking was that the consideration of the firm as to view it as one big organization of work which played at a global space and everything else remained constant and fed from it, its primary ethos was that the formulation of the firm was that of obtaining profit maximization as was the objective for the managers (Foss et al., 1999); there was no growth, no increase in the number of management expertise, incentives were not a consideration, efficiency was a given standard as there were no ways it would suffer market shock and internal organizational requirements such as organizational structure, delegation, and decision authority were not considered. Besides all this, this classical approach never limited the extent to which the firm could reach in influence and or business activity (Coase, 1937; Hart, 1999).

While the classical theories were being digested, it was between the mid-1930s and the early 1940s that a fellow by the name of Ronald Corse, ${ }^{1}$ came up with the theory of the firm, or the nature of the firm which led to the discussions of the topic of great importance to business and economic thinking called transactional cost. (Coase R. H., 1937).

Coase argued that economists needed to consider a firm in reality and not in theory. He further added that this firm interacted with other firms in the market as managed and coordinated by the entrepreneur via multiple transaction; he suggests that the purpose of the said transactions was to bring about growth as opposed to the price mechanism. Coase further stated that there was however a great limit to what a particular firm can produce in order to achieve growth and profitability.

One big consideration in Coase's theory of the firm was that of the interaction between an entrepreneurial driven firm (a firm coordinated by the entrepreneur possessing entrepreneurial attributes and behavior) and the market was not guided by a perfect market systems as suggested by Adam Smith, but was rather largely influenced by transaction costs such as the cost of obtaining goods and services in the market and the cost of holding a trade secret.(Coase R. H., 1937, pp. 388 - 389).

In further analysis of and furthering of Coase's work, his protégé Williamson (Williamson, 1981) puts across that transactional cost have a huge impact on the organization of a firm, and the more the complex these costs are managed and treated, the higher the cost of running a firm; however his work further suggested that because the simple management approach to transaction cost invite strain, then need arises for there to be different types of organizations managing varied transactional costs in firm and in the context of the market.

\section{An understanding of organizational economics key concepts and footprint}

Organizational economics has a footprint in the firm, between firms and beyond the firm. (Gibbons \& Roberts, 2012), suggests that organizational economics is used in almost all economics and management fields; it is involved with boundaries (vertical and horizontal) of the firm, management of relationships with

\footnotetext{
${ }^{1}$ Ronald Harry Coase - born 29 December 1910 and died on 2 September 2013. Coase was a renowned economist and author who in the 1930's argued that economists should study real markets and not theoretical ones, established the case for the corporation as a means to pay the costs of operating a marketplace. [3] Coase is best known for two articles in particular: "The Nature of the Firm" (1937), which introduces the concept of transaction costs to explain the nature and limits of firms, and "The Problem of Social Cost" (1960). (Nobel Media, 2014)
} 
suppliers and customers, asset ownership, coordination, and management of organizational activities, and definitions of governance systems.

Its footprint stretches further to study and understand how to define departments and divisions in the organization, resource allocation, the role of hierarchy and control, and the important role of contracts in the field, how decisions happen and where they occur from in an organization (Gibbons et al., 2012).

Information management is another critical area covered in its footprint, it deals with collection, custody, and application. Power is never a child's play activity in organizations, OE pursues the understanding of how power is achieved and exercised; rewards and impact on behavior and performance and of course the role of leadership.

All the referred to footprint areas for organizational economics are treated as questions ${ }^{2}$ that need answers; we take the words of Gibbons and Roberts in their work in the handbook of Organizational Economics (2012). The duo states that;

"How do the answers to these questions depend on the markets in which the organization operates; the strategies it adopts to compete; and the social, legal, regulatory, and technological environment ${ }^{3}$ in which it is embedded; and how do all these choices and interact and effect performance?"

\section{Organizational economics and the entrepreneurial organization, what is the link?}

Having dealt with the foundations of organizational economics views, the latest work has revealed that there actually exists a link between the entrepreneurial organization, and the concept of the firm and organizational economics.

The link between the organizational economics and the view of an entrepreneurial organization as first introduced by (Mintzberg H. , 1992)Coase is drawn from the identification of the entrepreneur ${ }^{4}$ as coordinator of resources and activities in the firm as advanced by J. B Clark, and the (Coase R. H., 1937, p. 388) manager who coordinates as put forward by Professor Night as cited (Knight, 1921) by Coase. (Coase R. H., 1937, pp. 388 - 89) Further qualified that the use of the entrepreneurs in this discourse has a link with the proponents put across by Mintzberg.

The Coasean model of the entrepreneur is at the heart of the management of the system within the enterprise exerting an authority over the command and direction of resources (Foss, Klein, \& Bylund, 2011)which(Coase R. H., 1988b) gives birth to our analysis is limited to the 'organization' the way work and activity flow is organized in an entrepreneurial way and not the concept of the entrepreneur as a person; it contains that an entrepreneurial organization fulfills its existence both in the processes and in the responsiveness to the overall business environment.

This paper observes that an entrepreneurial organization is one which is embedded in quick action, response to customers, and decision-making process lies with the entrepreneur 'coordinating' the flow of resources within the firm to respond to the larger landscape of the market; we wish to put a caveat on the fact that

\section{The entrepreneurial organization: foundations, broad structure and definitions}

(Mintzberg H. , The Structuring of Organizations , 1979, pp. 20 - 22) in his work starts out by outlining the five basic components of an organization where he has listed the strategic apex, the middle line, the operating core as the primary components being the core and undisrupted sequence of the firm, while the

\footnotetext{
${ }^{2}$ The information is covered in the introduction part of the handbook for organizational economics (Gibbons \& Roberts, 2012). The questions in the handbook are phrased in the positive sense to bring to the fore the scope of the work in organizational economics.

${ }^{3}$ The social, legal, regulatory, and technological environment are key concepts discussed in this paper to uncover how the entrepreneurial organization can be organized to respond to opportunities and challenges in the market place.

${ }^{4}$ This paper takes from (Coase R. H., 1937)'s definition on the term entrepreneur to refer to the person or persons who, in a competitive system, take the place of the price mechanism in the direction of resources.
} 
DOI: $10.21522 /$ TIJAR.2014.06.01.Art007

ISSN: $2520-3088$

techno-structure and the support as being separate from the line of authority. These parts of the organization form the building blocks for what is referred as the organizational structure and its management layers as it has come to be known today.

This paper takes interest in this clear breakdown of the organizational structure's components to build on to what Mintzberg argued that an organization had a second dimension which he referred to as the primecoordinating-mechanism ${ }^{5}$. In the prime coordination, the focus was on the definition of supervision, the work process, skill sets, standardization of output of work and mutual adjustment.

Further, (Lunenburg, 2012) using (Chandler, 2003 (1962)) and (Mintzberg H. , The Structuring of Organizations , 1979) as the foundation of his prepositions, suggest that there is a third dimension of an organization which encompasses the type decentralization employed in a particular disposition to arrive at an organizational structure, the study uses the decentralization argument as the basis for to the five organizational structures from which the entrepreneurial organization, or the simple structure stems from.

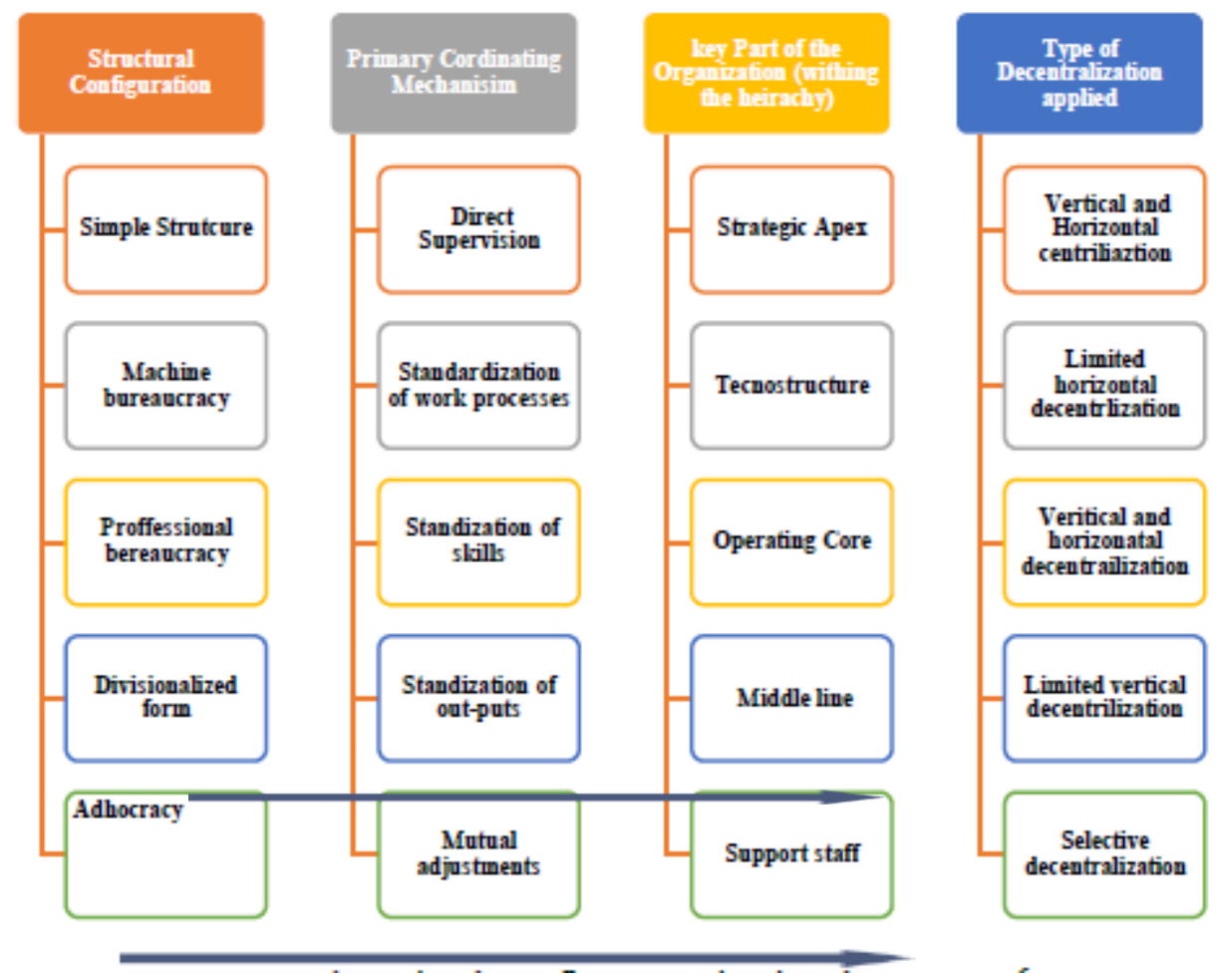

Figure 2. The Mintzberg five organizational structures ${ }^{6}$

This paper adopts the early approach of Chandler and Mintzberg for a broader application of the entrepreneurial organization with the entrepreneur at the center of coordination and resources watch outside of the firm but within the context of the market.

As quoted in the Economists, Jean-Baptiste Say, a French economist who first coined the word entrepreneur in about 1800, said: 'the entrepreneur shifts economic resources out of an area of lower productivity and into an area of higher productivity and greater yield' (Hindle, 2012). For the purposes of the analysis of the entrepreneur is referred to as a 'coordinator', this paper seeks to define term coordinator, and its meaning thereof; with that in mind, the entrepreneur as a coordinator is the initiator, implementer,

\footnotetext{
5 (Lunenburg, 2012) does an expository study of three type of dimensions of an organization from which strategy and the five organizational configurations comes from but focuses on the school context and referees the entrepreneurial organization structure as such for small organization set-ups which this paper does not agree with and is not comprehensive enough to conclude as such.

${ }^{6}$ Adapted from (Mintzberg H. , 1979)
} 
and monitor of ideas, strategic intentions, processes, investments, systems, organizational wellbeing and takes ownership of the results thereof. (The Economist, 2009)

That said, it is only right that the definition of the concept and or theory of the entrepreneurial organization start with the definition of the entrepreneur.

The European Commission, (2003) defines the entrepreneurship as a mindset, and a process to create and develop economic activity by combining risk-taking, creativity and innovation with sound management, within a new or an existing organization. It is interesting to note that every enterprise always has two types of people, those who come up with ideas and those who execute those ideas into tangible results; the entrepreneur is said to be both of the idea generator and the idea executor in most cases.(Ericksen, 2002).

Further (Meta, 2013) in their report The Entrepreneurial Organization suggest the following about entrepreneur - what it is and why it matters state ((n.d.). Retrieved March 13, 2019, from http://www.metaprofiling.com/docs/The-Entrepreneurial-Organization.pdf)

'Successful entrepreneurs are opportunists who, through their creativity, drive and vision, create economic or social value. They challenge conventional wisdom by practicing disruptive innovation innovation that creates new markets through the application of a different set of values. They change the rules of the game by questioning the status quo and upping the stake. They ask: 'why do we do things this way and how can we do better'.

Could this be the basis for the reason the entrepreneurial organization is? Is the foundation of the entrepreneurial organization a lot more embedded in the 'person's character of the entrepreneur and or in the process? Using a macroscopic broad view, the next part of the paper covers these issues.

In addition, it has been observed throughout research that the organization configurations are designed to achieve coherence and behave like a systematic flow among many parts of the structure, this is deliberate to achieve optimum capacity to meet organizational objectives and respond to the conditions outside of the firm as they act and play out in the market system. This is achieved through indulgences' of authority, information, and decision processes flow throughout the organization and the complex nature of interactions among these parts accordingly (Mintzberg H. , The Structuring of Organizations , 1979, p. 15 ) citing different theorists from behavioral scientists to contemporary organizational theories.

\section{Entrepreneurial organizational characteristics}

Researchers continue to advance the agenda for an entrepreneurial organization as one were seeking opportunities and innovation coupled with an attribute of being quick to respond to both challenges and opportunities as the key characteristics enshrined therein; the espousers of these school of thought suggest this organization is led by leadership which capable of directing performance of organizational team, groups, and or functions towards achieving of organizational goals (Meta, 2013; Renko, El Tarabishy, Carsrud, \& Brannback, 2015). The characteristics of an entrepreneurial organization therefore should possess whole or a semblance of the core requirements given in the definition.

The organization should possess a character which is embedded in a strong and clear vision, a flat organizational structure discouraging the need for bureaucratic tendencies and unnecessary long chains of commands supporting goal getting entrepreneurial leadership. Employees who are proactive, working in an environment which supports a spirit of creative and innovative mind set, opportunism is the order of the day as leadership and all organizational levels seek opportunities internally and externally of the organization; an organization were everyone without repeated instruction or reminders is ready to be involved in execution of the mission to attain the goals and objectives; collaboration holds this structure together so its encouraged at all stages of the organization, high risk tolerance is a behavior and characteristic rather than a policy and employees are empowered to make decisions in the interest of their teams' and organization as a whole; this structure is supposed to be promoting an open interactive, networking-ready work environment were individuals are self-managed and embrace inclusive culture 
DOI: $10.21522 /$ TIJAR.2014.06.01.Art007

ISSN: $2520-3088$

(Hmieleski \& Ensley, 2007; Schneider, Ehrhart, \& Macey, 2013; Kratzer, Leenders, \& Van Engelen; Shepherd \& krueger, 2002; Penn, Desylls, \& Vaughan, 2003;Denning, 2010).

\section{Entrepreneurial organizational: structure and functionality}

The foundations of the studies in structuring organizations and finding optimum fit for different type of institutional dispensations was undertaken by (Mintzberg, 1979) and where (Mintzberg H. , The Structuring of Organizations, 1981) suggested that the organization of business was based on five principal living parts of the organizations which were tasked with different responsibilities from setting the direction of the firm (apex) to execution of the goals of the firm (technical core) figure 3 below shows the breakdown.

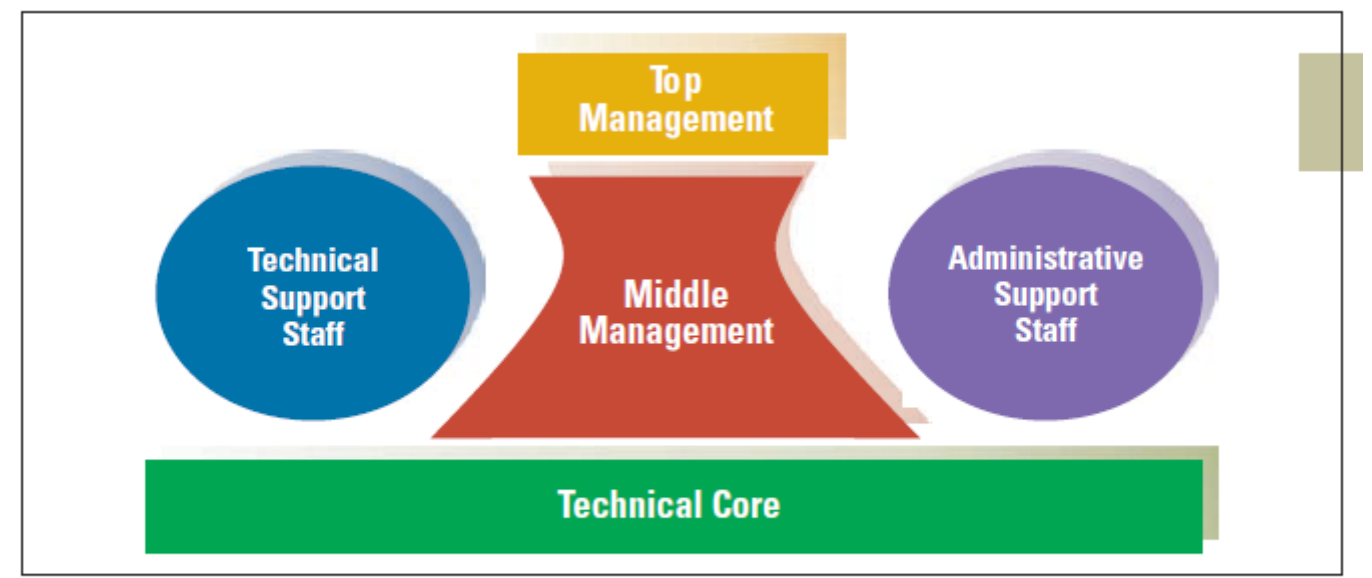

Source: Based on Henry Mintzberg, The Structuring of Organizations (Englewood Cliffs, N.J.: Prentice-Hall, 1979), 215-297; and Henry Mintzberg, "Organization Design: Fashion or Fit?" Harvard Business Review 59 (January-February 1981), 103-116.

Figure 3. Structuring of organizations: The five basic foundations of structuring an organization Adapted from:

$$
\text { (Daft, 2010, pp. } 40 \text { - 44) }
$$

The adhocracy (innovative) structure has been described as a less formalized, decentralized and more informally organized structure whose focused maintaining a pull of expertise to respond to challenges and new opportunities; the team and leadership thrives on mutual adjustments as a means of coordination and subsequently used to meet the core objective of innovation while the simple structure (entrepreneurial [Mintzberg 1979, 1992]) has been described as a structure which is managed and coordinated by direct supervision and is flexible and dynamic for purposes of responding to growth and survival demands of the business environment, this paper argues however that this type of structure is unsuited only for young and small firms (Lunenburg, 2012; Daft, 2010; Mindtools, 2018).

a) Simple (Entrepreneurial) Structure

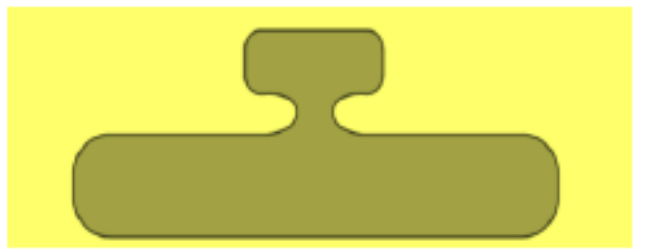

b) Adhocracy (innovative) Structure 


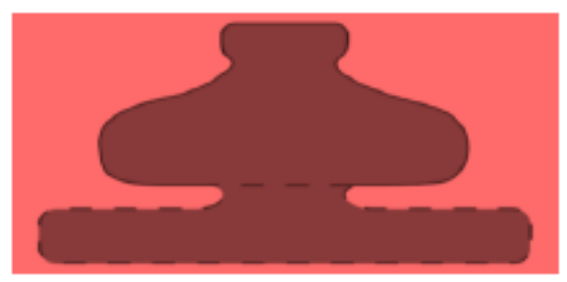

Figure 4. Simple and adhocracy organizational structures

Adapted from (Mintzberg H. , The Structuring of Organizations , 1979) as cited (Daft, 2010, pp. 40 - 44)

Keeping the submission (Figure 4) in mind, this paper proposes a combination of the simple structure (entrepreneurial organizational structure) and the adhocracy structure to be the ideal disposition of the entrepreneurial organizational structure, this is supported by the basic building blocks advanced by Coase, knight, and Mintzberg as submitted for the foundations of this paper. Figure 4 proceeds to state and exemplify the format and structural dimension would take using a four-part building blocks anchored by the entrepreneur as indicated below:

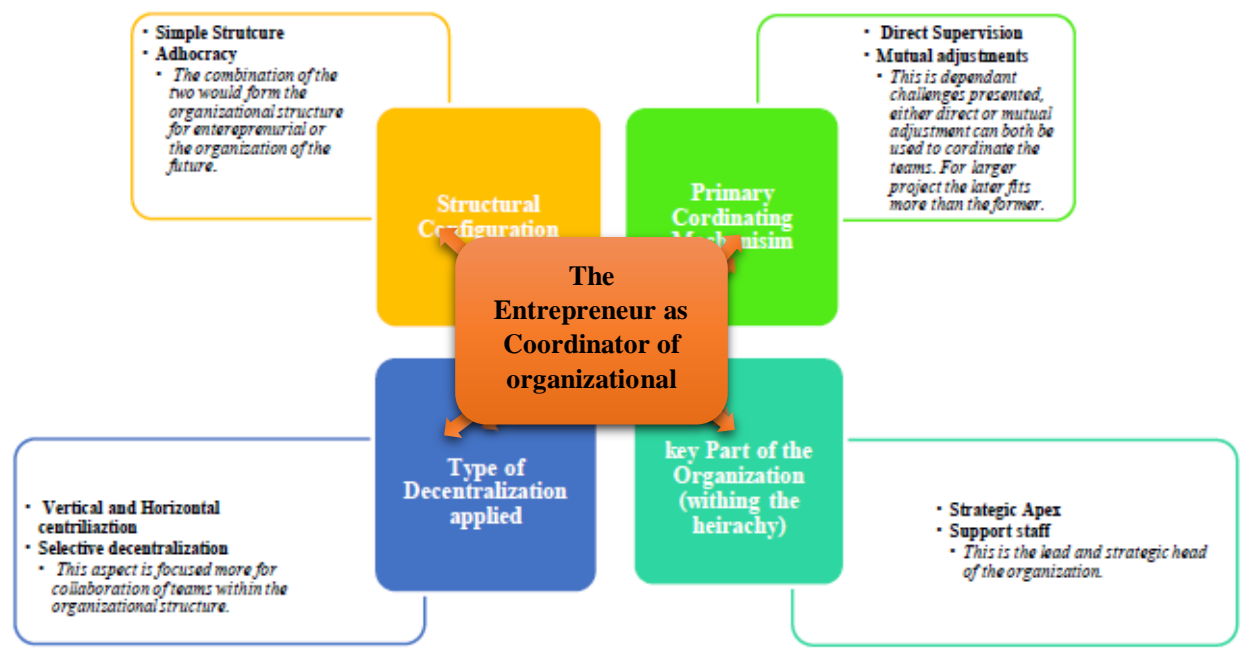

Figure 5. Adapted from (Mintzberg H. , 1992): the preposition of the modern entrepreneurial organizational structure.

i. The Entrepreneurial Organization Structural Configuration, Primary Coordination, Key Parts of the organization \& Type of decimalization.

This follows that the ideal entrepreneurial organization should be configured in a way which allows for building and operational mechanics of the organization to be supported and not suffocated. As suggested above, this can be extracted from Mintzberg' proposals of the simple and adhocracy structure this paper submits that among the five main organizational configurations studied in management, the only ones with relevant characteristics which link to the demands of an entrepreneurial organization are those are those mentioned here.

These characteristics found herein are innovation, decentralized decision making, specialized fields of operation, rapid adaptation and quick response to business environmental shocks (Mintzberg H. , 1992) as cited in (Lunenburg, 2012):

There are however two factors noticed as a major difference between the simple, and the adhocracy structures, this aspect is of larger support staff found in the adhocracy as opposed to the lean structure found in the simple structure; it has however been observed that there exists absolutely no evidence that 
DOI: $10.21522 /$ TIJAR.2014.06.01.Art007

ISSN: $2520-3088$

entrepreneurial organization are only suited for small businesses and that their support structure can never be large.

A keen interest in studying organizations such as Naspers (Honda, 2017), Apple,(Mayer \& Panmore Institute , 2017) Alibaba Group, (Walter , 2014) which started as entrepreneurial organization and are still operated and organized like one; quashes these assertions that entrepreneurial organizations must be small. In the actual sense humongous heterogeneous organizations can operate small and be strategically fitted to be responsive to the business environment. These companies and many others despite their growth have used a matrix which is decentralized yet harmonized through the strategic application of vertical and horizontal integration management style where decision power despite being originated from the apex does defuse, empowered decision making and or filter through the ranks of the structure, empowering agility, customers response and quick response to internal and external forces. The primary ethos is on empowered managers and teams.

ii. The Entrepreneur - Coordinator and allocator of resources: In this structure there exists an individual at the heart of organization who're responsible for ensuring the organizational goals are translated into both economic and financial profits through coordination; this is in consideration of the process (Olum, 2004, p. 6) of coordination in order to ensure harmony of all strategic, tactical and operational elements of the organization.

The entrepreneurial approach then uses a combination two forms of organizational approach; the simple format (entrepreneurial organization) and adhocracy (innovative organization) of direct the control \& resource allocator from the strategic apex, direct supervision on strategic projects, and the innovative approach embedded in mutual agreement and research \& development.

This structure is suited to match resources factors in the business environment. A quick response to the outside calls for a strategic fit and alignment within the internal organizational and business infrastructure on the inside of the firm.

Further the entrepreneur is tasked with a job of strategy execution mostly is achieved, operational and resources allocation to respond to market demands in the wider market space as dictated by various elements of the business environmental factors in the micro and macro sectors.

Taking advantage of the flat structure, and high-level execution and market response, it becomes easier to respond to market demands and activity. Speed and fast feedback the controlling core remain central to the success of this structure.

\section{Discussions and conclusions}

There continues to exist a lot of debate in justifying the existence of a firm and the entrepreneur as the coordinator and allocator of resources within the context of the firm; in research and practice this debate has been raging and still lacks clarity on whether the firm and the entrepreneurs (Foss et al., 2011). Despite the fundamental arguments and differences in approaching the emergence of the firm and the role of the entrepreneur thereof, this paper argued that there exists the role of the entrepreneur and further emergence of a justifiable and empirically provable actualization of the entrepreneurial organization as lead by the said entrepreneur.

Further, the study of organizing businesses and the formats which these business organizations take is based on the output of the units of production being outputted of the organization; regardless of the specialization of the organization, the basis has always been linked to desired outputs and fulfillment of core organizational mission which is interpreted into the way a firm is a) coordinated, b) the organizational context and structures it uses to respond to business environmental demands $\mathrm{c}$.) The type of decentralization it puts into place d)the final organizational configuration it will go to market with and d) how it will make decisions in response to market stimuli's and or opportunities and threats in quest to achieve its goals (Mintzberg 1992, 1990),.(Mintzberg H. , The Structuring of Organizations , 1979).

In addition, it is noticed that if the firms' existence is justifiable, and the entrepreneur using it as a vehicle to manage and reduce transactional costs is proven (McKenzie \& Lee, 2006), (Coase R. H., 1937) (Fayol, 
1949) then the need for organizing the firm emerges as a key priority but how it is organized is a choice the entrepreneur makes, and this paper submitted that at whatever stage and or the size of the business, the organization model of choice is that of which suites the mindset and behavior of decision maker and that is the entrepreneurial organization.

It has been suggested by,(Önday, 2016) that business requires a systems of relationships among functions, peoples, and the entire business environment (external and internal); in fact the coordinator thrives on the data in complied from historical, existing and future trends make judgment of what the current will need to do in order to assure stability and harmony and keep the firm and its stakeholders protected from the destruction or demise (Scott 1961); if that is the case then this paper is correct to assume that in the conversation of the emergence of the firm from the discipline of the organizational economics, it would be misjudgment to remove the entrepreneur (coordinator) and how he discharges his functions and assure firm success through the critical synthesis of the how the firm emerged and its success thereof.

The entrepreneur is a central theme in the discussion of the firm, it is hoped that the paper will provide more opportunities in research to build on its submission and inspire more research in that's studies, the entrepreneur as coordinator of resources in the context of the firm and organizational economics.

\section{Reference}

[1].Alchain, A. A., \& Demsetz, H. (1972). Production, information Costs, and economic Organization. American Economic Review, 777 - 795.

[2].Barney, J. B., \& Ouchi, W. G. (1986). Organizational Economics. San Francisco: Jossey-Bass, United States of America.

[3].Bernestien, A. (2014). Behave Yourself. Harvard Business Review (April 2014 Issue).

[4].Chandler, D. A. (2003 (1962)). Stretgy and Structure: Chapters in The History of The American Industry. Boston: MIT Press.

[5].Charan, R. (2017, May 17). The 4th Industrial Revolution. Retrieved from SunTec Business Solution - Leadership Series Confluence: https://www.youtube.com/watch?v=wwZP-Bg413s.

[6].Coase, R. H. (1937, Nov). The Nature of the Firm. Economica, 4(16), 386 - 405. Retrieved April 15, 2018.

[7].Coase, R. H. (1988b). The Nature of the firm: Meaning. Journal of Law, Economics \& Organization, 4(1), 19-32.

[8].Cooper, D. R., \& Schindler, P. S. (2014). Business Research Methods (12th ed.). New York: McGraw-Hill/Irwin,

[9].Cyert, R., \& March, J. (1963). A behavioral theory of the firm. Englewood Cliffs, NJ: Prentice-Hall.

[10]. Daft, R. L. (2010). Management. Mason, OH: South-Western, Cengage Learning.

[11]. Denning, S. (2010). A leader guide to radical management of continuous innovation. Strategy \& Leadership, 38(4), 11- 16.

[12]. Douglas, L. A., \& Marchal, W. G. (2012). STATISTICAL TECHNIQUES IN BUSINESS \& ECONOMICS (15th ed.). New York: McGraw-Hill/Irwin.

[13]. Ericksen, G. K. (2002). The Ernst \& Young Entrepreneur of The Year Entrepreneur of the Year Award Insights from the Winners' Circle. Kaplan Business, 35, 132 - 153.

[14]. Fayol, H. (1949). General and Industrial management. London: Pitman.

[15]. Fiss, P. C. (2007). A Set-Theoretical Approach to Organization Configuration. Academy of Management Review (32 (34)), 1180 - 1198).

[16]. Foss, N. J., Lando, H., \& Thomsen, S. (1999). Theory of the Firm. Encyclopedia of Law and Economics, 377.

[17]. Foss, N., Klein, P., \& Bylund, P. (2011, January). Entrepreneurship and the Economics of the Firm. SMG Working Papers, pp. 11,23,33.

[18]. Fox-Wolfgramm, S. J., Boal, K. B., \& Hunt, J. G. (1998). Organizational Adaptation to Institutional change: A Comparative Study of First-order Change in prospector and Defender Banks. Administrative Science Quarterly (43(1)), 87 - 126.

[19]. Gibbons, R. (2005). Four formal (izable) theories of the firm. Journal of Economic Behavior \& Organization, $58,200-245$. 
DOI: 10.21522/TIJAR.2014.06.01.Art007

ISSN: $2520-3088$

[20]. Guest. (n.d.). Retrieved March 11, 2019, from https://epdf.tips/entrepreneurial-learning-conceptual-frameworksand-application-routledge-advance10607.html.

[21]. Gibbons, R., \& Roberts, J. (2012). The Handbook of Organizational Economics. Princeton University Press.

[22]. Groth, L. (2013, February 6). Overview of theories on organization and management. (INF5890). Retrieved April $15,2018$.

[23]. Hart, O. (199). Firms, Contracts and Financial Structure. New York: Clarefon Press: Oxford.

[24]. Hindle, T. (2012). The Economist Guide to Management Ideas and Gurus. New York: The Economist.

[25]. Hmieleski, K. M., \& Ensley, M. D. (2007). A contextual examination of new venture performance: entrepreneur leadership behavior, top management team heterogeneity, and environmental dynamism. Journal of Organizational Behavior, 7(28), 865 - 889.

[26]. Honda. (2017, May 6). Honda organizational functions. Retrieved May 2018, from Honda Motor Co.: http://world.honda.com/RandD/fandf/.

[27]. Jansen, M. C., \& Meckling, W. H. (1976, October). Theory of the Firm: Managerial Behavior, Agency Costs and Ownership Structure. Journal of Financial Economics, 3(4), 305 - 360.

[28]. Knight, F. (1921). Risk, Uncertainty and Profits. New York: Kelley.

[29]. Kratzer, J., Leenders, R. T., \& Van Engelen, J. M. (n.d.). The social network among engineering design teams and their creativity: A case study among teams in two product development programs. International Journal of Project Management, 5(28), 428 - 435.

[30]. Lunenburg, F. C. (2012, November). Organizational Structure: Mintzberg's Framework. International Journal of Scholarly, Academic, Intellectual Diversity.

[31]. Mayer, P., \& Panmore Institute. (2017, Jan 29). Apple Inc. Organizational Structure: Features, Pros \& Cons. United States of America. Retrieved from http://panmore.com/apple-inc-organizational-structure-features-pros-cons [32]. McKenzie, R. B., \& Lee, D. R. (2006). Micro-Economics for MBA: The Economic Way of Thinking for Managers. New York: Cambridge University Press.

[33]. Meta. (2013). The Entrepreneurial Organization. Metaprofiling Ltd.

[34]. Meuer, J., \& Rupietta, C. (2015-81). Qualifying "Fit": The performance dynamics of firms' change tracks through organizational configurations. Compass Working Papers, $3,18$.

[35]. Miller, D. (1987). The Genesis of configuration. Academy Management review, 12(4), 686 - 701.

[36]. Mindtools. (2018, May 6). Mindtools. (Mindtools) Retrieved May 6, 2018, from Mindtools: www.mindtools.com/pages/newsSTR_54.htm.

[37]. Mintzberg, H. (1979). The Structuring of Organizations. New York: Prentice Hall.

[38]. Mintzberg, H. (1981). The Structuring of Organizations. Harvard Business Review (59), 103 -116.

[39]. Mintzberg, H. (1992). Structure in fives: Designing effective organizations. Upper Sadle, River NJ: Prentice Hall.

[40]. Muta, C., \& Muta, C. $\quad$ (n.d.). Retrieved March 12, 2019, from http://www.academia.edu/11623910/The_Entrepreneurial_Organization_What_it_is_and_why_it_matters.

[41]. Nobel Media. (2014). Ronald H. Coase - Biographical. Retrieved April 15, 2017, from NobelPrize: <http://www.nobelprize.org/nobel_prizes/economic-sciences/laureates/1991/coase-bio.html>

[42]. Olum, Y. (2004). MODERN MANAGEMENT THEORIES AND PRACTICES. 15th East African Central Banking Course. Nairobi: Makerere University, Faculty of Social Sciences.

[43]. Önday, Ö. (2016, March 2016). Classical to Modern Organizational Theory. International Journal of Business and Management Review, Vol.4(No.2), pp.15-59.

[44]. Payne, G., Short, J. C., \& Ketchan, D. J. (2008). Research on Organizational Configurations: Past Accomplishments and Future Challenges. Journal of Management, 34(6), 1053 - 1079.

[45]. Penn, A., Desylls, J., \& Vaughan, L. (2003). The space of innovation: interaction and communication in the work environment. Journal of Applied Psychology, 4(88), 620.

[46]. PESTLEAnalysis.com. (2015, March 20). Pestle Analysis. Retrieved November 26, 2017, from www.pestleanalysis.com. 
[47]. Renko, M., El Tarabishy, A., Carsrud, A. L., \& Brannback, M. (2015). Understanding and Measuring Entrepreneurial Leadership Style. Journal of Small Business Managment, 53(1), 54 - 74.

[48]. Schneider, B., Ehrhart, M. G., \& Macey, W. H. (2013). Organizational Climate and Culture. Annual Review of Psychology (64), 361 - 388.

[49]. Shafritz, J. M., Ott, J. S., \& Jang, Y. S. (2005). Classics of Organizational Theory. Belmont, CA: Wadsworth.

[50]. Shepherd, D. A., \& krueger, N. F. (2002). An Intentions-Based Model of Entrepreneurial Teams' Social Cognition? Entrepreneurship Theory and Practice, 2(27), 167-185.

[51]. Taylor, W. F. (1947). Principles of Scientific Management. New York NY: Harper.

[52]. The Economist. (2009, April 27). The Economist: Entrepreneurship. Retrieved from The Economist: https://www.economist.com/node/13565718.

[53]. Walter, F. (2014, May). Alibaba Looks More Like GE than Google. Harvard Business Review. Retrieved May 6, 2018, from https://hbr.org/2014/05/alibaba-looks-more-like-ge-than-google.

[54]. Weber, M. (1947). The Theory of Social and Economic Organization. New York: Free Press.

[55]. Wheelen, T. L., \& Hunger, D. J. (2000). Strategic Management and Business Policy (7th ed.). New York: Addison-Wesley Publishing Co.

[56]. Williamson, O. E. (1971). The Vertical integration of Production: Market Failure Consideration. American Economic Review (61), 112 -123.

[57]. Williamson, O. E. (1981, Nov). The Economic of Organization: The Transactional Cost Approach. American Journal of Sociology, 87(3), 548 - 577.

[58]. (n.d.). Retrieved March 11, 2019, from https://sites.google.com/site/organisationsoekonomik/ueber-denausschuss.

[59]. (n.d.). Retrieved March 13, 2019, from http://www.metaprofiling.com/docs/The-EntrepreneurialOrganization.pdf.

[60]. (n.d.). Retrieved March 12, 2019, from https://vdocuments.site/entrepreneurship-innovation-an-mitra-jay1.html. 


\title{
The Extent of the Zambian Government's Support in Eradicating the Challenges Faced by Early Childhood Teachers in Zambia
}

\author{
Article by Precious Lubinda \\ David Livingstone College of Livingstone, Zambia \\ E-mail: preciousnawa4@gmail.com
}

\begin{abstract}
Early childhood is a crucial period for the development of children's mental functions; hence it needs to be handled by qualified teachers who are well motivated. The purpose of the study is to highlight some of the challenges faced by ECE teachers in rural areas and how much efforts have been made by government in terms of policies, funding, curriculum and infrastructure. A case study of early childhood provision in rural areas of Mongu district of Western Province, was presented as an example of challenges in a remote rural of Zambia. Using questionnaires and observations from the visited schools, ECE teachers are faced with a number of challenges. Based on this background, ECE teachers are supposed to be qualified in order to be able to comprehend the developmental process of ECE children. The study results revealed that most administrators, teachers, had very little knowledge on ECE provisions, and teachers were rarely monitored by standard officers to take stock of the ECE delivery system in rural areas. Also, among other findings, ECE teachers were overloaded with other responsibilities giving them less time to prepare adequately for their classes. The study was set to investigate challenges faced by preschool teachers in rural areas, and suggest measures that could be addressed by the government and other stakeholders to ensure that there is quality delivery of early childhood education regardless of the geographical positions of the centers. Other researchers who may be interested to verify on these challenges are free to do so.
\end{abstract}

Keywords: Early childhood education, curriculum, infrastructure, conducive environment, Policy

\section{Introduction}

Early childhood education is very vital in the development of children as it lays a foundation for future education. Early childhood education plays a role in shaping positive behaviour in children because it helps to form social cohesion and peace building. When children participate in early childhood education activity, their participation is positively associated with gains in school achievements, intelligence tests, reduced grade repetition and reduced misplacement of provisions for special education. This therefore, entails that preschool teachers need motivation in terms of conducive environment, adoption of appropriate learning and teaching materials, in order for them to deliver effectively. Equal opportunities must be provided to ECE teachers in order for them to contribute positively to the well-being of children.

In the recent past, there has been a growth in interests in early childhood education among different stakeholders, because children that are exposed to early childhood education perform fairly well and better than those who had no opportunity for the preschool leaning. Research shows that child development does not only affect the child's well-being, but also his or her capacity to contribute to the well-being of society in general. For instance, the importance of early childhood education for all children was endorsed in the World declaration on Education for All (Joimtien, Thailand, 1990) and the Convention on the rights of the Child (1998). A number of studies link ECE to increases in school readiness for primary school, and it has shown that school readiness is an important predictor of early school achievement (Forget-Dubois et al 2007).The government of Republic of Zambia has also recognized the important role of early childhood education in child development as reflected in the Sixth National Development Plan (2011-2015). The policy on education - Educating Our Future of 1996 also brings out the importance of early childhood education in building early experiences in the child. 
In addition, the policy brings out the need for early childhood education in building up "cultural capital" and to compensate for disadvantages that may arise from disadvantaged homes where reading, writing, or other education-related materials are absent (Ministry of Education (MoE 1996). There is a growing consensus among scholars such as Brimbring (2001, 2006 and 2007); and Osborne and Adic (2005) that experiences of children in their early years are very important in affecting their long term cognitive, social, emotional, physical and intellectual development. It has been shown that Early Childhood Education (ECE) can be a major input into a child's formal education. To this effect, experiences should include formal and informal education. Regarding the development of ECCE, it further noted major challenges in this sub-sector in past years: fragmented curriculum; lack of standards, monitoring and supervision; and the confinement of ECCE to pre-schooling instead of offering a more comprehensive learning experience (Kamerman, 2006).

\section{General objective of study}

The main aim of the study was to enlighten both public and private schools' owners on the importance of reducing challenges in early childhood education in order to allow effective delivery of education and develop interest in the young children.

\section{Specific objectives}

The study set out:

- To investigate the challenges affecting Early Childhood Education teachers in rural areas of the Western Province of Zambia.

- To determine the extent of government's support in eradicating the challenges faced by early childhood teachers in rural schools in Zambia.

- To examine the effect of lack of proper infrastructure in the provision of early childhood education in rural Zambian schools.

\section{Statement of problem}

The extent of the Zambian government's support in eradicating the challenges faced by early childhood teachers in Zambia such as infrastructure, teaching materials, over enrollment and long distances to schools.

\section{Rationale of the study}

The study was set to investigate the challenges faced by preschool teachers in rural areas of Zambia, as well as the extent to which the government has provided support to ensure that there is quality delivery of early childhood education in rural areas.

There are numerous challenges faced by early childhood education teachers in rural areas of Western Province in Zambia. These problems have proved to be a menace towards the provision of early childhood education in various areas. However, not much has been established in terms of the extent of government's support in eradicating the challenges faced by early childhood teachers in rural areas.

\section{Literature review}

Early childhood is a crucial time period for the development of children's mental functions. This development, including the emergence of language, motor skills, psychosocial, cognitive, and learning abilities, is now known to be greatly influenced by exogenous factors, including the educational environment to which a child is exposed during the first 6 to 8 years of life (Bowman, Donovan and Burns, 2001).As regards benefits of early childhood education in Zambia, children that are exposed to early childhood education perform fairly well and better than those who had no opportunity for the preschool learning. In terms of inclusiveness of schools for early childhood education in Zambia, Despite government of the Republic of Zambia's effort and implementation of early childhood education, the provision of learning and teaching materials were not visible or catered for in any of the developments, very little if anything was happening to ensure that enough learning, teaching and infrastructure benefits the young children and teachers. The Public Health (Drainage and Latrine) Regulations makes it mandatory for any owner or occupier of schools to provide proper and sufficient latrine accommodation for girls and boys. (GRZ, 2009). This inability to support such provisions can 
be seen from several factors such as; absenteeism of children from school, lack of motivation on teachers, poor performance by children.

Children's sense of independence is supported when they can confidently and competently use equipment and when space and materials are adequate so that they can see what is available and make autonomous choices. This is in line with what Shepard and Eaton, (1997) states that children are more productively in activities when the purpose of classroom space is clearly defined and when materials are developmentally appropriate.

The early childhood environment should support the development of children as such this eases the teacher's burden. The early childhood environment must be spacious, with a lot of play materials for both indoor and outdoor activities. When there are enough learning and teaching materials, the school becomes relaxing, stimulating, exciting, thought provoking and challenging for the learners. Dodge (2004), asserts that a conducive environment enhances both fine and gross motor development through a range of appropriately challenging equipment and materials. This therefore, means that the teacher will not struggle to make children develop physically. The materials and equipment will provide the platform for learning. The teacher's role will be to facilitate and give guidance to ensure that children are safe.

'Free Education Policy' that was passed on by his excellence late former president Micheal Chilufya Sata (2012) who allowed enrolment of children without paying fees of any kind and attending school without uniforms can be seen as the government's effort to eradicate difficulties in accessing early childhood services.

The MoE states in its Strategic Plan 2003-2007 that Early Childhood Care and Education is an integral part of basic education, especially in the rural areas. The ability of many early childhood programs to provide high-quality services is in jeopardy because they lack sufficient resources to fully cover the costs of quality (NAETC, 1995). Lack of play materials and space for children leaves teachers more stressed because their learners seem not to enjoy learning and develop appropriately. Bredekamp \& Copple, (2010) alludes to play as an important vehicle for children's social and cognitive development, as well as a reflection of their development. Foundational skills impact the child's success in communication and language development, peer relationships, social adjustment, school success, and quality of life as an adult. When they are denied access to play material and adequate space, their interest and development seem to crumble. Teachers who handle these early childhood classes feel frustrated because their efforts are not seen such as holistic development due to limited space and lack of appropriate teaching and learning materials. (Heckman (2011).

Most early childhood environments in western province were generally not spacious enough, with no play materials for both indoor and outdoor activities. Very few schools had play parks and sizeable classrooms. Enough learning and teaching materials, makes the school to become relaxing, stimulating, exciting, thought provoking and challenging for the learners. The absence of all these facilities poses greater challenges to the teachers. (Prinsloo, 2005).

\section{ECE teachers' challenges}

\section{(a) Lack of infrastructure in ECE centers}

ECE teachers face common challenges in almost all areas. Most schools lack basic resources such as stationery, work cards and games posing a further challenge to the teachers and impacts negatively on the learners. In most cases, preschool teachers have to be creative in order to come up with these learning materials. A conducive environment also enhances children's self-esteem when it is designed with their needs and development in mind. The physical environment has a strong impact on both young children's learning and development. Environments that are well-designed will allow children to explore, give them a sense of control and will allow the children to engage in focused, self-directed play, and the social interaction which are meant to develop various skills, positive attributes and values. This is in line with Froebel (1985) who stated that play has a positive impact on students in their development; therefore, it should be a large part of the curriculum in schools. Pre-school teachers in the rural areas could be affected by lack of infrastructure. Infrastructure refers to the basic systems and services that are needed in order to support an economy, for example, transport and communication systems and electricity and water supplies: Early childhood education is very important and hence requires support 
from all stake holders. Education infrastructure includes suitable spaces to learn. This is one of the most basic elements necessary to ensure access to education. School classrooms are the most common place in which structured learning takes place with groups of children. (MOE, 1996).

While learning also takes place in a variety of different types of spaces - tents, temporary shelters, plastic sheeting, shade of trees, places of worship, people's homes, and so on-families and communities expected formal education to take place in classrooms that were designed for safety and comfort. Indeed, infrastructure plays a big role in the provision of early childhood education. When centers have poor infrastructure, children's movements are restricted both inside and outside the classroom, hence reducing active participation from young children. (Biber, 2006).

\section{(b) Lack of play parks}

Apart from learning materials, most preschools in the rural areas need to be furnished with play parks. Children need to be accorded chance to play outside. When children are able to select what they learn, they will be more engaged and able to attain the information. "Play allows young children to select their learning, especially if it facilitates their attainment of a broad range of developmental goals; therefore, it must be a vital component in the early childhood education curriculum" (Saracho, 2012).

Table showing the different resources obtained in rural and urban areas

\begin{tabular}{|l|l|l|}
\hline Items & Rural ECE centre & $\begin{array}{l}\text { Urban ECE } \\
\text { centre }\end{array}$ \\
\hline Swings & Not available & Available \\
\hline Desks & Only a few available & Available \\
\hline ECE classrooms & $\begin{array}{l}\text { Rooms without doors or } \\
\text { glass panes }\end{array}$ & Normal classrooms \\
\hline Toys & Not available & Available \\
\hline Mattresses/beds & Not available & Available \\
\hline Play parks & Not available & Available \\
\hline Outdoor equipment & Few and in bad shape & Available \\
\hline Flushables & Pit latrines & Available \\
\hline
\end{tabular}

Teaching younger children at preschool can take more work than it would on the primary level. Their motivation and desire to learn will largely depend on the availability of fascinating materials, which will require the teacher to be creative. The preschool teacher will be burdened with helping the preschooler in the foundation necessary for future academic success. Play stimulates children's physical, socio-emotional and cognitive development. Teachers who are not ECE trained may have difficulties on how to blend local knowledge such as popular folklore into children's activities and may not be well equipped to create a welcoming environment that stimulated creativity. They may also lack the skills to establish good communication with the children's parents. For children aged zero to six, learning should be a fun process, and educators must have the skills to guide the process. This is in line with (Ginsburg, 2013) who stated that play is important to healthy brain development. And so, applying these can help distinguish play from work, routines, rituals, and play-related behaviors like exploration and imitation.

\section{(c) Lack of assessment tools}

Another challenge was that of not having the right assessment tools for the preschool children. Assessment is the systematic process of gathering relevant information so that legal and instructional decisions are arrived at (Sternberg, 1998). Child assessment is an attempt to find out what a child can do and how he/she does it, and also to realize the effectiveness of the teacher. After all, teaching and learning are reciprocal processes that influence each other and only through assessment can it be determined how well the teacher was teaching and how well the student or child was learning (Kellough \& Kellough, 1999). Information on assessment helps in planning a curriculum to meet the child's individual needs. Assessment occurs within the context of everyday experiences; beginning with the information and observations shared by family members. As the child moves from home to the preschool, assessment continues as teachers and other staff members observe and record behaviours 
throughout the day. These systematically collected observations inform instructional practices about how to support children's strengths and abilities and provide the foundation for meaningful parentteacher conferences about a child's progress. An assessment tool with a clear protocol that measures children's progress in all learning domains is critical. Assessment tools such as Child Development Assessment Tool for Zambia (CDATZ) should be used.

Poverty is another issue that affects the delivery of early childhood education. When truancy among children is high, teachers may be required to repeat certain topics to make the children catch up, which would be an extra job for teachers. This is in line with what Joubert (2010) alluded to a situation of poverty in South Africa, despite government efforts to relieve adversity, poverty in rural areas was still rife and poor education still failed to lift people out of it. There is nothing frustrating to a teacher than poor performance of his learners. The impact of poverty and illiteracy on the development of rural children must be acknowledged and addressed. Many rural children lack basic resources, and without them, effective learning and the development of effective writing skills will continue to be hampered. The challenge of poverty breeds a number of factors that are detrimental in the delivery of education. (Nussbaum, 2010).

\section{Methodology}

Data was collected from four (4) schools with ECE centers in Mongu district, by the use of oral interviews and questionnaires. The researcher personally visited the selected schools to collect data. A sample size of four participants namely; the head teacher, one senior teacher, one ECE teacher and one parent from each school under research were interviewed. Each respondent was interviewed separately and anonymity was upheld during the process.

\section{Analysis of the research}

The challenges faced by ECE teachers in rural areas may not be the same in township schools. Though the number of schools visited may not represent the whole western province, the responses obtained gave a clear picture of what was prevailing on the ground. Some Faith Based Organizations (Catholics) supplemented government efforts but only schools in the towns benefited from the support because some places in the rural areas were impassable, and even when support was given, it was like a drop in the ocean because the schools were many. This is in line with (Heckman 2000) who echoes the need to support early childhood education in rural areas where he stated that "We cannot afford to postpone investing in children until they become adults, nor can we wait until they reach school agea time when it may be too late to intervene." Learning is a dynamic process and is most effective when it begins at a young age and continues through to adulthood.

The research revealed that the teaching methods in the curriculum were not applicable to some of the rural ECE centers due to limited space and unavailability of man power. Standing (1957) explained that the environment should exhibit the following characteristics, free from harmful objects, spacious with appropriate playing instruments. Where these facilities are not available, there can never be quality education.

The curriculum therefore should be flexible to the environment. If we were to attain the sustainable goals, the issue of quality education must be made available to all schools regardless of locations and teachers, learning and teaching materials must be distributed equally.

\section{Research findings}

Lack of proper infrastructure is a challenge emanating from this research which has a telling effect on the provision of early childhood education in Zambian schools. Most schools visited were grass thatched and made of mud and pole. This unpleasant situation which was equally lamented by the former Minister of Education Dr. John Phiri that out of 518 grass thatched schools in the country, 149 are in Western Province. (MOE 2013). This research has found that the situation has not changed, meaning that there has been less government effort in eradicating this challenge. In addition, the ECE centers are faced with lack of running water for proper sanitation as characterized by the absence of flushable toilets and the influx of ventilated improved pit latrines (VIPs). It is clear that the nature of toilets available in the ECE centers in Mongu district are not safe for young children at preschool. No 
DOI: $10.21522 /$ TIJAR.2014.06.01.Art008

ISSN: $2520-3088$

effort is seen to have been made by government in order to curb this unsafe situation for learners at preschool level.

Equally, the need for play facilities which are conspicuously absent in ECE centers cannot be overemphasized. This clearly demotivates the learners and renders the teacher's work very difficult has he or she has to find alternative means of motivating the learners, a thing which is difficult to do in rural areas where there are generally no recreation facilities.

Teaching methods advanced by the curriculum leave much to be desired as they tend to be inapplicable in most rural schools. Very little has been done by government to resolve this challenge as the recent curriculum reform was only for the higher grades.

Lack of proper infrastructure in ECE centers in Zambian schools has also proved to be a hindrance to teacher retention in rural areas as most of them could not cope with rural life, resulting in poor teacher-pupil ration in schools such as Sefula, Malabo, Mawawa and Mulambwa. Unfortunately, government has not deployed enough teachers to these rural schools, while urban schools have been flooded with teachers.

The lack of ECE teachers also entails that the teachers have to handle more than one class, thereby causing a serious gap in the efficient delivery of ECE services as it calls for more time to plan and execute. This extra burden seems not to be lessened as there were lesser efforts made to motivate such teachers as could be seen in their lack of extra duty allowances.

The research revealed that the distance covered by children was so high that it resulted in high levels of absenteeism among the pupils. This increased the teachers' pressure as they have to repeatedly go back to what has been covered in order to enable those who missed to catch up with others. The long distance covered equally has an effect on the children's nutrition. Unfortunately, there are no deliberate feeding programs put in place for preschool children in the ECE centers. This aggravates the teacher's challenge as they have to find alternative means of motivating these usually hungry children to learn. This is coupled by natural causes affecting the school such as annual flooding as is the case with Malabo Primary school. Poverty and general underdevelopment of the rural areas pose a danger to the educational welfare of preschool children.

The preschool teachers evidently lacked teaching and learning materials. This challenge has a very significant bearing on the quality delivery of ECE services in schools. In this way, the value of teaching and learning materials is compromised to a very large extent in ECE centers. Needless to say, is the fact that the efforts to improve the supply of these materials have seemingly been left in the hands of the private sector. Lack of a sufficient number of textbooks was a recurring problem in most rural, if not all, primary and basic schools in Western Zambia. Due to this lack of materials, teachers struggle with the problem of engaging all students in the lesson. The lack of materials was not solely an issue for learners, but an insufficient number of teacher manuals was a problematic for teachers, as well. Preparation for classes has become a major task for most teachers in the most rural areas where means of gathering information and conducting research are difficult. This is aggravated by lack of libraries and internet access. One Deputy Head teacher noted that the challenge for teachers to provide quality instruction resulted from lack of teacher manuals.

Given the severity of over-crowding in Zambian schools, it seemed unreasonable that international aid agencies highlighted the benefits of ECE, since they often utilized studies conducted in countries with pupil/teacher ratios between 4:1 and 10:1 as their basis (Penn, 2004) which were not attainable in rural areas related to the problems of over-enrollment and large class size was the number of teachers who were employed by the government.

Early Childhood Education teachers had many challenges in rural areas ranging from poor infrastructure, lack of teaching and learning materials, transport, distances, lack of motivation of ECE teachers and poverty levels that hinders adequate participation by both parents and children. For many teachers, the poor state of their working environment reinforces their belief that society undervalues the work they do. Staffrooms were often overcrowded; the furniture were old and frequently dysfunctional and storage facilities inadequate. Cramped staffroom conditions were often cited as a reason for not accepting teachers. In some schools, early childhood children had no permanent classroom, instead they are made to learn from offices or they were made to shift from one classroom to another. This in itself demoralized the early childhood teacher. 
Over enrolment in government pre-schools was a big challenge because most parents could not afford high fees charged by private preschools and hence the high numbers in government schools. For instance, enrolment at Mulambwa Primary school in a reception class was 58, while at Unique international (private) in a reception class was 26. Larger numbers of children per teacher revealed less verbal interaction among the teachers and the children. Teachers who have lower ratios in their classrooms are more sensitive and responsive to the children than teachers who had more children in their classroom (Howes, 2009). The size of children in a classroom is an important factor in providing quality care because children will be given individualized attention unlike when a teacher is responsible for a large number of children whereby the teacher will be unable to provide such attention but instead the teacher will be more concerned with controlling and managing the group. In this vain, NAEYC suggests a ratio of 10 to 1 for four and five-year-olds for Developmentally Appropriate Practices (Bredekamp \& Copple, 2010). However, most rural preschool teachers had a challenge of over enrolment in their classroom because the preschool may be the only nearer center in a particular area. When a teacher was in charge of a smaller group, they tend to interact more and become cooperative, innovative and demonstrate greater social competence (Clarke-Stewart, 2008).

\section{Conclusion}

Early childhood education teachers face various challenges in their quest to deliver quality education to young learners in Zambia. These challenges are enhanced further by poverty and underdevelopment in rural areas which serve as a litmus test on the effectiveness of the government efforts to alleviate these numerous problems faced by early childhood education teachers in their daily tasks of delivering education to the young children. The lack of adequate government support to eradicate these challenges has repeatedly been bemoaned by the researcher and other concerned stakeholders. It is in view of this that it is recommended that government scales up its efforts to improve the provision of ECE by partnering with other stakeholders from various sectors of society. This would culminate into an effective and meaningful improvement in the welfare of preschool teachers in the execution of their duties.

\section{References}

[1]. Barnett W S. (Fall/Winter). Long-term effects of early childhood programs on cognitive and school outcomes. The future of children: Long-term outcomes of early childhood programs, 1995; 5(3):25-50.

[2]. Biber, B. (2006). Early education and psychological development. New Haven, CT: Yale University Press. [3]. Bowman, B., M Donovan and M. Burns, eds. 2001. Eager to Learn: Educating Our Preschoolers, Committee on Early Childhood Pedagogy, Commission on Behavioral and Social Sciences and Education, National Research Council, National Academy Press, Washington, DC.

[4]. Bredekamp, S., and Copple, C. E. (Eds.) (2010) developmentally appropriate practice in early childhood programs serving children from birth through age 8 (Rev.ed.). Washington, DC: National Association or the Education of Young Children.

[5]. Bronfenbrenner, U. (2009). The ecology of human development. Cambridge. MA: Havard University Press. [6]. Clarke-Stewart, (2008). Predicting child development from child care forms and features. Chicago Study. In D.A. Phillips (Ed.), Quality in child care: What does research tell us? (pp. 21-41). Washington, DC: National Association for the Education of Young Children.

[7]. Cohen L, Manion L \& Morrison K. 2008. Research methods in education. 6th Edition. London: Routledge Cohen L, Manion L \& Morrison K. 2008. Research methods in education. 6th Edition. London: Routledge.

[8]. Cuffaro, H., K., Nager, N., Shapiro, E. K. (2000). The Developmental-Interaction Approach at Bank Street College of Education. In J. L. Roopnairine \& J. E. Johnson (Eds.) Approaches to early childhood education ( $3^{\text {rd }}$ ed.) Upper Saddle River, NJ: Merrill.

[9]. Forget-Dubois, N., J. Lemelin, M. Boivin, G. Dionne, J. Seguin, F. Vitaro, and R. Tremblay. (2007). "Predicting Early School Achievement With the EDI: A Longitudinal Population-Based Study" Early Education and Development. 18:3, 405-426.

[10]. Froebel, Friedrich. 1895 [1985]. Friedrich Froebel's Pedagogics of the Kindergarten: Or, His Ideas Concerning the Play and Playthings of the Child. New York: D. Appleton. 
DOI: 10.21522/TIJAR.2014.06.01.Art008

ISSN: $2520-3088$

[11]. Government of the Republic of Zambia Sixth National Development Plan 2011-15. Lusaka: Cabinet Office, 2011.

[12]. Heckman, J. (2011). The economics of inequality: the value of early childhood education. Am Educ, 35(1), $31-35$.

[13]. Hong, X, \& Luo, L. (2012). Analysis of differences in preschool education development in urban and rural China from the perspective of education equity. Educ Stud, 8(5), 73-81. In Chinese.

[14]. Howes, C. (2009). Care giver behavior in centre and family day care. Journal of Applied Developmental Psychology: 4, 99-107.

[15]. Howes, C. (2010). Children's experience in centre-based child care as a function of a teacher background and adult-child ratio. Merrill-Palmer Quarterly: 43, 404-425.

[16]. Hu, BY, \& Roberts, SK. (2013). A qualitative study of the current transformation to rural village early childhood in China: Retrospect and prospect. Int J Educ Dev, 34, 316-324.

[17]. Kamerman, S. B. (2006). A global history of early childhood education and care. Paper commissioned for the EFA Global Monitoring Report 2007, Strong foundations: Early childhood care and education. UNESCO: Paris.

[18]. Ministry of Education (1996), Educating Our Future: National policy on education, Lusaka: Zambia Educational Publishing House.

[19]. Ministry of Education. (2006). Fifth national development plan 2006-2010. Zambia: Poverty reduction strategy paper. Retrieved November 13, 2008

[20]. Nussbaum, C. M, 2010, Not for profit: Why democracy needs the humanities,

[21]. Princeton: Princeton University Press.

[22]. Penn, H. (2004). Childcare and early childhood development programmes and policies: Their relationship to eradicating child poverty. Childhood Poverty Research and Policy Centre, CHIP Report No. 8. Retrieved November 14, 2008.

[23]. Prinsloo, E. (2005). Socio-economic barriers to learning in contempory society. In: E Landsberg (ed). Addressing barriers to learning: A South African perspective. Pretoria: Van Schaik. 27-41.

[24]. Saracho, O. N. (2012). An integrated play-based curriculum for young children.

[25]. Sheperd, W., \& Eaton, J. (1997). Creating environments that intrigue and delight children and adults. Child Care Information Exchange, 117, 42-47.

[26]. Yao, B. and Y. Xie. 2004. Thought on Current Situation of Kindergarten Teachers in Rural Areas, Kid Education, (7-8). 


\section{$4+\pi y^{2}$ TEXILA}

\section{AMERICAN \\ UNIVERSITY}

\section{Texila American University} Lot 2442, Plantation Providence, East Bank Demerara(Ebd), Gayana, South America.

\section{GLOBAL OFFICE}

Texila Educational \& Management Services ( $P$ ) Ltd Module 310, lii Floor, Tidel Park Aerodrome Post, Coimbatore-641014 E-mail : ejournal.assist@tau.edu.gy 